\title{
PROLYL-4-HYDROXYLASE DOMAIN 3 (PHD3) IS A CRITICAL TERMINATOR FOR CELL SURVIVAL OF MACROPHAGES UNDER STRESS CONDITIONS
}

\section{DOCTORAL THESIS}

In partial fulfillment of the requirements for the degree

"Doctor of Philosophy (Ph.D.)"

in the Molecular Medicine Study Program

at the Georg-August University Göttingen

Submitted by

Lija Swain

Born in Bhubaneswar, Odisha, India

Göttingen, May 2014 


\section{Members of the thesis committee}

\section{Supervisor}

Prof. Dr. Dörthe Katschinski

Göttingen University Medical Center

Institute of Cardiovascular Physiology

Humboldtallee 23, 37073 Göttingen, Germany

Tel: +49 (0) $55139-5896$

E-mail: doerthe.katschinski@med.uni-goettingen.de

\section{Co-supervisor}

Prof. Dr. Blanche Schwappach

Göttingen University Medical Center

Institute of Biochemistry I

Humboldtallee 23, 37073 Göttingen, Germany

Tel: +49 (0)551-395962

E-mail: blanche.schwappach@med.uni-goettingen.de

\section{Co-supervisor}

\section{Dr. Viacheslav Nikolaev}

Göttingen University Medical Center

Department of Cardiology and Pneumology

Robert-Koch-Str. 40, 37075 Göttingen, Germany

Tel: +49 (0)551-39 10965

E-mail: viacheslav.nikolaev@med.uni-goettingen.de

Date of disputation $7^{\text {th }}$ July 2014 
Dedicated to my Father 


\section{Affidavit}

I hereby declare that my doctoral thesis entitled "Prolyl-4-hydroxylase domain 3 (PHD3) is a critical terminator for cell survival of macrophages under stress conditions" has been written independently with no other sources and aids than quoted.

Lija Swain

Göttingen, May 2014 


\section{Table of Contents}

Acknowledgement viii

List of figures $\quad$ ix

$\begin{array}{lc}\text { Abbreviations } & \mathbf{x}\end{array}$

Summary $\quad$ xiii

1. Introduction $\quad 1$

1.1 Hурохіа 1

1.2 Hypoxia-inducible factors $\quad 1$

$\begin{array}{lll}\text { 1.2.1 HIF-1 } \alpha & 2\end{array}$

$\begin{array}{lll}1.2 .2 & \text { HIF- } 2 \alpha & 3\end{array}$

$\begin{array}{lll}1.2 .3 & \text { HIF- } 3 \alpha & 4\end{array}$

$\begin{array}{lll}1.2 .4 & \text { HIF-1 } \beta & 4\end{array}$

1.3 Regulation of $\mathrm{HIF \alpha} \quad 5$

1.4 Prolyl-4-hydroxylase Domain Enzyme (PHD) 8

$\begin{array}{lll}1.4 .1 & \text { PHD1 } & 10\end{array}$

$\begin{array}{lll}1.4 .2 & \text { PHD2 } & 10\end{array}$

$\begin{array}{lll}1.4 .3 & \text { PHD3 } & 10\end{array}$

1.5 PHDs targets other than HIFs

1.6 Hypoxia and myeloid cells $\quad 15$

$\begin{array}{lll}\text { 1.7.1 Hypoxia and macrophages } & 15\end{array}$

$\begin{array}{lll}1.8 & \text { Angiopoietin-like protein 2 (Angpt/2) } & 17\end{array}$

$\begin{array}{lll}1.9 & \text { Angpt/2 and inflammation } & 18\end{array}$

$\begin{array}{ll}1.10 & \text { Aim of the study }\end{array}$

2. Materials and methods $\quad 22$

2.1 Materials $\quad 22$

$\begin{array}{lll}2.1 .1 & \text { Chemicals } & 22\end{array}$

$\begin{array}{lll}2.1 .2 & \text { Buffers } & 24\end{array}$

$\begin{array}{lll}2.1 .3 & \text { Antibodies } & 25\end{array}$

$\begin{array}{ll}2.1 .4 & \text { Cell culture medium } \\ 2.1 .5 & \text { Primers }\end{array}$

$\begin{array}{lll}2.1 .5 & \text { Primers } & 26\end{array}$

2.1.6 Commercial kits 28

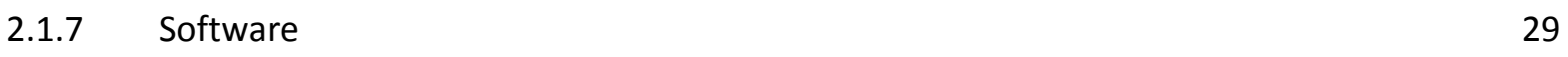

$\begin{array}{lll}2.1 .8 & \text { Instruments } & 29\end{array}$ 
2.2 Methods $\quad 31$

2.2.1 Myeloid-specific conditional PHD3 knockout $\left(\mathrm{PHD3}^{--}\right)$mice 31

$\begin{array}{lll}\text { 2.2.2 Isolation of gDNA } & 31\end{array}$

$\begin{array}{lll}2.2 .3 & \text { Polymerase chain reaction } & 31\end{array}$

2.2.4 Differentiation and cultivation of bone marrow-derived macrophages 32

$\begin{array}{lll}2.2 .5 & \text { Isolation of RNA } & 33\end{array}$

$\begin{array}{lll}\text { 2.2.6 RNA concentration measurement } & 33\end{array}$

$\begin{array}{lll}\text { 2.2.7 CDNA synthesis } & 33\end{array}$

$\begin{array}{lll}\text { 2.2.8 Quantitative real-time PCR } & 34\end{array}$

$\begin{array}{lll}2.2 .9 & \text { Protein extraction } & 35\end{array}$

2.2.10 Bradford Protein concentration assay $\quad 35$

2.2.11 SDS-Polyacrylamide gel electrophoresis (PAGE) 36

$\begin{array}{ll}\text { 2.2.12 Western blot Development } & 37\end{array}$

$\begin{array}{lll}2.2 .13 & \text { TUNEL ASSAY } & 38\end{array}$

2.2.14 Annexin V Staining $\quad 39$

$\begin{array}{lll}2.2 .15 & \text { Flow cytometry } & 39\end{array}$

$\begin{array}{lll}2.2 .16 & \text { Calcein-AM cell viability assay } & 40\end{array}$

2.2.17 Angpt|2 ELISA $\quad 40$

2.2.18 Transcriptome screen $\quad 41$

$\begin{array}{lll}2.2 .19 & \text { Statistics } & 42\end{array}$

3. Results $\quad 43$

3.1 Generation of myeloid-specific PHD3 knockout mice 43

3.2 Consequences of a PHD3 deficiency in macrophages for their differentiation and morphology 44

3.3 Consequences of PHD3-deficiency for macrophage gene expression 46

3.4 HIF-dependent target gene expression is unchanged in $\mathrm{PHD}^{\%}{ }^{-} \mathrm{BMDM} \quad 48$

3.5 Macrophage polarization is unaffected in $\mathrm{PHD3}^{\%}$ BMDM 52

3.6 $\mathrm{PHD}^{\%}$ BMDM are protected from apoptotic cell death 54

3.7 Confirming the differential expression of genes by qRTPCR 59

3.8 Angpt/2 is differentially expressed and involved in the differential apoptotic response 60

3.9 Treatment of BMDM with recombinant Angpt/2 64

4. Discussion $\quad 66$

4.1 HIF target gene expression is unchanged in $\mathrm{PHD3^{-/ }}$ BMDM 67

4.2 Macrophage polarization is unaffected in $\mathrm{PHD}^{-\%}$ BMDM 68

4.3 NFKB activity is unaffected in $\mathrm{PHD}^{-\%}$ BMDM 69

4.4 PHD3 plays a pro-apoptotic role in BMDM 69 
4.5 Loss of PHD3 affects the expression of Angpt/2 70

4.6 Loss of Angpt/2 attenuates BMDM apoptosis 71

4.7 Angpt/2 affects macrophage apoptosis 72

5. Conclusion and Outlook

6. References

7. Curriculum vitae

86 


\section{Acknowledgement}

I owe my deepest gratitude to my supervisor Prof. Dr. Dörthe Katschinski for her excellent guidance, caring, patience, and providing me with an excellent atmosphere for doing research. I extent my thanks to my thesis committee members, Prof. Dr. Blanche Schwappach and Dr. Viacheslav Nikolaev, for their helpful suggestions, comments and precious time for guiding me during my thesis work. I sincerely thank our collaborator Prof. Yuichi Oike for his willing support and experimental help during most crucial period of this thesis work. My special thanks to Hariki Odagiri for performing the experiments with Angptl2 knockout macrophages in Japan for this thesis. I am grateful to Prof. Dr. Susanne Lutz, Prof. Dr. Matthias Dobbelstein and Prof. Dr. Thomas Meyer for accepting to be my coexaminers.

My greatest thanks go to all my colleagues working at the Institute of Cardiovascular Physiology for being so supportive, understanding and always helpful. I owe a great debt to Katja Farhat for mentoring me and teaching me most of the techniques during my study. My special thanks to her for being so patient and supportive all the time. I would like to express my gratitude to Marieke for her constant help and guidance during my work. I owe my deepest gratitude to Amke for the extremely fast correction of this thesis and her valuable suggestions during the course. I would like to thank to Annette for helping me always with my tedious experiments and the extended supports she always offered. I would like to offer my special thanks to Anke, Sabine, Malanie, Annemarie, Malanie, Angelika, Steffi, Sabina, Pia, Marion and Shunmugam for the excellent working environment, constant support, help and contribution to this work.

I dedicate my thesis to my father who supported and encouraged me in my decisions and made them possible at the end. He stood beside me like a pillar during all these year and guided me with his valuable suggestions. I am grateful to him for helping me in living my dream and supporting me so far. Thanks would not be enough to express my feelings and gratitude for his contributions that he made to my life. I also owe a great debt to my mother for her emotional support, understanding and love. I would like to thank my brother Jagannath Swain and sister Rashmi Swain for taking up my responsibilities at home, when I was away doing my studies all these years and also at times for being my partner in crime. I thank to all my friends for supporting me in difficult times and for giving me the good memories to smile about. Finally, I would like to thank my husband Sabyasachi Das, who accompanied me through wonderful times over the past years and supported me with almost self-sacrificing devotion. In addition I thank my parents in law Mr. Umakanta Das and Mrs. Harapriya Das for their encouraging words during writing of my thesis when I was needed it the most. Thank you so much for being so friendly and making my journey into their lives smooth. 


\section{List of figures}

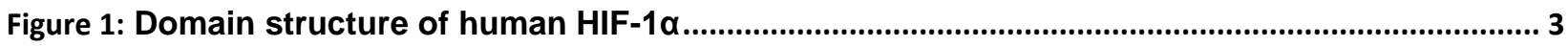

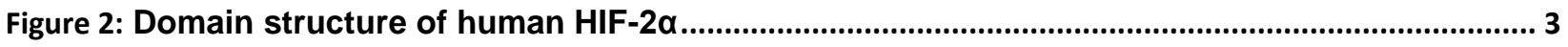

Figure 3: Domain structure of human HIF-3a

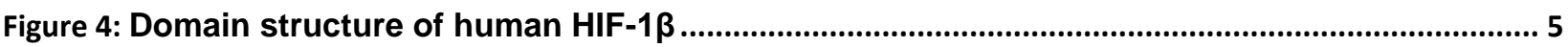

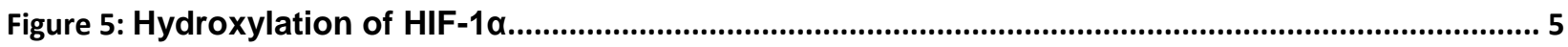

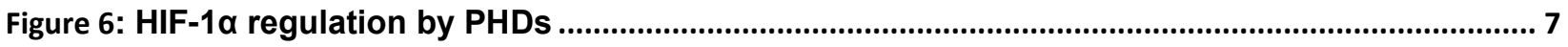

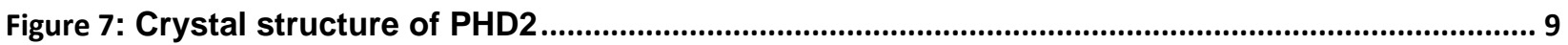

Figure 8: Myeloid cell response to hypoxia/ inflammation ................................................................... 17

Figure 9: Myeloid-specific PHD3-deficient mouse line generation scheme ............................................. 43

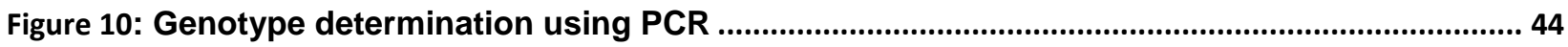

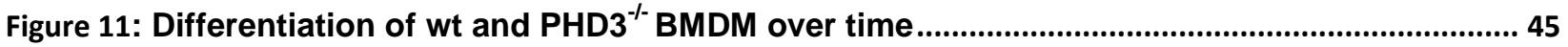

Figure 12: Morphology of wt and PHD3 ${ }^{-/}$BMDM during differentiation ................................................ 46

Figure 13: PHD3 mRNA expression of wt and PHD3 ${ }^{-/-}$macrophages................................................... 46

Figure 14: mRNA expression of PHD1 and PHD2 of wt and PHD3 ${ }^{-/}$macrophages ............................... 47

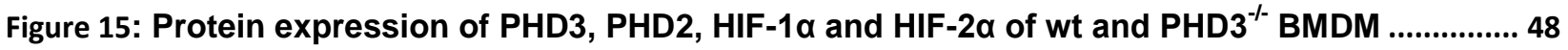

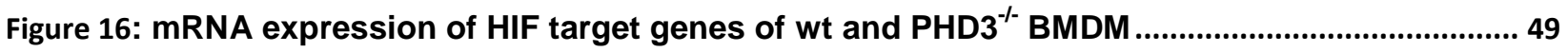

Figure 17: Volcano plot for differentially expressed genes under normoxia and hypoxia ................... 49

Figure 18: NFKB activity in wt and PHD3 ${ }^{-/ 2}$ macrophages ....................................................................... 52

Figure 19: Macrophage polarization of $\mathrm{PHD3}^{-/ 2}$ macrophages ............................................................... 53

Figure 20: IL-6 and TNFa secretion of PHD3 ${ }^{-/}$macrophages .................................................................. 54

Figure 21: TUNEL assay comparing wt and PHD3 ${ }^{-/-}$BMDM apoptosis .................................................... 55

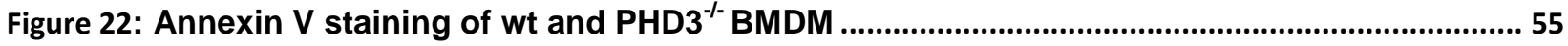

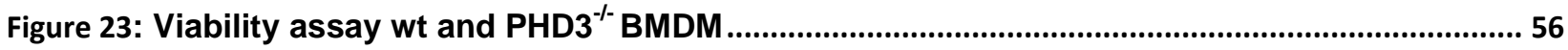

Figure 24: Annexin V assay staining of wt and PHD3 ${ }^{-/}$BMDM with apoptotic inducers treatment..... 56

Figure 25: TUNEL assay of wt and PHD3 ${ }^{-/-}$BMDM comparing normoxic versus hypoxic effects ........ 57

Figure 26: qRT-PCR analysis confirming the differential expression of candidate genes ...................60

Figure 27: wt conditioned medium induces apoptosis of PHD3 ${ }^{-/}$macrophages ..................................... 61

Figure 28: Angpt12 expression of wt and PHD3 ${ }^{-/}$macrophages ............................................................. 62

Figure 29: Angpt12 expression under the treatment of apoptotic inducers...............................................62 62

Figure 30: Angpt12 expression and secretion at protein level ...................................................................63 63

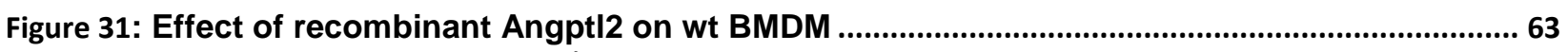

Figure 32: Treatment of wt and PHD3 ${ }^{-/ 2}$ BMDM with recombinant Angptl2 ............................................. 64

Figure 33: Expression of Angptl2 receptors in wt and PHD3 ${ }^{-/-}$macrophages ......................................... 65 


\section{Abbreviations}

${ }^{\circ} \mathrm{C}$

2-OG

aa

AhR

Angpt12

APS

ARNT

Asn

ATF

ATP

$\mathrm{Bcl}-2$

bHLH

BMDM

bp

BSA

CAMP

CD

$\mathrm{CO}_{2}$

C-TAD

DAPI

dd

DEPC

DMEM

DMOG

DMSO

DNA

dNTP

dsDNA

ECL

ECM

EDTA

EGLN

ELISA

ER

FACS

FCS
Degrees Celsius

2-oxoglutarate

Amino acid

Aryl hydrocarbon receptor

Angiopoietin-like protein 2

Ammonium persulfate

Aryl hydrocarbon receptor nuclear translocator

Asparagine

Activating transcription factor

Adenosine triphosphate

B-cell lymphoma 2

Basic helix-loop-helix

Bone marrow derived macrophages

Base pair

Bovine serum albumin

Cyclic adenosine monophosphate

Cluster of differentiation

Carbondioxide

C-terminal transactivation domain

4',6-diamidino-2-phenylindole

Double distilled

Diethylpyrocarbonate

Dulbecco's modified eagle medium

Dimethyloxaloylglycine

Dimethyl sulfoxide

Deoxyribonucleic acid

Deoxyribonucleotide triphosphate

Double-strand DNA

Enhanced luminol-based Chemiluminescent

Extracellular matrix

Ethylenediaminetetraacetic acid

Egg laying defective nine

Enzyme-linked immunosorbent assay

Endoplasmic reticulum

Fluorescence-activated cell sorting

Fetal calf serum 
Fig

FIH

Fizz

g

GLUT

HCLK2

HEPES

HIF

HRE

HRP

hrs

IFN $\gamma$

IGFs

$\lg G$

IL

iNos

$\mathrm{KCl}$

$\mathrm{kDa}$

KIF1 $\beta$

$\mathrm{K}_{\mathrm{M}}$

LILERB2

LPS

LysM

LZIP

M-CSF

$\min$

ml

mM

MMPs

mRNA

MS12

MTT

$\mathrm{NaCl}$

$\mathrm{NaOH}$

NFKB

NO

N-TAD
Figure

Factor inhibiting HIF

Found in inflammatory zone

gram

Glucose transporter

Human homologue of the Caenorhabditis elegans biological clock protein CLK-2

4-(2-hydroxyethyl)-1-piperazineethanesulfonic acid

Hypoxia inducible factor

Hypoxia response element

Horse radish peroxidase

Hours

Interferon $\gamma$

Insulin-like growth factors

Immunoglobulin G

Interleukin

Inducible nitric oxide synthase

Potassium chloride

Kilo Dalton

Kinesin-like protein $\beta$

Michaelis-Menten constant

Leukocyte immunoglobin-like receptor B2

Lipopolysaccharide

Lysozyme M

Leucine zipper domain

Macrophage colony-stimulating factor

Minutes

millilitre

millimolar

Matrix metalloproteinases

Messenger ribonucleic acid

Minisatellites 12

3-(4,5-dimethylthiazol-2-yl)-2,5-diphenyl-tetrazoliumbromid

Sodium chloride

Sodium hydroxide

Nuclear factor kappa-light-chain-enhancer of activated B cells

Nitric oxide

$\mathrm{N}$-terminal transactivation domain 


\begin{tabular}{|c|c|}
\hline ODD & Oxygen-dependent degradation domain \\
\hline PAGE & Polyacrylamide gel electrophoresis \\
\hline PAS domain & Per-Arnt-Sim domain \\
\hline PBS & Phosphate buffered saline \\
\hline PCR & Polymerase chain reaction \\
\hline PDK-1 & Pyruvate dehydrogenase kinase- 1 \\
\hline PFA & Paraformaldehyde \\
\hline Pfk & Phosphofructokinase \\
\hline PHD & Prolyl-4-hydroxylase domain enzyme \\
\hline PI & Propidium lodide \\
\hline PirB & Paired immunoglobin-like receptor B \\
\hline PKM2 & Pyruvate kinase M2 \\
\hline pVHL & von Hippel-Lindau tumor suppressor protein \\
\hline qRT-PCR & Quantitative real-time PCR \\
\hline RNase & Ribonuclease \\
\hline rpm & Revolutions per minute \\
\hline SD & Standard deviation \\
\hline SDS & Sodium dodecyl sulfate \\
\hline SEM & Standard error of the mean \\
\hline SNAP & S-nitroso-N-acetylpenicillamine \\
\hline Stauro & Staurosporine \\
\hline SYBR & SYBR green \\
\hline TAE & Tris acetate EDTA \\
\hline TCA & Tricarboxylic acid cycle \\
\hline TE & Tris EDTA \\
\hline TEMED & Tetramethylethylenediamine \\
\hline $\mathbf{T}_{\mathrm{m}}$ & Melting temperature \\
\hline TMB & 3,3',5,5'-Tetramethylbenzidine \\
\hline TNFa & Tumor necrosis factor $\alpha$ \\
\hline TUNEL & Terminal deoxynucleotidyl transferase dUTP nick end labeling \\
\hline V & Volt \\
\hline VEGF & Vascular endothelial growth factor \\
\hline wt & Wild type \\
\hline
\end{tabular}




\section{Summary}

On molecular level, cells sense changes in oxygen availability through the prolyl-4-hydroxylase domain enzymes (PHDs), which in turn regulate the protein stability of the $\alpha$-subunit of the transcription factor hypoxia-inducible factor (HIF). By using molecular oxygen PHDs 1 - 3 hydroxylate two specific proline residues thereby marking HIFa for proteasomal degradation. Among the three PHD isoforms the constitutively expressed PHD2 is the main regulator of HIF $\alpha$ stability and thus hypoxia-inducible gene expression in normoxia. PHD3 is highly induced under hypoxic conditions and serves as a negative feedback regulator. Especially PHD3 has been additionally associated with apoptotic cell death. I hypothesized that PHD3 plays a role in cell-fate decisions in macrophages. Therefore, myeloid-specific PHD3 knockout mice $\left(\mathrm{PHD}^{-/}\right)$were created and analyzed. PHD3-deficient bone marrow-derived macrophages (BMDM) showed no altered HIF-1 $\alpha$ or HIF-2 $\alpha$ stabilization or increased HIF target gene expression in normoxia or hypoxia. Macrophage M1 and M2-polarization was unchanged likewise. Compared to macrophages from wild type littermates $\mathrm{PHD}^{-/}$exhibited a significant reduction in TUNEL positive cells after serum withdrawal. Under the same conditions the $\mathrm{PHD}^{-/}$macrophages also showed less Annexin $\mathrm{V}$ staining which detects the membrane disruption indicating a reduced early apoptosis. Application of apoptotic inducers such as S-nitroso-N-acetyl penicillamine (SNAP) or staurosporine also showed $\mathrm{PHD}^{-/}$cells to be less apoptotic. Additionally, calcein uptake results indicate that $\mathrm{PHD}^{-/-}$ macrophages are more viable. When the supernatant (medium) from the cultured macrophages was exchanged between the genotypes after $24 \mathrm{hrs}$ of culture, then $\mathrm{PHD}^{-/}$macrophages showed more Annexin $V$ staining suggesting that at least in part a secreted factor is involved in the PHD3 induced apoptosis mechanism. In an unbiased transcriptome screen the expression of a secretory glycoprotein

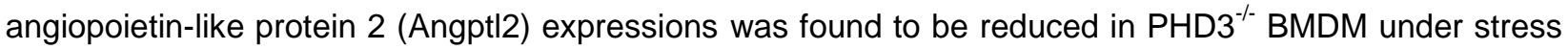
conditions. Addition of recombinant Angptl2 rescued the anti-apoptotic phenotype demonstrating that it is involved in the PHD3-mediated response towards apoptotic stimuli in macrophages. Additionally Angptl2 ${ }^{-/}$ BMDM showed decreased apoptosis compared to wild type which support the lower expression of Angptl2 in $\mathrm{PHD}^{-/}$BMDM followed by decreased apoptosis. My data suggests that the anti-apoptotic effects in the $\mathrm{PHD}^{-/-}$BMDMs are at least partially mediated by an altered production and response to Angptl2. 


\section{Introduction}

\subsection{Hypoxia}

Molecular oxygen $\left(\mathrm{O}_{2}\right)$ is essential for life; it plays an important role in human physiology. Subsequently, oxygen is indispensable for the molecular metabolism and adequate oxygen supply is the prerequisite for the appropriate functionality of each cell, tissue and organ (Carreau et al., 2011). Oxygen is available at the molecular level to tissues and cells by diffusion. The oxygenation in different tissues varies between $30-50 \mathrm{mmHg}$ which is comparable to $4-7 \%$ of the atmospheric pressure at sea level (Almendros et al., 2010; Qiao et al., 2007). Insufficient oxygen availability to tissues and cells is termed as hypoxia which can be caused by both physiological and pathophysiological reasons. A physiological condition that may lead to an increase of oxygen consumption and thus leads to hypoxia even at sea level, is for example heavy exercise (Garvey et al., 2012). In contrast to this, a pathophysiological condition, e.g. differentiation of stem cells inside the stromal niche during infection leads to inadequate supply of oxygen causing hypoxia which needs cellular adaptation to overcome the hypoxic effects (Carreau et al., 2011; Dunwoodie, 2009; Lee et al., 2001). Also a ventilation/perfusion mismatch resulting from progressive airflow limitation and emphysema can cause hypoxia leading to chronic obstructive pulmonary disease (Kent et al., 2011). Pathological hypoxia can be caused by local ischemia due to the loss of blood supply or in massive tumors because of impaired vascularization (Acker and Plate, 2003). Since oxygen is essential for the functioning of each and every tissue and organ the cell has regulatory mechanisms to adapt to the changes in oxygen availability. The key regulators of this response are the hypoxia-inducible transcription factors (HIFs) which activate oxygen-dependent gene expression (Fong, 2009).

\subsection{Hypoxia-inducible factors}

Hypoxia-inducible factors (HIFs) are transcription factors which accumulate under low oxygen concentrations and regulate the expression of hypoxia-inducible genes. HIFs are the principal mediators of homeostasis of cells and tissues experiencing hypoxia (Semenza, 2004). They regulate more than thousand target genes including those promoting angiogenesis, cell differentiation, anaerobic metabolism, 
and apoptosis (Semenza, 2012). HIFs are heterodimeric transcription factors consisting of an $\alpha$-subunit and a HIF-1 $\beta$-subunit, which is also known as aryl hydrocarbon receptor nuclear translocator (ARNT).

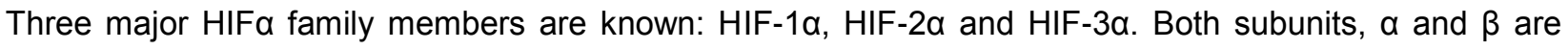
composed of basic helix-loop-helix proteins $(\mathrm{bHLH})$ of the Per-Arnt-Sim (PAS) family. HIF-1 $\beta$ forms a complex together with HIF-1 $\alpha$, HIF-2 $\alpha$ and HIF-3 $\alpha$ (Wang et al., 1995; Makino et al., 2002), these dimers bind to a DNA motif in the hypoxia response elements (HREs) that leads to the transcriptional activation (Wang et al., 1995; Wenger, 2002). HIF-1 $\beta$ mRNA and protein levels are unaltered with changes in oxygen availability. In contrast, in the presence of oxygen the HIFa subunits undergo the process of hydroxylation, polyubiquitination and proteasomal degradation, resulting in a half life of HIFa of about 5 min (Salceda and Caro, 1997). Low oxygen concentration leads to an insufficient hydroxylation and thereby to a HIFa subunit stabilization (Huang et al., 1998; Salceda and Caro, 1997; Roy et al., 2004). HIF-1 drives the initial response to hypoxia whereas HIF-2 plays an important role in chronic hypoxic exposure (Koh et al., 2011). HIF-3 acts as a negative regulator of HIF-1 and HIF-2 (Makino et al., 2002; Yamashita et al., 2008).

\subsubsection{HIF-1a}

The human HIF-1 $1 \alpha$ protein is constitutively and ubiquitously expressed and has a molecular weight of around $120 \mathrm{kDa}$ (Wang and Semenza, 1993). It is a member of the basic helix-loop-helix (bHLH) PAS protein family. HIF-1 $\alpha$ contains two transactivation domains; the N-terminal (N-TAD) and the C-terminal (C-TAD) and also contains an oxygen-dependent degradation domain (ODD) that regulates oxygen dependent stability (Pugh et al., 1997). The C-TAD interacts with co-activators like CBP/p300 to activate transcription. When N803 present in the C-TAD is hydroxylated it blocks the recruitment of transcriptional coactivator CBP/p300 (Ruas et al., 2002; Lando et al., 2002). The ODD domain contains two conserved proline residues, P402 and P564 that are hydroxylated by prolyl-4-hydroxylase domain enzymes (PHDs) and one lysine residue, K532 which is acetylated by acetyltransferase named arrest-defective-1 in an oxygen-dependent manner (Ke and Costa, 2006; Koh et al., 2011) (Fig. 1). The stability and activity of HIF-1 $\alpha$ are regulated by post-translational modifications such as hydroxylation, acetylation and ubiquitination (Kallio et al., 1999; Wang et al., 1995). Under normoxia, hydroxylation of two proline 
residues (P402 and P564), one asparagine residue (N803) and acetylation of a lysine residue (K532) triggers HIF-1a for poly-ubiquitination leading to degradation by the proteasome pathway (Ke and Costa, 2006; Koh et al., 2011; Mahon et al., 2001). HIF-1a is stabilized and active during short periods (2 - 24 hrs) of intense hypoxia or anoxia, subsequently negative feedback regulators lead to a decrease in the protein level.

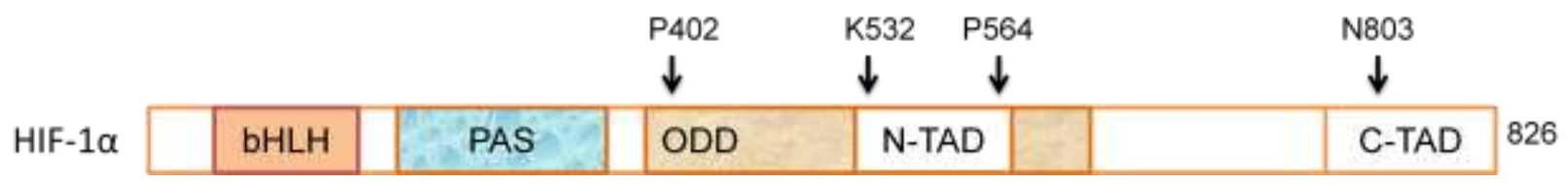

Figure 1: Domain structure of human HIF-1a

The protein contains two transactivation domains (C-TAD and N-TAD). HIF-1 $\alpha$ contains an ODD that mediates oxygen-regulated stability through the hydroxylation of two proline (P402 and P562) residues, an asparagines residue (N803) and the acetylation of a lysine (K 532).

\subsubsection{HIF-2 $\alpha$}

HIF-2 $\alpha$ has $48 \%$ of amino acid sequence and structure similarity to HIF-1 $\alpha$, but they have different target genes and mechanism of regulation. It is predominantly expressed in lung, epithelium and carotid body (Ema et al., 1997). HIF-2 $\alpha$ also contains transactivation domains at N-terminal (N-TAD) and C-terminal (CTAD) in the C-terminal half (Koh and Powis, 2012). The open reading frame of HIF-2 $\alpha$ encodes 870 aa with a molecular weight of the protein of $118 \mathrm{kDa}$ (Fig. 2). HIF-2 $\alpha$ is hydroxylated at much lower efficiency than HIF-1a (Koivunen et al., 2004) and therefore senses the chronic hypoxia exposure (Koh et al., 2011). In human HIF-2a is hydroxylated at the two conserved proline residues P405 and P531 (Koh et al., 2011) and the asparagine residue N 851 in the C-TAD domain is hydroxylated (Mahon et al., 2001)(Fig. 2).

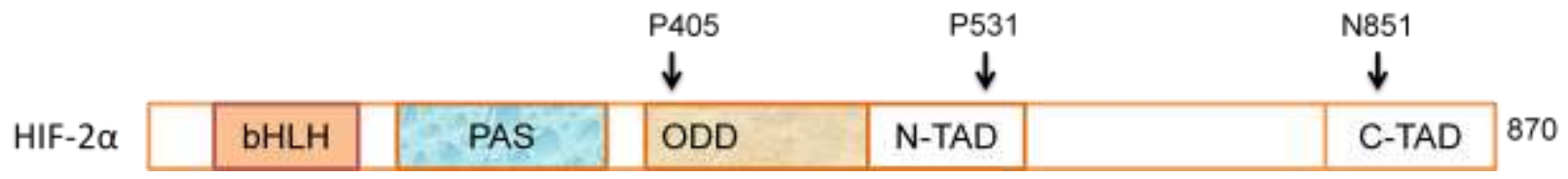

Figure 2: Domain structure of human HIF-2 $\alpha$

The protein contains two transactivation domains (C-TAD and N-TAD) and an oxygen-dependent degradation domain (ODD) containing conserved proline residue sites (P405 and P531) and asparagines site (N803). 


\subsubsection{HIF-3 $\alpha$}

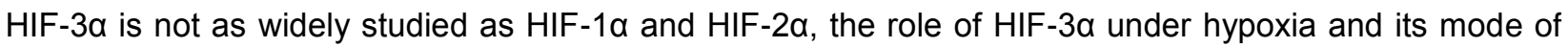
action is far more unclear. The HIF-3a open reading frame encodes 626 aa resulting in a protein with a molecular weight of $73 \mathrm{kDa}$ which is predominately expressed in adult thymus, lung, brain, heart, and kidney. It is the shortest HIFa-isoform composed of the bHLH and PAS domains but lacking the carboxyterminal domain (Gu et al., 1998), having only one TAD motif. It has a unique leucine zipper domain (LZIP) (Gu et al., 1998) (Fig. 3). Multiple splice variants of HIF-3a exist. The most studied variant is the inhibitory PAS domain protein (IPAS) (Makino et al., 2002). Under normoxia HIF-3a is degraded by hydroxylation in an oxygen dependent manner (Zhang et al., 2014) but in hypoxia it can inhibit the action of HIF- $1 \alpha$ and HIF-2 $\alpha$ by acting as a competitor against HIF-1 $\alpha$ or HIF-2 $\alpha$ by binding to Arnt or forming a dimer with HIF-1a itself (Makino et al., 2002; Yamashita et al., 2008; Hara et al., 2001).

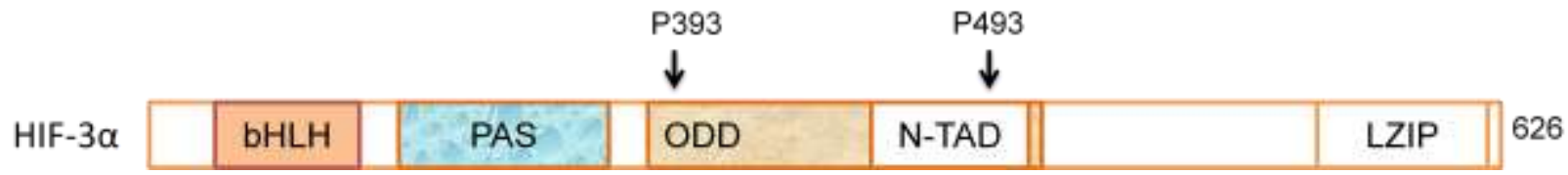

Figure 3: Domain structure of human HIF-3a

HIF-3 $\alpha$ contains besides the basic helix loop helix (bHLH) and Per-Arnt-Sim (PAS) domains only one transactivation domain (N$T A D$ ), an oxygen dependent domain (ODD) and a leucine zipper domain (LZIP).

\subsubsection{HIF-1 $\beta$}

HIF-1 $\beta$, also known as aryl hydrocarbon receptor nuclear translocator (Arnt), belongs to the bHLH protein family containing a PAS domain but it lacks the amino terminal N-TAD domain (Fig.4). HIF-1 $\beta$ consists of 789 aa with a molecular weight of $86 \mathrm{kDa}$ and is constitutively expressed irrespectively of oxygen availability and is stable under normoxic conditions. HIF-1 $\beta$ forms heterodimers with many bHLH-PAS

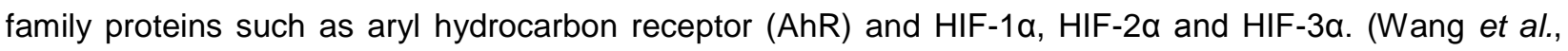
2006; Kallio et al., 1997). 


\section{\begin{tabular}{|l|l|l|l|l|}
\hline HIF-1 $\beta$ & bHLH & PAS & C-TAD 789 \\
\hline
\end{tabular}}

Figure 4: Domain structure of human HIF-1 $\beta$

HIF-1 $\beta$ contains besides the basic helix loop helix (bHLH) and Per-Arnt-Sim (PAS) domains one C-terminal transactivation domain (C-TAD).

\subsection{Regulation of HIFa}

The protein stability of HIFa is regulated by the prolyl-4-hydroxylase domain enzymes (PHDs) by hydroxylation at specific proline residues, followed by ubiquitination and proteasomal degradation (Jaakkola et al., 2001). Additionally, HIF-1 $\alpha$ and HIF-2 $\alpha$ are also regulated by asparaginyl hydroxylation leading to transcriptional inactivation by factor inhibiting HIF (FIH) (Lando et al., 2002). Both hydroxylase domain enzymes, PHDs and $\mathrm{FIH}$, require oxygen, 2-oxoglutarate, ascorbate and iron $\left(\mathrm{Fe}^{2+}\right)$ as co-factors (Jaakkola et al., 2001; Lando et al., 2002) (Fig. 5).

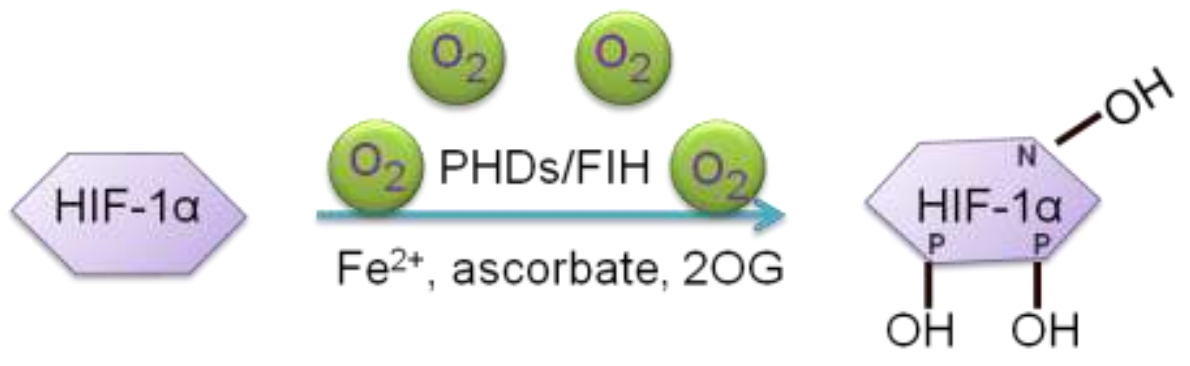

Figure 5: Hydroxylation of HIF-1a

Under the consumption of oxygen, hypoxia-inducible factor (HIF)-1a is hydroxylated at specific prolyl residues/asparagine residues by prolyl hydroxylase domain enzymes (PHDs)/factor inhibiting HIF $(\mathrm{FIH})$ in the presence of $\mathrm{Fe}^{2+}$ 2-oxoglutarate (2-OG) and ascorbate.

HIFa is hydroxylated by PHDs at two specific proline residues situated in the ODD domain which promotes interaction/binding of HIFa with the von Hippel-Lindau protein ( $\mathrm{pVHL}$ ) to the ODD domain of HIF. Binding of $\mathrm{pVHL}$ to the ODD forms a substrate recognition module of an E3 ubiquitin ligase complex 
which facilitates the polyubiqutination of HIFa thereby marking it for degradation by the $26 \mathrm{~S}$ proteasome (Kallio et al., 1999; Ohh et al., 2000). Under hypoxic conditions, because of the unavailability of oxygen as co-factor, the PHDs are inhibited from hydroxylating HIFa, which in turn inhibits the binding of pVHL hence leading to the stabilization of HIFa. Accumulated HIFa is then translocated into the nucleus where it heterodimerizes with HIF-1 $\beta$. The complex is able to activate the expression of hypoxia target genes by binding to cis-acting HRE located in the enhancer or promoter regions (Epstein et al., 2001; Jaakkola et al., 2001; Pugh and Ratcliffe, 2003). Hence, stabilization of HIFa affects various pathways in the cell for example angiogenesis, cell proliferation, metabolism, and apoptosis (Fig. 6). A high number of genes related to angiogenesis are upregulated under hypoxia. Vascular endothelial cell growth factor (VEGF) is one among them which recruits endothelial cells to the site of hypoxia and induces proliferation. The induction of VEGF in hypoxia is a sign of pro-angiogenesis and vessel formation (Josko et al., 2000). Also genes such as matrix metalloproteinases (MMPs) involved in matrix metabolism and vessel maturation are induced in hypoxia. Cells adapt to hypoxia by switching the metabolism from oxygen-dependent tricarboxylic acid cycle (TCA) cycle to oxygen independent glycolysis. To meet the required ATP synthesis the cells increase glucose uptake. Therefore, under hypoxia cells induce the expression of glycolytic enzymes such as pyruvate kinase M (PKM), Phosphofructokinase (Pfk), Hexokinase, and glucose transporters such as Glut 1 and Glut 3, which are indeed HIF target genes (Wenger, 2002; Mora et al., 2005; Chen et al., 2003). HIF also induces the expression of growth factors such as adrenomedullin, insulin like growth factor 2 and transforming growth factor- $\alpha$. Hifa stabilization also leads to the induction of apoptosis related genes such as BNip3, Bcl-2 and caspase-3 (Flamant et al., 2010; Webster et al., 2005; Regula, 2002). 


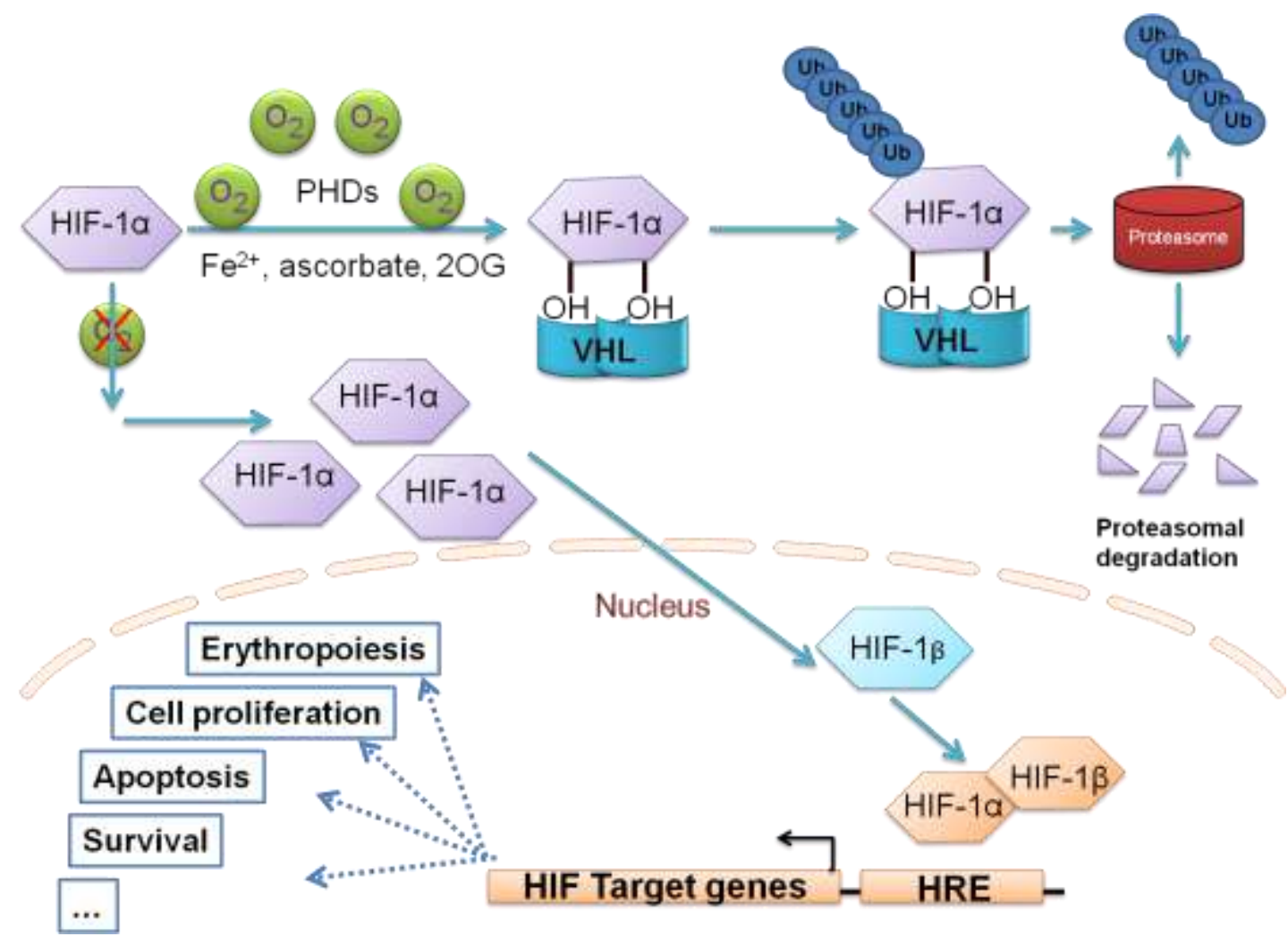

Figure 6: HIF-1a regulation by PHDs

In normoxia, hypoxia inducible factor (HIF)-1a is hydroxylated by prolyl hydroxylase domain enzymes (PHDs) in the presence of $\mathrm{O}_{2}$, $\mathrm{Fe}^{2+}, 2$-oxoglutarate (2-OG) and ascorbate. Hydroxylated HIF-1 $\alpha$ is recognised by the von Hippel-Lindau (pVHL) protein, which marks HIF-1 $\alpha$ with polyubiquitin, this leads to the recognition for proteasomal degradation. Under hypoxia, proline hydroxylation is inhibited, $\mathrm{VHL}$ is no longer able to bind and target HIF-1 $\alpha$ for proteasomal degradation, which leads to HIF-1 $\alpha$ accumulation and translocation to the nucleus. HIF-1 $\alpha$ dimerises with HIF-1 $\beta$, binds to hypoxia-response elements (HREs) within the promoters or enhancers of target genes and induces transcriptional activity. A range of cell functions are regulated by the target genes, such as cell proliferation, apoptosis, survival and erythropoiesis.

The second major mechanism controlling HIFa regulation is done by another oxygen regulated enzyme, FIH. FIH hydroxylates HIF at asparagines within the C-TAD domain. This hydroxylation inhibits the interaction with the transcription co-activators p300/CREB- and hence inhibits transcriptional activation of all target genes. Like PHDs, FIH also requires oxygen, 2-oxoglutarate, ascorbate and iron $\left(\mathrm{Fe}^{2+}\right)$ as cofactors (Lando et al., 2002; Mahon et al., 2001). 


\subsection{Prolyl-4-hydroxylase Domain Enzyme (PHD)}

PHDs are enzymes that use di-oxygen to hydroxylate their substrates and simultaneously convert 2oxoglutarate (2-OG) into succinate and release $\mathrm{CO}_{2}$ as byproduct (McDonough et al., 2006; Elkins et al., 2003). During hydroxylation, PHDs use the oxygen molecule, dissolve the covalent bond and split it into two, one oxygen atom hydroxylates the proline residue and the other reacts with 2-OG to generate succinate and $\mathrm{CO}_{2}$ (Bruick and McKnight, 2001; Masson and Ratcliffe, 2003). All the co-factors are essential for the hydroxylation activity of PHDs. For example, inhibition of the PHDs by 2-OG analogs can increase the half life of HIFa (Jaakkola et al., 2001). $\mathrm{Fe}^{2+}$ at the active site of the PHDs is bound to two histidine residues and one aspartic acid forming a 2-histidine-1-carboxylate coordination motif. Ascorbate helps to maintain iron in the ferrous $\left(\mathrm{Fe}^{2+}\right)$ state which is important to achieve the full enzyme activity (Epstein et al., 2001; Bruick and McKnight, 2001). The apparent $K_{M}$ value for all the PHD enzymes is in between $230-250 \mu \mathrm{M}$ which exceeds even the concentration of oxygen in air at sea level making these enzymes suitable oxygen sensors (Hirsila et al., 2003). In Drosophila melanogaster and Caenorhabditis elegans similar to PHDs a single family member is present which is known as Fatiga and egg laying defective nine (EGLN) respectively (Epstein et al., 2001; Centanin et al., 2005). In mammals, there are four members that belong to the PHD protein family, PHD1 also known as EGLN2, PHD2 also known as EGLN1, PHD3 also known as EGLN3 and the recently discovered P4HTM (prolyl 4-hydroxylase, transmembrane). In addition to being oxygen sensors, PHDs are also known to be involved in the hydroxylation of non-HIF substrates and also in hydroxylase independent functions (for examples please see table 1.2) (Cummins et al., 2006; Takeda and Fong, 2007; Ozer et al., 2005).

All PHDs can hydroxylate HIFa in-vitro; however there are differences in the hydroxylation potential, PHD2 has the highest potential followed by PHD3, and PHD1. PHD2 is the most important enzyme for hydroxylating HIFa in normoxia. (Huang et al., 2002). Under hypoxia, mRNA and protein expression of PHD2 is mildly induced, expression of PHD3 is strongly induced under hypoxia whereas expression of PHD1 remains unaffected (Epstein et al., 2001; Metzen et al., 2003). PHD2 is mostly localized in the cytoplasm, PHD1 is localized in the nucleus and PHD3 is localized both in cytoplasm and nucleus. PHD2 shuttles between the cytoplasm and the nucleus for degradation of HIFa in both compartments (Metzen et 
al., 2003). All enzymes are expressed widely in many tissues but they exhibit tissue specific overexpression. PHD1 is abundant in the testis, PHD2 in skeletal muscles and adipose tissue, PHD3 in the heart and placenta (Lieb et al., 2002).

The structure of PHDs consists of two domains: the variable N-terminal domain $(\approx 21-58$ aa) has homology to MYND zinc finger domains and the conserved catalytic C-terminal domain $(\approx 181-426$ aa) has homology to other 2-OG dioxygenases. The catalytic core domain of PHDs consists of eight $\beta$ strands/double stranded $\beta$-helices supported by three conserved $\alpha$-helices and other $\beta$-strands and loops that pack along the core (McDonough et al., 2006)(Fig. 7).

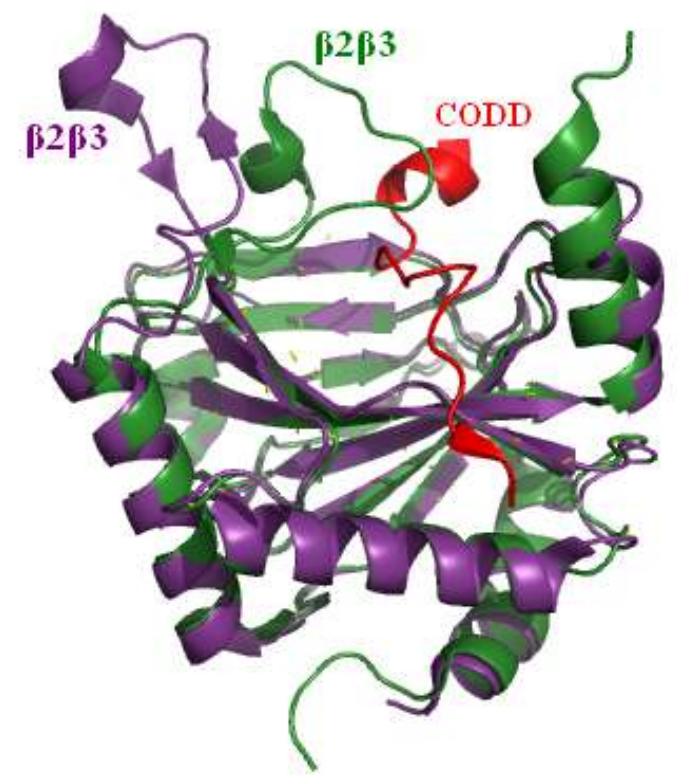

Adapted from (McDonough et al., 2006)

Figure 7: Crystal structure of PHD2

PHD2 consists of a C-terminal domain and a N-terminal domain formed by eight $\beta$-strands in a "jelly-role"or double stranded $\beta$ helix supported by three conserved $\alpha$-helices and other $\beta$-strands and loops that pack along the core. This core contains the three $\mathrm{Fe}^{2+}$ binding ligands. 


\subsubsection{PHD1}

PHD1 also named as EGLN2, is constitutively expressed but predominantly expressed in testis and localized in the nucleus. Full length human PHD1 consists of 407 aa and has a molecular weight of around $43 \mathrm{kDa}$. Resulting from two alternative translational initiations, PHD1 has two isoforms with molecular weights of 40 and 43 kDa. (Epstein et al., 2001; Lieb et al., 2002). PHD1 has been shown to be involved in the mitochondrial energy metabolism (Aragones et al., 2008). Loss of PHD1 decreases oxidative stress in liver cell metabolism resulting in increased hypoxic survival (Schneider et al., 2010) and increases the intestinal barrier function and thus is protective against colitis (Tambuwala et al., 2010).

\subsubsection{PHD2}

PHD2 also known as EGLN1, consists of 426 aa and has a molecular weight of $46 \mathrm{kDa}$ and is highly expressed in skeletal muscles and adipose tissue. PHD2 is the most important enzyme to hydroxylate HIFa in normoxia (Huang et al., 2002). Therefore human hereditary mutations of PHD2 results in a decreased enzyme activity and are associated with familial erythrocytosis, one such mutation is P317R (Percy et al., 2006). The complete knockout of PHD2 is lethal (Takeda et al., 2006). PHD2 has a higher specificity towards HIF-1 $\alpha$ compared to HIF-2 $\alpha$ and is transcriptionally regulated by HIF. Therefore it is mildly induced under hypoxia. PHD2 is known to play a major physiological role during placental and cardiac development (Takeda et al., 2006). In mice haplodeficiency of PHD2 can normalize the vasculature of expanding tumors, leading to improved tumor oxygenation and delay in metastasis (Mazzone et al., 2009).

\subsubsection{PHD3}

Human PHD3 also known as EGLN3 is a 239 aa long protein with a molecular weight of $27 \mathrm{kDa}$ and is mostly expressed in the heart and placenta. PHD3 protein is transcriptionally upregulated by HIF (Pescador et al., 2005) and is strongly hypoxia inducible (Appelhoff et al., 2004). The specific role of PHD3 upregulation under hypoxia is not clear. However, studies suggest that the hypoxic induction of PHD3 may play a predominant role in regulating HIFa via a feedback loop (Appelhoff et al., 2004). It has 
already been demonstrated that acute induction of hypoxia leads to a transient rise in HIF-1a protein levels, following a brief time period these levels subsequently return back to baseline despite continued hypoxia. This might have resulted from the hypoxia-induced PHD3 expression, which enables cells to effectively increase HIF-1 $\alpha$ hydroxylation even under hypoxia.

PHD3 has been reported to be involved in the development of the sympatho-adrenal system (Bishop et al., 2008) and induces apoptosis in cultured rat sympathetic neurons by withdrawal of nerve growth factor (Lipscomb et al., 1999). Also it has been shown to induce apoptotic cell death in neurons and pheochromocytoma cell line (PC12) cells (Lipscomb et al., 2001; Lee et al., 2005). In relation to myeloid cells, PHD3 has been shown to regulate the life span of neutrophils under hypoxia (Walmsley et al., 2011). In macrophages, loss of PHD3 enhances the innate immune response by accumulating proinflammatory macrophage function (Kiss et al., 2012). Other than myeloid cells, PHD3 negatively regulates the NFKB pathway (Fu and Taubman, 2013; Xue et al., 2010). Upregulation of PHD3 is associated with p53 induced growth arrest and apoptosis in Rat sarcoma (RAS)-transformed embryo fibroblasts (Madden et al., 1996). PHD3 stimulates pyruvate kinase M2 co-activation of HIF-1 (Luo et al., 2011) and it regulates Bcl-2 mediated apoptosis in H9c2 cells (Liu et al., 2010). PHD3 targets and interacting proteins are listed below in the table 1.1.

Table 1.1 adapted from (Place and Domann, 2013)

\begin{tabular}{|llll|}
\hline Targets & Function & Interaction & Reference \\
\cline { 2 - 3 } & Degradation & Hydroxylation & (Elkins et al., 2003; \\
& & & Appelhoff et al., \\
& & & $2004)$ \\
\hline ATF-4 & Regulator of transcription & Binding & (Wottawa et al., \\
& factor & & $2010 ;$ Koditz et al., \\
& HIF-1 activation & Hydroxylation & 2007) \\
\hline PKM2 & Degradation of PHD3 & Binding & (Luo, Hu et al. 2011) \\
\hline Siah2 & & & (Nakayama et al., \\
& & & 2009) \\
\hline
\end{tabular}




\begin{tabular}{|lllr|}
\hline Bcl-2 & $\begin{array}{l}\text { Reduce formation of Bax- } \\
\text { Bcl-2 complex }\end{array}$ & Binding & \\
\hline hCLK2 & DNA damage & Hydroxylation 2010$)$ \\
\hline IKK $\boldsymbol{\beta}$ & $\begin{array}{l}\text { Negative regulator of } \\
\text { NFKB }\end{array}$ & Binding & (Xie et al., 2012) \\
\hline $\begin{array}{l}\text { Kinesin like } \\
\text { protein1B } \boldsymbol{B}\end{array}$ & Induction of apoptosis & Hydroxylation & (Xue al., 2010) \\
\hline
\end{tabular}

\subsubsection{Known role of PHD3 in pro-survival effect}

PHD3 has been shown in many studies to have a pro-survival role by affecting apoptotic pathways under hypoxic conditions in several cell types. For example, PHD3 has also been known to play a role in cell viability under hypoxic conditions in tumor samples where its upregulation correlates with increased aggressiveness in cancers (Chen et al., 2011b), also in head and neck carcinoma cells PHD3 appears to promote cell cycle progression from G1-S phase (Hogel et al., 2011). PHD3 has been shown to increase the life span of neutrophils under hypoxia (Walmsley et al., 2011). One mechanism, known for this increased survival is the effect of PHD3 on cell metabolism. Both PHD3 and PKM2 have been shown to complex with nuclear HIF-1a, inducing transcription of genes involved in glycolysis (Luo et al., 2011). This leads to a higher production of ATP through the glycolytic pathway during hypoxia. A similar study showed an interaction between PKM2 and PHD3 in the cytosol, where it regulates flux of carbon through glycolysis (Chen et al., 2011a). Thus, under hypoxia PHD3 may promote cell survival by modulating metabolic genes.

\subsubsection{Known role of PHD3 in pro-apoptotic effect}

In spite of several studies pointing towards the role of PHD3 in cell survival, evidence for the role of PHD3 in inducing apoptosis is pre-dominant in the literature. It has been shown in neurons during sympathoadrenal development that loss of PHD3 resulted in a decrease of apoptotic cells (Bishop et al., 2008). Withdrawal of nerve growth factor from cultures of neuronal-derived cell lines leads to upregulation 
of PHD3 (Lee et al., 2005; Lipscomb et al., 1999). Another similar study shows that, nerve growth factor withdrawal from a rat pheochromocytoma cell line resulted in c-jun mediated PHD3 upregulation inducing cell death (Straub et al., 2003). Kinesin KIF1B $\beta$ has been shown to act downstream of PHD3 to mediate pro-apoptotic effects (Schlisio et al., 2008). Apart from neurons, also in muscle cells PHD3 has been shown to interact with $\mathrm{Bcl}-2$, inhibiting the formation of the Bax-Bcl-2 complex which finally results in cell apoptosis (Liu et al., 2010). Further, PHD3 hydroxylates human Biological Clock Protein (hCLK2) and promotes apoptosis through activation of the p53 mediated DNA damage response pathway (Xie et al., 2012). In a cervical cancer cell line it has been shown that PHD3 localizes into large punctuated cytoplasmic aggregates followed by apoptosis (Rantanen et al., 2008).

\subsection{PHDs targets other than HIFs}

PHDs can regulate other downstream targets than HIFs although it is not clear if it involves direct hydroxylation by the involved PHDs or not. For example PHD1 and PHD3 inhibit the IkB kinase (IKK) in the NFKB pathway (Xue et al., 2010). Another role of PHD3 is the hydroxylation of pyruvate kinase isoform PKM2 which enhances the PKM2 binding to HIF-1a (Luo et al., 2011). PHD2 may directly interact with Phosphodiesterase 4D to function as a regulator of the intracellular cAMP levels in cardiomyocytes (Huo et al., 2012). A recent study showed that PHD3 regulates the ion channel TRPA1 by hydroxylation (Takahashi et al., 2011). Table1.1 below summarizes all the targets and binding partners of the different PHDs known so far.

Table1.2 adapted from (Wong et al., 2013)

\begin{tabular}{|c|c|c|c|c|}
\hline Target & Abbreviation & PHD Isoform & Interaction & Reference \\
\hline $\begin{array}{l}\text { Inhibitor of kappaB } \\
\text { kinase } \beta\end{array}$ & $\mathrm{IKK} \beta$ & PHD1/2/3 & Hydroxylation & $\begin{array}{l}\text { (Fu and Taubman, } \\
\text { 2010; Cummins et } \\
\text { al., 2006) }\end{array}$ \\
\hline $\begin{array}{l}\text { Pyruvate kinase muscle } \\
\text { factor2 }\end{array}$ & PKM2 & PHD2 & Binding & (Luo et al., 2011) \\
\hline LIN-10 & LIN-10 & Egl-9E & Binding/Hydroxylation & (Park et al., 2012) \\
\hline
\end{tabular}




\begin{tabular}{|c|c|c|c|c|}
\hline $\begin{array}{l}\text { Transient receptor } \\
\text { potential cation channel, } \\
\text { member } \mathbf{A} 1\end{array}$ & TRPA1 & PHD1/3 & Hydroxylation & $\begin{array}{l}\text { (Takahashi et al., } \\
\text { 2011) }\end{array}$ \\
\hline FK506 binding protein 38 & FKBP38 & PHD2 & Binding & (Barth et al., 2009) \\
\hline $\begin{array}{l}\text { Seven in absentia } \\
\text { homolog } 2\end{array}$ & Siah2 & PHD3 & Binding & $\begin{array}{l}\text { (Nakayama et al., } \\
\text { 2007) }\end{array}$ \\
\hline $\begin{array}{l}\text { Activation transcription } \\
\text { factor } 4\end{array}$ & ATF4 & PHD1/3 & Binding & $\begin{array}{l}\text { (Koditz et al., } \\
\text { 2007; Hiwatashi et } \\
\text { al., 2011) }\end{array}$ \\
\hline $\begin{array}{l}\text { Human precursor RNA } \\
\text { processing } 19\end{array}$ & hPRP19 & PHD3 & Binding & (Sato et al., 2010) \\
\hline Paired box gene 2 & Pax2 & PHD3 & Hydroxylation & (Yan et al., 2011) \\
\hline Sprouty homolog 2 & Spry2 & PHD1/2/3 & Hydroxylation & $\begin{array}{l}\text { (Anderson et al., } \\
\text { 2011)Anderson, } \\
\text { Nordquist et al., } \\
\text { 2011) }\end{array}$ \\
\hline TCP-1 ring complex & TRiC & PHD3 & Binding & $\begin{array}{l}\text { (Masson et al., } \\
2004)\end{array}$ \\
\hline $\begin{array}{l}\text { Mitogen-activated } \\
\text { protein kinase organizer } \\
1\end{array}$ & Morg1 & PHD3 & Binding & $\begin{array}{l}\text { (Hopfer et al., } \\
2006)\end{array}$ \\
\hline $\begin{array}{l}\text { Inhibitor of growth } \\
\text { protein } 4\end{array}$ & ING4 & PHD2 & Binding & (Ozer et al., 2005) \\
\hline $\begin{array}{l}\text { Iron-only hydrogenase- } \\
\text { like protein1 }\end{array}$ & IOP1 & PHD2 & Binding & $\begin{array}{l}\text { (Huang et al., } \\
2007 \text { ) }\end{array}$ \\
\hline $\begin{array}{l}\text { Cerebellar degeneration } \\
\text { related protein } 2\end{array}$ & Cdr2 & PHD1 & Binding & $\begin{array}{l}\text { (Anderson et al., } \\
2011 ; \\
\text { Balamurugan et } \\
\text { al., 2009) }\end{array}$ \\
\hline Myogenin & Myogenin & PHD3 & Hydroxylation & (Fu et al., 2007) \\
\hline
\end{tabular}




\begin{tabular}{|lllll|}
\hline Kinesin-like protein1B $\boldsymbol{\beta}$ & KIF1B $\beta$ & PHD3 & Hydroxylation & (Schlisio et al., \\
& & & & 2008) \\
\hline $\begin{array}{l}\text { Large subunit of RNA } \\
\text { polymerase II }\end{array}$ & Rbp1 & PHD1/2 & Hydroxylation & (Mikhaylova et al., \\
& & & & $2008)$ \\
\hline
\end{tabular}

\subsection{Hypoxia and myeloid cells}

Myeloid cells are comprised of cells having common descendants from progenitors derived from hematopoietic stem cells in the bone marrow. Granulocytes and monocytes together are called myeloid cells. These are short living immune cells that respond and move to any change in tissue integrity or microbial invasion. They move to the affected tissue and phagocytose the microorganisms and damaged tissue debris or release antimicrobial molecules and pro-inflammatory factors. The role of macrophages and neutrophils in the regulation of microbial infection and inflammation is the central mechanism of innate immunity. In particular neutrophil apoptosis is important for the onset of granulocytic inflammation. HIF-1 is known to prolong the neutrophil viability by inhibiting apoptosis under hypoxia (Walmsley et al., 2005) and in von Hippel-Lindau disease having mutation in one VHL allele, neutrophils showed reduced apoptosis and induced phagocytosis of bacteria (Walmsley et al., 2008). In myeloid cells, HIF-1a knockout shows less efficient phagocytosis in eliminating bacteria during infection (Peyssonnaux et al., 2005). HIFdependent functions of myeloid cells in oxygen depleted areas are well known (Cramer et al., 2003).

\subsubsection{Hypoxia and macrophages}

Macrophages are highly elastic immune cells which are derived from bone marrow progenitors, which proliferate continuously and release monocytes into the blood stream. Monocytes circulate in the blood stream for 1-2 days before migrating into the tissues to differentiate into macrophages, which exhibit various tissue specific functions and protect the body from infection by bacteria, viruses and other pathogens. Therefore, macrophages are found in all kind of tissues of the body. Huge extravasation of monocytes into the tissue is a sign of early onset of inflammation. Wound healing and various diseases in which macrophages exhibit a range of functions such as hypoxic survival, phagocytosis, bacterial killing, 
antimicrobial activity, antigen presenting and tissue invasion (Fig. 1.8) (Ross and Rosen, 2002). Tissue hypoxia can be caused by various ways such as inflammation, wound healing or due to occlusion of the local blood supply. It has been shown in the literature that macrophages accumulate in large numbers in such hypoxic tissues and respond to the hypoxia by altered gene expression mediated by activation of both HIF-1 and HIF-2 target genes (Semenza, 2004; Burke et al., 2003; Talks et al., 2000). Numerous studies showed the changes in gene expression in macrophages in the hypoxic sites, for example altered VEGF, Glut-1, IL-1, TNF- $\alpha$, IL-6, MMPs have been shown in the literature in macrophages under hypoxia (Lewis et al., 2000).

Wounds have areas of hypoxia due to lack of perfusion caused by vascular damage. Initially neutrophils infiltrate the wound, increase their number and stay at the hypoxic site for 1-2 days post wound formation. This is followed by monocyte recruitment which peaks at days 2 till 5 . Both macrophages and neutrophils phagocyte debris and secrete factors which attract additional immune cells to the site of the wound that facilitate neovascularization (Allen et al., 1997). In an animal model of myocardial infarction, hypoxic areas are detected, where significantly higher numbers of macrophage accumulation has been shown

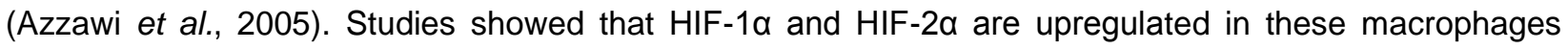
found in infarcted tissues (Jurgensen et al., 2004). 


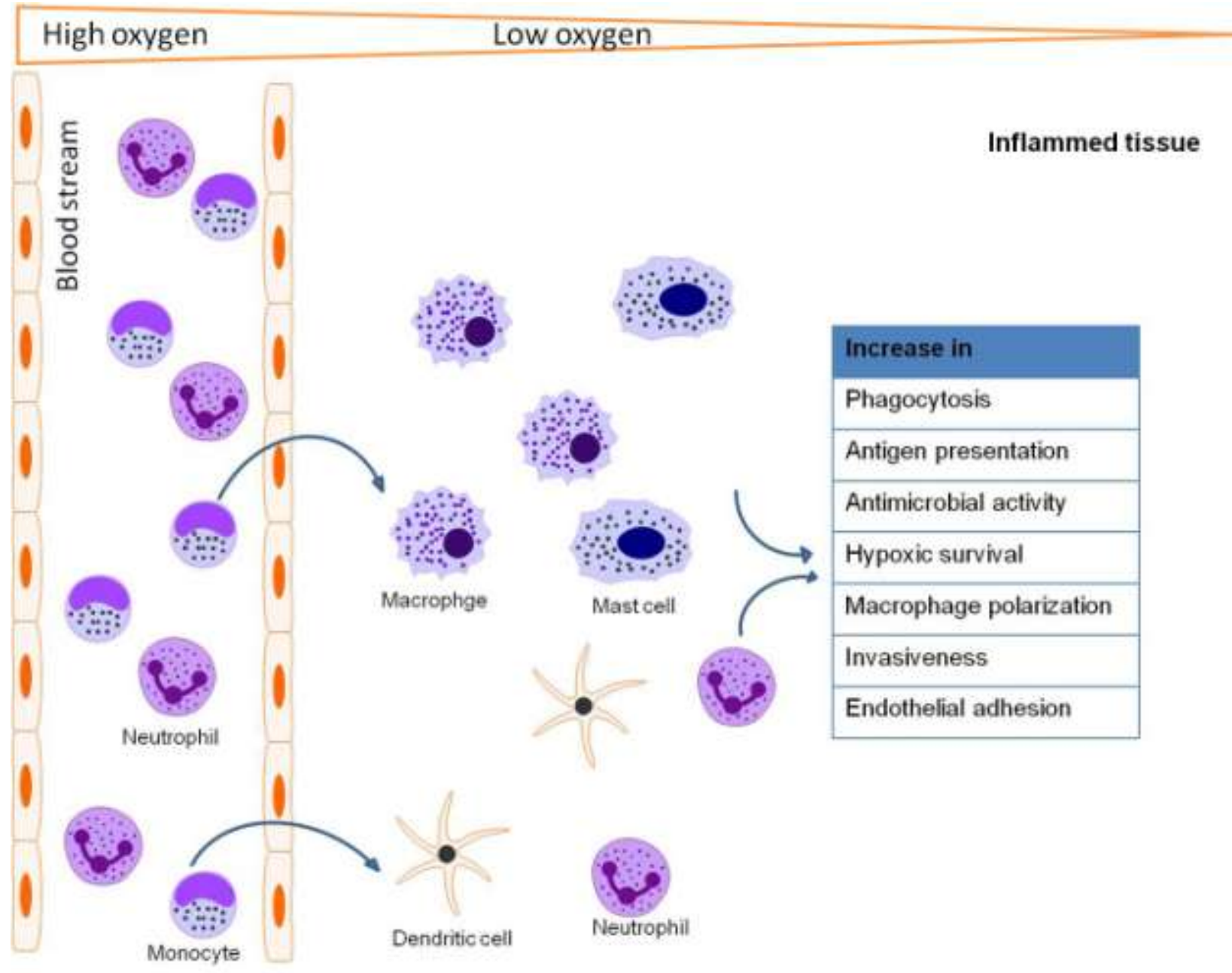

Figure adapted and modified from (Eltzschig and Carmeliet, 2011)

Figure 8: Myeloid cell response to hypoxia/ inflammation

The schematic explains the invasion of immune cells to the hypoxic or inflamed site. Inflamed hypoxic tissue mount a host defense response which amplifies the recruitment of innate immune cells such as neutrophils, mast cells or macrophages to the site of infection.

\subsection{Angiopoietin-like protein 2 (Angptl2)}

Angiopoietins belong to the family of proteins which regulate angiogenesis and hematopoietic stem cell differentiation (Yancopoulos et al., 2000; Suda et al., 2005) . It has been reported that tyrosine kinase with immunoglobulin-like and EGF-like domains 1 (Tie2) is the receptor for the members of the angiopoietin family (Davis et al., 1996; Suri et al., 1996). Recently, a protein family structurally similar to angiopoietins 
was identified and is designated as angiopoietin-like proteins (Angptls). Angptls contain an $\mathrm{N}$-terminal coiled-coil domain and a C-terminal fibrinogen-like domain (Hato et al., 2008). They do not bind to the receptor Tie2, suggesting that Angptls have a different signaling mechanism than that of angiopoietins (Hato et al., 2008). It has recently been reported that LILRB2 and PIRB are receptors for several Angptl family members (Zheng et al., 2012; Oike et al., 2004). The family of Angptls consists of seven members, Angpt11-7.

Angptl2 is constitutively expressed in several cell types including monocytes and macrophages and in tumor cells (Okada et al., 2010; Aoi et al., 2011; Tazume et al., 2012). It has been reported that Angptl2 plays a crucial role in mediating obesity, tumor metastasis, rheumatoid arthritis and in inducing atherosclerotic diseases through chronic inflammation (Tabata et al., 2009; Tazume et al., 2012; Endo et al., 2012; Aoi et al., 2011; Okada et al., 2010).

\subsection{Angptl2 and inflammation}

Literature reports several studies about the role of Angptl2 in both chronic and acute inflammation. For example, Angpt12 has been reported to mediate persistent low grade inflammation by activating NFKB signaling through $\alpha 5 \beta 1$ integrin receptor (Tabata et al., 2009). Another similar study suggests that Angptl2 derived from infiltrating macrophages accelerates abdominal aortic aneurysm progression by inducing chronic inflammation and degradation in the aneurismal vessel wall (Tazume et al., 2012). Studies also show correlation between chronic inflammation and Angptl2 expression level which induces tumor metastasis (Aoi et al., 2011). This study was done by inducing skin squamous cell carcinoma (SCC) in a mouse model and expression of Angptl2 in this mouse model correlates with the frequency of carcinogenesis which is found to be caused by the accumulation of ROS due to chronic inflammation. Higher ROS level can inhibit the DNA repair enzyme machinery leading to increased risk of carcinogenesis (Aoi et al., 2011). Also during acute inflammation, Angptl2 has been shown to be induced by endotoxin in the eye (Kanda et al., 2012). Angptl2 is also induced during fin regeneration in adult zebrafish, further supporting a role of Angptl2 in inflammation (Kubota et al., 2005; Boehler et al., 2011). 
Interestingly, reports also showed a stress related induction in the expression and secretion of Angpt|2. In adipocytes, ER stress increases Angptl2 expression and secretion (Tabata et al., 2009). Most interestingly, Angptl2 mRNA levels in tumor cells are significantly increased under hypoxia and starvation (Endo et al., 2012), suggesting a link between cellular stress and hypoxia signaling pathways. 


\subsection{Aim of the study}

The stability of the transcription factor HIFa is regulated by PHD enzymes in an oxygen dependent manner. Under normoxia PHD1-3 enzymes utilize molecular oxygen to hydroxylate HIFa and mark it for proteasomal degradation. Contrary, under hypoxic conditions HIFa is stabilized and can modulate hypoxia-dependent cell functions. Hypoxia is a common feature of infected and inflamed tissues, tumors, wounds, and atherosclerotic lesions. Myeloid cells are attracted to these hypoxic areas and a strong accumulation of macrophages can be observed. They are able to adapt rapidly to hypoxia by altered gene and protein expression profiles by activating hypoxia inducible factor signaling pathways and this influences the outcome of the diseases. The involvement of HIF in modulating inflammation has been well described in the literature. As macrophage function and hypoxia are important players in health and disease I aimed to investigate how macrophages are influenced by targeting HIF-signaling. PHDs are known to be expressed in myeloid cells and interfering with any of these PHD isoforms might alter the response of the immune system. As the PHD isoforms differ in enzyme activity, the isoform specific function of PHDs in myeloid cells needs to be investigated separately. A huge number of recent studies support the role of PHD3 in cell differentiation, survival, apoptosis, and metabolism. In myeloid cells loss of PHD3 is known to enhance the innate immune response (Kiss et al., 2012) and regulate the life span of neutrophils under hypoxia (Walmsley et al., 2011). However the specific role of PHD3 in macrophages is less explained so far. Therefore, the aim of this thesis was to investigate the role of PHD3 in macrophage specific function in a newly generated myeloid specific PHD3 knockout mouse line. To investigate the broad role following sub goals were set.

a) Isolation, differentiation and characterization of $\mathrm{PHD}^{-/-} \mathrm{BMDMs}$ - I first aimed to isolate and differentiate BMDM and do general characterization of these in-vitro 8 days differentiated macrophages. These characterizations include confirming the knockdown by protein expression and gene expression analysis, doing morphological analysis and examining the macrophage differentiation efficiency.

b) To examine the polarization of macrophages - Macrophages can differentiate into two subpopulations which carry out distinct and time overlapping functions. Therefore another sub aim 
was to investigate if the $\mathrm{PHD}^{-/-}$BMDM differentiate into a distinct subpopulation both with and without stimulations by gene expression analysis and cytokine protein expression analysis.

c) To identity the effect of $\mathrm{PHD}^{-/-}$on BMDM viability - For PHD3 a connection to apoptotic cell death mechanisms has been reported in various cell type. Therefore I was interested to investigate the effect of $\mathrm{PHD}^{-/}$in BMDMs using assays such as TUNEL assay, Annexin $\mathrm{V}$ assay, and calcein uptake assay.

d) Molecular studies of $\mathrm{PHD}^{-/}$BMDM - To further identify the molecular mechanisms of PHD3 on macrophage function I performed a transcriptome screen and analyzed the identified candidate Angptl2 in more detail. 


\section{Materials and methods}

\subsection{Materials}

\subsubsection{Chemicals}

Table 2.1: List of used chemicals and materials

\begin{tabular}{|c|c|}
\hline Name of the chemical & Provider \\
\hline $\begin{array}{l}\text { 3-(4,5-dimethylthiazol-2-yl)-2,5-diphenyl- } \\
\text { tetrazoliumbromid (MTT) }\end{array}$ & Enzo Life Sciences, Lörrach, Germany \\
\hline $\begin{array}{l}\text { 3-trimethylammoniopropyl } \\
\text { methanethiosulphonate bromide (TAPS- } \\
\text { sulphonate) }\end{array}$ & Wako Pure chemicals, Osaka, Japan \\
\hline Accutase & PAA Laboratories, Cölbe, Germany \\
\hline Bovine serum albumin & Applichem, Darmstadt, Germany \\
\hline Complete Mini EDTA-free Protease Inhibitor & Roche Applied Science, Mannheim, Germany \\
\hline Dimethyl sulfoxide (DMSO) & Carl Roth GmbH, Karlsruhe, Germany \\
\hline Dimethyloxaloylglycine (DMOG) & Frontier Scientific, Carnforth, UK \\
\hline EDTA & PAN ${ }^{\text {Im }}$ biotech $\mathrm{GmbH}$, Passau, Germany \\
\hline Fetal calf serum & PAN ${ }^{\prime m}$ biotech $\mathrm{GmbH}$, Passau, Germany \\
\hline GeneRuler $^{\mathrm{TM}}$ 1kb Plus DNA Ladder & Fermentas GmbH, St. Leon-Rot, Germany \\
\hline Glycine & Carl Roth GmbH, Karlsruhe, Germany \\
\hline HEPES & PAN ${ }^{\text {Im }}$ biotech $\mathrm{GmbH}$, Passau, Germany \\
\hline Horse serum & PAN 'm biotech $\mathrm{GmbH}$, Passau, Germany \\
\hline Interferon $\gamma($ IFN $\gamma)$ & Peprotech, Hamburg, Germany \\
\hline Interleukin (IL)-4 & Peprotech, Hamburg, Germany \\
\hline $\mathrm{KCl}$ & Carl Roth GmbH, Karlsruhe, Germany \\
\hline L-glutamine & PAN $^{\text {'m }}$ biotech $\mathrm{GmbH}$, Passau, Germany \\
\hline
\end{tabular}




\begin{tabular}{|c|c|}
\hline Lipopolysaccharide (LPS) & Enzo Life Sciences, Lörrach, Germany \\
\hline Methanol & Carl Roth GmbH, Karlsruhe, Germany \\
\hline $\mathrm{NaCl}$ & Carl Roth GmbH, Karlsruhe, Germany \\
\hline $\mathrm{NaOH}$ & Carl Roth GmbH, Karlsruhe, Germany \\
\hline PageRuler $^{\mathrm{TM}}$ Prestained Protein Ladder & Fermentas GmbH, St. Leon-Rot, Germany \\
\hline Penicillin/streptomycin for cell culture & PAN"' biotech GmbH, Passau, Germany \\
\hline Phalloidin & Invitrogen, Germany \\
\hline S-nitroso-N-acetylpenicillamine (SNAP) & Santa Cruz \\
\hline Sodium Citrate & Carl Roth GmbH, Karlsruhe, Germany \\
\hline Sodium dodecyl sulfate (SDS) & Carl Roth GmbH, Karlsruhe, Germany \\
\hline Sodium Pyruvate & PAN $^{\text {'m }}$ biotech $\mathrm{GmbH}$, Passau, Germany \\
\hline Staurosporine & Enzo Life Sciences, Lörrach, Germany \\
\hline Super signal ECL & Merck Millipore, Darmstadt, Germany \\
\hline $\begin{array}{l}\text { Tetramethylethylenediamine } \\
\text { (TEMED) }\end{array}$ & Carl Roth GmbH, Karlsruhe, Germany \\
\hline Triton $\mathrm{X}$ & Carl Roth $\mathrm{GmbH}$, Karlsruhe, Germany \\
\hline Triton $\mathrm{X}-100$ & Carl Roth $\mathrm{GmbH}$, Karlsruhe, Germany \\
\hline Trizol & Invitrogen, Darmstadt, Germany \\
\hline Trypan blue & Sigma, United Kingdom \\
\hline$\beta$-mercaptoethanol & Carl Roth $\mathrm{GmbH}$, Karlsruhe, Germany \\
\hline Annexin V & Biolegend,London, United Kingdom \\
\hline Propidium iodide & Biolegend,London, United Kingdom \\
\hline
\end{tabular}




\subsubsection{Buffers}

Table 2.2 List of buffers used

\begin{tabular}{|c|c|}
\hline Buffer & Composition \\
\hline Western blot transfer buffer & $\begin{array}{l}25 \mathrm{mM} \text { Tris } \\
192 \mathrm{mM} \text { glycine } \\
800 \mathrm{ml} \mathrm{H}_{2} \mathrm{O} \\
10 \% \mathrm{SDS} \\
200 \mathrm{ml} \text { methanol }\end{array}$ \\
\hline DEPC-treated water & $\begin{array}{l}2 \mathrm{ml} \text { diethylpyrocarbonate } \\
1 \mathrm{I} \mathrm{H}_{2} \mathrm{O}\end{array}$ \\
\hline $\begin{array}{l}\text { Enhanced luminol-based chemiluminescent } \\
\text { substrate (ECL) }\end{array}$ & $\begin{array}{l}100 \mathrm{mM} \text { Tris/ } \mathrm{HCl}, \mathrm{pH} 8.5 \\
90 \mathrm{mM} \text { coumaric acid } \\
250 \mathrm{mM} \text { luminol } \\
0.009 \% \mathrm{H}_{2} \mathrm{O}_{2}\end{array}$ \\
\hline Lysis Buffer & $\begin{array}{l}400 \mathrm{mM} \mathrm{NaCl} \\
10 \mathrm{mM} \text { Tris/HCl, pH } 8 \\
1 \mathrm{mM} \text { EDTA, pH } 8 \\
0.1 \% \text { TritonX100 } \\
\mathrm{H}_{2} \mathrm{O}\end{array}$ \\
\hline Phosphate buffered saline (PBS) & $\begin{array}{l}137 \mathrm{mM} \mathrm{NaCl} \\
2.7 \mathrm{mM} \mathrm{KCl} \\
4.3 \mathrm{mM} \mathrm{Na}_{2} \mathrm{HPO}_{4} \cdot 7 \mathrm{H}_{2} \mathrm{O} \\
1.4 \mathrm{mM} \mathrm{KH}_{2} \mathrm{PO}_{4}, \mathrm{pH} 7.4\end{array}$ \\
\hline 5x SDS electrophoresis buffer & $\begin{array}{l}125 \mathrm{mM} \text { Tris } \\
1.25 \mathrm{M} \text { glycine } \\
0.5 \% \text { SDS, pH } 8.3\end{array}$ \\
\hline 2x SDS-sample buffer & $\begin{array}{l}100 \mathrm{mM} \text { Tris/HCl, } \mathrm{pH} 6.8 \\
4 \% \text { SDS } \\
0.2 \% \text { bromphenol blue } \\
20 \% \text { glycerol } \\
5 \% \beta \text {-mercaptoethanol }\end{array}$ \\
\hline 10x TAE & $\begin{array}{l}0.4 \mathrm{M} \text { Tris acetate } \\
10 \mathrm{mM} \text { EDTA, } \mathrm{pH} 8.3\end{array}$ \\
\hline $0.1 \times \mathrm{TE}$ & $\begin{array}{l}1 \mathrm{mM} \text { Tris } \\
0.1 \mathrm{mM} \text { EDTA, pH } 8.0\end{array}$ \\
\hline 6x DNA sample buffer & $\begin{array}{l}30 \% \text { glycerine } \\
0.25 \% \text { bromphenol blue } \\
0.25 \% \text { Xylene cyanole FF } \\
\mathrm{H}_{2} \mathrm{O}\end{array}$ \\
\hline Tris/HCl & 40 mM Tris, pH 5.0 \\
\hline Alkaline tail lysis buffer & $\begin{array}{l}25 \mathrm{mM} \mathrm{NaOH} \\
0.2 \mathrm{mM} \text { EDTA } \\
\mathrm{H}_{2} \mathrm{O}\end{array}$ \\
\hline
\end{tabular}




\subsubsection{Antibodies}

Table 2.3 List of antibodies used for western blots

\begin{tabular}{|c|c|c|c|c|}
\hline $\begin{array}{l}\text { Antibody } \\
\text { against }\end{array}$ & Source & Provider & Dilution & Catlog number \\
\hline$\beta$-actin & mouse & Sigma & $1: 10000$ & A 5441 \\
\hline HIF-1 $\alpha$ & mouse & Novus Biologicals & $1: 1000$ & NB-100-479 \\
\hline HIF-2a & goat & R\&D Systems & $1: 500$ & AF2997 \\
\hline PHD2 & mouse & Novus Biologicals & $1: 1000$ & NB 100-2219 \\
\hline PHD3 & rabbit & Novus Biologicals & $1: 500$ & NB100-303 \\
\hline \multicolumn{5}{|l|}{$\begin{array}{l}\text { Secondary } \\
\text { antibodies }\end{array}$} \\
\hline rabbit HRP & goat & SantaCruz & $1: 1000$ & Sc-2004 \\
\hline mouse HRP & goat & SantaCruz & $1: 1000$ & Sc-2005 \\
\hline
\end{tabular}

Table 2.4 List of antibodies used for FACS

\begin{tabular}{|ll|}
\hline Antibodies & Provider \\
\hline anti-Alpha5 integrin & Biolegend, London, United Kingdom \\
\hline anti-integrin $\boldsymbol{\beta} 1$ & Biolegend, London, United Kingdom \\
\hline anti-CD11b & BD Bioscience, Heidelberg, Germany \\
\hline anti-Pir-A/B & Biolegend, London, United Kingdom \\
\hline anti-F4/80 & Biolegend, London, United Kingdom \\
\hline Rat IgG2a & Biolegend, London, United Kingdom \\
\hline IgG & Biolegend, London, United Kingdom \\
\hline Rat IgGK1 & Biolegend, London, United Kingdom \\
\hline
\end{tabular}




\subsubsection{Cell culture medium}

Table 2.5 List of cell culture medium

\begin{tabular}{|ll|}
\hline Medium & Composition/Provider \\
\hline Culture medium & DMEM \\
& $10 \%$ FCS \\
& $1 \%$ sodium pyruvate \\
& $1 \%$ HEPES \\
& $0.5 \%$ Penicillin/streptomycin \\
& $1 \%$ L-glutamine \\
\hline DMEM & PAN 'm biotech GmbH, Passau, Germany \\
& \\
\hline Pluznik & DMEM \\
& $10 \%$ FCS \\
& $5 \%$ Horse serum \\
& $30 \%$ L929 conditioned medium \\
& $1 \%$ sodium pyruvate \\
& $0.5 \%$ Penicillin/streptomycin \\
& $\beta$-mercaptoethanol (1:1000) \\
\hline
\end{tabular}

\subsubsection{Primers}

Table 2.6 List of primers used for qRT-PCR

\begin{tabular}{|c|c|c|c|}
\hline mRNA & Primer name & Primer sequence & $\begin{array}{l}\text { Annealing } \\
\text { temperature }\end{array}$ \\
\hline \multirow[t]{2}{*}{ PHD3 } & mPHD3 for & 5'-GGCCGCTGTATCACCTGTAT-3' & $60^{\circ} \mathrm{C}$ \\
\hline & mPHD3 rev & 5'-TTCTGCCCTTTCTTCAGCAT-3' & \\
\hline \multirow[t]{2}{*}{ MS12 } & mS12 for & 5'-GAAGCTGCCAAGGCCTTAGA-3' & $58^{\circ} \mathrm{C}$ \\
\hline & mS12 rev & 5'-AACTGCAACCAACCACCTTC-3' & \\
\hline \multirow[t]{2}{*}{ TNFa } & mTNFa for & 5'-GACCCTCACACTCAGATCATCTTC-3' & $58^{\circ} \mathrm{C}$ \\
\hline & mTNFa rev & 5'-CCACTTGGTGGTTTGCTACGA-3' & \\
\hline \multirow[t]{2}{*}{ iNos } & miNOS for & 5'-AAGTCCAGCCGCACCACCCT-3' & $58^{\circ} \mathrm{C}$ \\
\hline & miNOS rev & 5'-TCCGTGGCAAAGCGAGCCAG-3' & \\
\hline
\end{tabular}




\begin{tabular}{|c|c|c|c|}
\hline Arginase & mArginase for & 5'-AGGACAGCCTCGAGGAGGGG-3' & $58^{\circ} \mathrm{C}$ \\
\hline & mArginase rev & 5'-CCCTGGCGTGGCCAGAGATG-3' & \\
\hline Fizz & mFizz for & 5'-TCCCAGTGAATACTGATGAGA-3' & $54^{\circ} \mathrm{C}$ \\
\hline & mFizz rev & 5'-CCACTCTGGATCTCCCAAGA-3' & \\
\hline PHD1 & mPHD1 for & 5'-GCTAGGCTGAGGGAGGAAGT-3' & $60^{\circ} \mathrm{C}$ \\
\hline & mPHD1 rev & 5'-TCTACCCAGGCAATCTGGTC-3' & \\
\hline PHD2 & PHD2_ex3/5 for & 5'-TTGCTGACATTGAACCCAAA-3' & $58^{\circ} \mathrm{C}$ \\
\hline & PHD2_ex5 rev & 5'-GGCAACTGAGAGGCTGTAGG-3' & \\
\hline PKM2 & mPKM2 for & 5'-AACCGAAGTACGCCCGAGGAC-3' & $58^{\circ} \mathrm{C}$ \\
\hline & mPKM2 rev & 5'-ATCGGGAAGCAGGCCCAATGGT-3' & \\
\hline Pfk & mPfkl for & 5'-ACGAGGCCATCCAGCTCCGT-3' & $59^{\circ} \mathrm{C}$ \\
\hline & mPfkl rev & 5'-TGGGGCTTGGGCAGTGTCCT-3' & \\
\hline Pdk1 & mpdk1 for & 5'-GTTCACGTCACGCTGGGCGA-3' & $66^{\circ} \mathrm{C}$ \\
\hline & mpdk1 rev & 5'-CCAGGCGTCCCATGTGCGTT-3' & \\
\hline Ym-1 & mYm1 for & 5'-GCCAGCAGAAGCTCTCCAGAAGCAA-3' & $59^{\circ} \mathrm{C}$ \\
\hline & mYm1 rev & 5'-ACTGAACGGGGCAGGTCCAAACT-3' & \\
\hline IL-6 & mIL6 for & 5'-GCTGGTGACAACCACGGCCT-3' & $58^{\circ} \mathrm{C}$ \\
\hline & mIL6 rev & 5'-TGCACAACTCTTTTCTCATTTCCACGA -3' & \\
\hline Angptl2 & mAngptl2 for & 5'-ACCTCAACAGGTACAAGCGG-3' & $60^{\circ} \mathrm{C}$ \\
\hline & mAngptl2 rev & 5'-CTCACGATGCCTCCGTCTAC-3' & \\
\hline CD36 & mCD36 for & 5'-GCATCACCCCTCCAGAATCC-3' & $60^{\circ} \mathrm{C}$ \\
\hline & mCD36 rev & 5'-TGGTCCCAGTCTCATTTAGCC-3' & \\
\hline $\begin{array}{l}\text { Primers for } \\
\text { genotype PCR }\end{array}$ & & & \\
\hline
\end{tabular}




\begin{tabular}{|c|c|c|c|}
\hline PHD3 & PHD3 for & 5'-CCACGTTAACTCTAGAGCCACTGA-3' & $58^{\circ} \mathrm{C}$ \\
\hline & PHD3 rev & 5'-ATGGCCGCTGTATCACCTGTAT-3' & \\
\hline LysM-cre & LysMcre for & 5'-GTTCGCAAGAACCTGATGGACA-3' & $60^{\circ} \mathrm{C}$ \\
\hline & LysMcre rev & 5'-GTTCGCAAGAACCTGATGGACA-3' & \\
\hline
\end{tabular}

\subsubsection{Commercial kits}

Table 2.6 List of kits used

\begin{tabular}{|c|c|c|}
\hline Application & Name of the kit & Provider \\
\hline Angptl2 ELISA & $\begin{array}{l}\text { ELISA kit for the detection of } \\
\text { Angptl2 }\end{array}$ & $\begin{array}{l}\text { Uscn Life sciences Inc, Wuhan, } \\
\text { China }\end{array}$ \\
\hline cDNA synthesis & First Strand cDNA synthesis kit & $\begin{array}{l}\text { Fermentas GmbH, St. Leon-Rot, } \\
\text { Germany }\end{array}$ \\
\hline Cytokine detection & $\begin{array}{l}\text { BD catometric Bead array mouse } \\
\text { inflammation kit instruction }\end{array}$ & BD biosciences, Germany \\
\hline PCR & PCR Master Mix K0171 & Thermoscientific \\
\hline real-time PCR & Brilliant II SYBR Green qPCR & Bioline, Luckenwalde, Germany \\
\hline Transcriptome assay & $\begin{array}{l}\text { One-Color Microarray-Based } \\
\text { Gene Expression analysis kit }\end{array}$ & Agilent technologies \\
\hline TUNEL Assay & $\begin{array}{l}\text { In-situ cell death detection kit, } \\
\text { fluorescein }\end{array}$ & $\begin{array}{l}\text { Roche Diagnostics, Mannheim } \\
\text { Germany }\end{array}$ \\
\hline Viability Assay & Calcein-AM cell viability assay & Trevigen \\
\hline
\end{tabular}




\subsubsection{Software}

Table 2.7 List of software used

\begin{tabular}{|lll|}
\hline Program & Application & Source \\
\hline CorelDraw & Image editor & Corel Corporation \\
\hline Image J & Image analysis & Imagej.nih.gov \\
\hline Axio-vision & Image analysis & Carl Zeiss \\
\hline Blast & Sequence alignment & Ncbi.nlm.nih.gov \\
\hline Graphpad Prism & Statistical analysis & GraphPad Software Inc. \\
\hline Multi Gauge & Western blot analysis & Fujifilm Corporation \\
\hline EndNote & Managing of bibliographic & $\begin{array}{l}\text { Thomson, Wintertree Software } \\
\text { Inc. }\end{array}$ \\
\hline BD FCAP Array software $\mathbf{3 . 0}$ & FACS analysis & BD Biosciences \\
\hline BD FACSDiva & FACS analysis & BD Biosciences \\
\hline
\end{tabular}

\subsubsection{Instruments}

Table 2.8 List of instruments used

\begin{tabular}{|lll|}
\hline Application & Name of the instrument & Manufacturer \\
\hline Centrifugation & Centrifuge 5415R & $\begin{array}{l}\text { Eppendorf AG Hamburg, } \\
\text { Germany }\end{array}$ \\
& Centrifuge 5810R & $\begin{array}{l}\text { Eppendorf AG Hamburg, } \\
\text { Germany }\end{array}$ \\
& Micro Centrifuge & $\begin{array}{l}\text { Carl Roth GmbH and Co. KG, } \\
\text { Karlsruhe, Germany }\end{array}$ \\
\hline Cleanbench & HERA safe KS 12 & Thermo Electron Corporation, \\
& & Langenselbold, Germany \\
\hline Flow cytometer & BD FACS Canto Il flowcytometer & BD Biosciences \\
\hline Fluorescence microscope & Axio Observer D1 & Zeiss, Germany \\
\hline Gel Doc & Gene flash UV imager & Syngene bio imaging, UK \\
\hline
\end{tabular}




\begin{tabular}{|c|c|c|}
\hline Heating Block & Block thermo stat BT2000 & Kleinfeld Labortechnik, Germany \\
\hline Incubation shaker & Minitron & $\begin{array}{l}\text { INFORNS HT AG, Bottmingen, } \\
\text { Switzerland }\end{array}$ \\
\hline Incubator for cell culture & CB159 & $\begin{array}{l}\text { Binder GmbH, Tuttlingen, } \\
\text { Germany }\end{array}$ \\
\hline Luminometer & Centro LB 960 & $\begin{array}{l}\text { Berthold Technologies GmbH \& } \\
\text { Co. KG, Bad Wildbad Germany }\end{array}$ \\
\hline Magnetic stirrer & Ikamag® $\mathrm{RH}$ & $\begin{array}{l}\text { IKA Labortech, Staufen, } \\
\text { Germany }\end{array}$ \\
\hline Micro plate reader & Model 680 & Bio-Rad, München, Germany \\
\hline Microscope & Motic® AE30 & TED, Pella Inc, USA \\
\hline $\begin{array}{l}\text { Oxygen-controlled work } \\
\text { station }\end{array}$ & In $\mathrm{ViVO}_{2} 400$ & $\begin{array}{l}\text { Ruskin Technologies, Bridgend, } \\
\text { UK }\end{array}$ \\
\hline PCR cycler & Primus 96 Thermocycler & Peqlab, Erlangen, Germany \\
\hline Photometer & Smart SpecTM Plus & Bio-Rad, München, Germany \\
\hline \multicolumn{3}{|l|}{ Power supply } \\
\hline Real-time PCR cycler & $\mathrm{M} \times 3000 \mathrm{P}$ & Stratagene, La Jolla, USA \\
\hline Rotator & Rotator RS-24 & $\begin{array}{l}\text { G.Kisker GbR, Steinfurt, } \\
\text { Germany }\end{array}$ \\
\hline UV-transilluminator & InGenius & Syngene, Camebridge, UK \\
\hline Vortex & Vortex gemie 2 & Scientific industries, Germany \\
\hline Water bath & Water bath & Medigen, Germany \\
\hline Western blot & $\begin{array}{l}\text { PerfectBlueSemi-Dry } \\
\text { elektroblotter }\end{array}$ & Fujifilm, Düsseldorf, Germany \\
\hline Western blot imaging & LAS 3000 Imager & Fujifilm, Düsseldorf, Germany \\
\hline Western blot transfer & $\begin{array}{l}\text { PerfectBlue Double gel system } \\
\text { Twin }\end{array}$ & Peqlab, Erlangen, Germany \\
\hline
\end{tabular}




\subsection{Methods}

\subsubsection{Myeloid-specific conditional PHD3 knockout $\left(\right.$ PHD3 $\left.^{-/}\right)$mice}

The generation and detailed characterization of $P h d 3^{\text {floxflox }}$ mice were reported previously (Takeda et al., 2006). The mice were kindly provided by Prof. Guo-Hua Fong, Center for Vascular Biology, University of Conneticut Health Center, Farmington, USA. All animals in this study were backcrossed to C57BL/6 mice at least five times. Phd ${ }^{\text {floxfllox }}$ mice were crossed with LysMcre mice (Clausen et al., 1999) to generate Phd3 ${ }^{\text {floxfllox }} \times$ LysMcre $^{+/}$mice within two generations. Phd $3^{\text {floxflox }} \times \mathrm{LysMcre}^{+/}$mice were then crossed with Phd3 ${ }^{\text {floxflox }}$ mice to obtain PHD3 ${ }^{-/}\left(P h d 3^{\text {floxfllox }} \times\right.$ LysMcre $\left.^{+/}\right)$mice and littermate control wt mice (Phd3 floxflox $x$ LysMcre ${ }^{-/}$).

\subsubsection{Isolation of gDNA}

Small pieces of ear/tail clipping from mice were taken in $75 \mu \mathrm{l}$ of alkaline tail lysis buffer. Then the samples were incubated for 1 hour at $95^{\circ} \mathrm{C}$ for tissue lysis and subsequently transferred to $4^{\circ} \mathrm{C}$ for $10 \mathrm{~min} .75 \mu \mathrm{l}$ of $40 \mathrm{mM}$ Tris/HCl buffer was added. Out of this, $5 \mu$ of sample were taken for performing PCR.

\subsubsection{Polymerase chain reaction}

For the amplification of DNA, the well described polymerase chain reaction (PCR) method was used. Genomic DNA from mouse tail was used as template. PCR was performed in a total reaction volume of 25

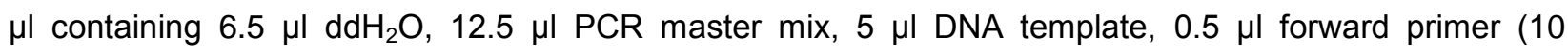
$\mathrm{pmol} / \mu \mathrm{l})$, and $0.5 \mu \mathrm{l}$ reverse primer $(10 \mathrm{pmol} / \mu \mathrm{l})$. The reaction was carried out in the Primus 96 thermocycler. The used PCR cycling parameters are described in Table 2.9. 
Table 2.9 Parameters used for PCR cycling

\begin{tabular}{|lllll|}
\multirow{2}{*}{ Initial denaturation } & Step & Temperature & Duration & Number of cycles \\
\cline { 2 - 5 } PCR & & $95^{\circ} \mathrm{C}$ & $3 \mathrm{~min}$ & 1 \\
\hline \multirow{2}{*}{ Final extension } & Denaturation & $95^{\circ} \mathrm{C}$ & $30 \mathrm{sec}$ & \\
& Annealing & $\mathrm{T}_{\mathrm{m}}$ & $1 \mathrm{~min}$ & 40 \\
\hline & Extension & $72^{\circ} \mathrm{C}$ & $2 \mathrm{~min}$ & \\
\hline
\end{tabular}

\subsubsection{Differentiation and cultivation of bone marrow-derived macrophages}

Bone marrow-derived macrophages (BMDM) are primary macrophages, derived from bone marrow cells in vitro in the presence of colony stimulating and growth factors. Macrophage colony-stimulating factor (M$\mathrm{CSF}$ ) is a lineage-specific growth factor that is responsible for the proliferation and differentiation of committed myeloid progenitors into cells of the macrophage/monocyte lineage.

In this protocol, bone marrow cells were grown in petridishes in the presence of M-CSF, which is secreted by L929 cells and is used in the form of L929-conditioned medium. The efficiency of the differentiation was assessed using fluorescence-activated cell sorting (FACS) analysis of F4/80 surface antigen expression (Weischenfeldt and Porse, 2008). The differentiated BMDMs are suitable for various experiments, for example morphological, gene expression, and physiological analysis.

For the isolation of bone marrow cells mice were sacrificed by cervical dislocation at the age of 8-12 weeks. Bone marrow cells were isolated from the femur by flushing $10 \mathrm{ml}$ of culture medium through the bone. The flushed cells were then cultured on cell culture dishes in culture at $37^{\circ} \mathrm{C}$ and $5 \% \mathrm{CO}_{2}$ in a humidified incubator as described before (Burgess et al., 1985). After 24 hrs non-adherent monocytes were harvested, seeded in pluznik medium and differentiated for 3-8 days. Adherent BMDM were detached with $3.5 \mathrm{ml}$ accutase and resuspended in culture medium. 


\subsubsection{Isolation of RNA}

For RNA isolation $0.7 \times 10^{6} \mathrm{BMDM}$ were seeded in $2 \mathrm{ml}$ culture medium in 6-well plates and incubated for 4, 24 and $48 \mathrm{hrs}$ at $37^{\circ} \mathrm{C}$ and $5 \% \mathrm{CO}_{2}$ in normoxia $\left(20 \% \mathrm{O}_{2}\right)$ or hypoxia $\left(1 \% \mathrm{O}_{2}\right)$ using the In Vivo 400 work station. Cells were washed once with PBS and harvested in $1 \mathrm{ml}$ of Trizol per well. The samples were then collected in a $1.5 \mathrm{ml}$ eppendorf tube and were incubated for $5 \mathrm{~min}$ at room temperature. $200 \mu \mathrm{l}$ of chloroform was added and mixed well by inverting the tubes for 6 times followed by incubation for 3 min. Samples were centrifuged at $12000 \mathrm{xg}$ at $4^{\circ} \mathrm{C}$ for $15 \mathrm{~min}$. Then the aqueous upper layer was transferred into a new eppendorf tube. $500 \mu \mathrm{l}$ isopropanol was added to each sample and vortexed, incubated for $10 \mathrm{~min}$ at room temperature, then again incubated for $10 \mathrm{~min}$ at $-20^{\circ} \mathrm{C}$ and centrifuged at $12000 \mathrm{~g}$ at $4^{\circ} \mathrm{C}$ for $10 \mathrm{~min}$. The supernatant was discarded, the pellet was washed using $1 \mathrm{ml} 75 \%$ ethanol. After centrifuging at $7000 \mathrm{~g} 4^{\circ} \mathrm{C}$ for $10 \mathrm{~min}$, the supernatant was carefully discarded and the pellet was dried. After drying it was dissolved in $15 \mu \mathrm{l}$ of RNase free water. The RNA solution was incubated at $56^{\circ} \mathrm{C}$ for $10 \mathrm{~min}$. Then the samples were stored at $-80^{\circ} \mathrm{C}$.

\subsubsection{RNA concentration measurement}

After RNA isolation, the concentrations of the samples were determined by measuring the absorption at $260 \mathrm{~nm}$ and $280 \mathrm{~nm}$ using the BioAnalyzer. The threshold for a sufficient purity of RNA samples was determined by the $260 \mathrm{~nm} / 280 \mathrm{~nm}$ ratio of 1.8 , presence of proteins in the samples decreases the ratio.

\subsection{7 cDNA synthesis}

The ability to synthesize DNA from an RNA template, using reverse transcriptase is explored for the process of cDNA synthesis. $1 \mu \mathrm{g}$ of RNA was used for the synthesis of cDNA using the First strand cDNA synthesis kit. For the synthesis of cDNA a mixture of $11 \mu$ l consisting of $1 \mu \mathrm{g} \mathrm{RNA}, \mathrm{H}_{2} \mathrm{O}$ and $1 \mu \mathrm{l}$ Oligo-dT was prepared and incubated for $65^{\circ} \mathrm{C}$ for $5 \mathrm{~min}$ then the samples were immediately transferred onto ice for $5 \mathrm{~min}$. To each of the tubes a $9 \mu \mathrm{l}$ mastermix composed of $2 \mu \mathrm{l}$ dNTP, $1 \mu \mathrm{l}$ Ribolock, $2 \mu \mathrm{l}$ reverse transcriptase, and $4 \mu \mathrm{RT}$ buffer was added. The samples were incubated at $37^{\circ} \mathrm{C}$ for one hour. The reaction was stopped by inactivating the reverse transcriptase by incubating at $70^{\circ} \mathrm{C}$ for $5 \mathrm{~min}$. 


\subsubsection{Quantitative real-time PCR}

A quantitative real-time polymerase chain reaction ( $q R T-P C R$ ) is a PCR technique, which is used to amplify and simultaneously quantify a DNA template. In quantitative PCR, the amount of the amplified product is linked to fluorescence intensity using a fluorescent reporter molecule, a DNA-intercalating dye that glows once it binds to double-stranded DNA. An increase in DNA product during PCR therefore leads to an increase in fluorescence intensity and is measured at each cycle, thus allowing DNA concentrations to be quantified. However, dsDNA dyes such as SYBR Green will bind to all dsDNA PCR products, including nonspecific PCR products (such as Primer dimer). This can potentially interfere with, or prevent, accurate quantification of the intended target sequence. As a reference dye $\mathrm{ROX}^{\mathrm{TM}}$ was added to the samples to normalize the fluorescence signal intensity between the reactions. With reference to a standard dilution, the dsDNA concentration in the PCR can be determined. The quantification can be either is done by an absolute number of copies or a relative amount when normalized to DNA input or additional normalizing genes using any housekeeping gene. This quantitation approach is termed the comparative $C_{t}$ method. $C_{t}$ (threshold cycle) is a relative measure of the concentration of target in the PCR reaction. This method of analysis involves comparing the Ct values of the samples of interest with a control or calibrator such as a non-treated sample or RNA from normal tissue. The Ct values of both the calibrator and the samples of interest are normalized to an appropriate endogenous housekeeping gene.

Transcript levels were analyzed by qRT-PCR with the Brilliant II SYBR Green qPCR Master Mix in an MX3005Pro light cycler. For the reaction $1 \mu \mathrm{l}$ cDNA, $12.5 \mu \mathrm{l}$ SYBR Advantage qPCR Premix (2x), $0.5 \mu \mathrm{l}$ forward primer $(10 \mu \mathrm{M}), 0.5 \mu \mathrm{l}$ reverse primer $(10 \mu \mathrm{M})$ and $0.5 \mu \mathrm{l}$ ROX reference dye LMP were mixed and $\mathrm{dH}_{2} \mathrm{O}$ added to a total volume of $25 \mu \mathrm{l}$. The condition of the reaction is described in table 2.10 
Table 2.10 Parameters used for qRT-PCR cycling

\begin{tabular}{|c|c|c|c|c|}
\hline & Step & Temperature & Duration & Cycles \\
\hline Denaturation & Denaturation & $95^{\circ} \mathrm{C}$ & $30 \mathrm{sec}$ & 1 \\
\hline \multirow{3}{*}{ PCR } & Denaturation & $95^{\circ} \mathrm{C}$ & $10 \mathrm{sec}$ & \multirow{3}{*}{40} \\
\hline & Annealing & $\mathrm{T}^{\circ} \mathrm{C}$ & $20 \mathrm{sec}$ & \\
\hline & Extension & $72^{\circ} \mathrm{C}$ & $20 \mathrm{sec}$ & \\
\hline \multirow{3}{*}{$\begin{array}{l}\text { Amplification of } \\
\text { the dissociation } \\
\text { curve }\end{array}$} & Denaturation & $95^{\circ} \mathrm{C}$ & $1 \mathrm{~min}$ & \multirow{3}{*}{1} \\
\hline & Annealing & $\mathrm{T}_{\mathrm{m}}{ }^{\circ} \mathrm{C}$ & $30 \mathrm{sec}$ & \\
\hline & Extension & $72^{\circ} \mathrm{C}$ & $30 \mathrm{sec}$ & \\
\hline
\end{tabular}

\subsubsection{Protein extraction}

For protein extraction $4 \times 10^{6}$ cells were seeded in $10 \mathrm{ml}$ culture medium in tissue culture grade petridishes and incubated for $24 \mathrm{hrs}$ at $37^{\circ} \mathrm{C}$ and $5 \% \mathrm{CO}_{2}$ in normoxia $\left(20 \% \mathrm{O}_{2}\right)$ or hypoxia $\left(1 \% \mathrm{O}_{2}\right)$. For harvesting, the cells were washed once with PBS and $175 \mu$ l of lysis buffer were added to each $10 \mathrm{~cm}$ dish. An EDTAfree protease-inhibitor was added to the lysis buffer to prevent protein degradation. The cells were scraped from the dishes and the cell lysate was transferred into a $1.5 \mathrm{ml}$ eppendorf tube. The samples were placed on ice for about $10 \mathrm{~min}$. The lysed cells were pelleted by centrifugation at $12000 \mathrm{rpm}$ for 20 min at $4^{\circ} \mathrm{C}$ and the supernatant was transferred into a new $1.5 \mathrm{ml}$ eppendorf tube. The protein concentration was measured by performing a Bradford protein concentration assay.

\subsubsection{Bradford Protein concentration assay}

The Bradford protein concentration assay, a colorimetric protein assay, is based on an absorbance shift of the dye Coomassie Brilliant Blue G-250. During this assay under acidic conditions the red form of the dye is converted into its bluer form upon binding to the protein. Under acidic conditions, the dye is 
predominantly in the doubly protonated red cationic form which has an maximum absorbance at $470 \mathrm{~nm}$. When the dye binds to proteins, it is converted to a stable unprotonated blue form which has an absorbance at $595 \mathrm{~nm}$ (Compton and Jones 1985). The linear range of Bradford assay is from $0 \mu \mathrm{g} / \mathrm{ml}$ to $2000 \mu \mathrm{g} / \mathrm{ml}$. A standard curve was prepared from a series of standards between $0.5 \mu \mathrm{g}$ and $5 \mu \mathrm{g}$ bovine serum albumin (BSA). For the Bradford assay, $1 \mu \mathrm{l}$ of the sample was added to $200 \mu \mathrm{l}$ of 1:5 times diluted Protein Assay Reagent from Bio-Rad and the absorbance was measured at $595 \mathrm{~nm}$. The concentration of the unknown protein samples was determined using the standard curve.

\subsubsection{SDS-Polyacrylamide gel electrophoresis (PAGE)}

Polyacrylamide gel electrophoresis (PAGE) is a technique to separate biological macromolecules for example proteins or nucleic acids according to their molecular weight. To eliminate the effect of folding structures, proteins are treated with sodium dodecyl sulphate (SDS), an anionic detergent, to denaturate the protein by breaking the secondary and non-disulfide-linked tertiary structures. SDS additionally applies a negative charge to each protein in proportion to its mass. The negative charge of the proteins by SDS makes the proteins run towards the positive electrode during electrophoresis. The reducing agent $\beta$ mercaptoethanol further denatures the proteins by reducing disulfide linkages and breaking up quaternary protein structures. The sample buffer contains a tracking dye which has a higher electrophoretic mobility than the analytes to allow the experimenter to track the progress of the solution through the gel during the electrophoretic run. The preparation of a gel needs two different layers of acrylamide. The lower layer resolving gel is responsible for actually separating polypeptides by size. The upper layer stacking gel has the sample wells, it sweeps up the sample that they are compressed into micrometer thin layers when they reach the separating gel to have a uniform start before the separation. The $\mathrm{pH}$ conditions in the stacking gel result in the samples to stack between the fast migrating chloride ions and the slower migrating glycine from the sample buffer at the starting point above the resolving gel. Usually $10-12 \%$ of acrylamide is used for the preparation of the gel.

Double the volume of SDS sample buffer was added to $80-100 \mu \mathrm{g}$ of protein. Before loading the samples to the $12 \%$ SDS polyacrylamide gel, the samples were boiled at $95^{\circ} \mathrm{C}$ for $10 \mathrm{~min}$. The prestained 
PageRuler ${ }^{\mathrm{TM}}$ marker was loaded along with the samples onto the gel. The electrophoresis was run at a constant current of $40-45 \mathrm{~mA}$ with maximum voltage set at $300 \mathrm{~V}$.

Table 2.11 Composition of stacking and resolving gel

\begin{tabular}{|c|c|c|c|}
\hline & Stacking gel & Resolving gel $10 \%$ & Resolving gel $12 \%$ \\
\hline $\mathrm{H}_{2} \mathrm{O}$ & $6.8 \mathrm{ml}$ & $11.9 \mathrm{ml}$ & $9.9 \mathrm{ml}$ \\
\hline $30 \%$ acrylamide mix & $1.7 \mathrm{ml}$ & $10 \mathrm{ml}$ & $12 \mathrm{ml}$ \\
\hline $1 \mathrm{M}$ Tris pH6.8 & $1.25 \mathrm{ml}$ & - & - \\
\hline 1.5 M Tris pH8.8 & - & $7.5 \mathrm{ml}$ & $7.5 \mathrm{ml}$ \\
\hline $\begin{array}{l}10 \% \text { ammonium } \\
\text { persulfate }\end{array}$ & $1 \mathrm{ml}$ & $0.3 \mathrm{ml}$ & $0.3 \mathrm{ml}$ \\
\hline $10 \%$ SDS & $1 \mathrm{ml}$ & $0.3 \mathrm{ml}$ & $0.3 \mathrm{ml}$ \\
\hline TEMED & $0.01 \mathrm{ml}$ & $0.012 \mathrm{ml}$ & 0.12 \\
\hline
\end{tabular}

\subsubsection{Western blot Development}

The separated proteins on the gel were transferred onto a nitrocellulose membrane. For transfer of proteins, the gel and the nitrocellulose membrane were equilibrated in western blot transfer buffer. The gel and the nitrocellulose membrane were then sandwiched between filter papers already soaked in blotting buffer. The transfer was performed using PerfectBlue Semi-Dry Electroblotter with a constant current setting of $2 \mathrm{~mA} / \mathrm{cm}^{2}$ for 1 hour. The membrane was analyzed for the protein expression of interest by using primary antibody against it. The primary antibodies were then detected by horseradish peroxidase conjugated secondary antibodies which are raised against the Fc region of the primary antibody.

After transfer the membrane was washed with PBS for $10 \mathrm{~min}$. Then the confirmation of the quality of transfer was controlled by Ponceau S staining. The membrane was washed three times with PBS to get rid of the Ponceau S staining. The blot was blocked with 5\% milk in PBS for 1 hour at room temperature to prevent unspecific binding of the antibodies. Dilution of the primary antibody was prepared in PBS 
containing $5 \%$ non fat milk and was applied on to the blot and incubated overnight at $4^{\circ} \mathrm{C}$. The used dilutions of the antibodies are listed in Tab. 2.3.

After overnight incubation of the primary antibody at $4^{\circ} \mathrm{C}$, the membrane was washed thrice for 10 min with PBS. The secondary antibody which is conjugated to horseradish peroxidase is diluted in PBS containing $5 \%$ non fat milk. The membrane was incubated in secondary antibody for $2 \mathrm{hrs}$ at room temperature. The membrane was washed three times with PBS for 10 min each. $10 \mathrm{ml}$ of ECL solution was applied on to the membrane for development. The blot was developed by exposing the membrane onto X-ray films or was imaged using the LAS3000 Imager from Fujifilm for different exposure times.

\subsubsection{TUNEL ASSAY}

Terminal deoxynucleotidyl transferase dUTP nick end labeling (TUNEL) assay detects DNA fragmentations by labeling the terminal end of nucleic acids. The hallmark of apoptosis is DNA degradation, which in early stages, is selective to the internucleosomal DNA linker regions. The DNA cleavage may yield double-stranded and single-stranded DNA breaks (nicks). Both types of breaks can be detected by labeling the free $3^{\prime}-\mathrm{OH}$ terminal with modified nucleotides (e.g., biotin-dUTP, DIG-dUTP, fluorescein-dUTP) in an enzymatic reaction. The enzyme terminal deoxynucleotidyl transferase (TdT) catalyzes the template-independent polymerization of deoxyribonucleotides to the 3 '-end of single- and double-stranded DNA.

$0.5 \times 10^{6}$ BMDM were seeded in 6-well plates on coverslips in $2 \mathrm{ml}$ culture medium and were incubated for $48 \mathrm{hrs}$ at $37^{\circ} \mathrm{C}$ and $5 \% \mathrm{CO}_{2}$ in normoxia $\left(20 \% \mathrm{O}_{2}\right)$ or hypoxia $\left(1 \% \mathrm{O}_{2}\right)$. The cells were then washed with PBS and fixed using 4\% PFA for $20 \mathrm{~min}$. The cells were permeabilized using $0.1 \%$ TritonX-100 in freshly prepared $0.1 \%$ sodium citrate for $2 \mathrm{~min}$ on ice and were then stained for $60 \mathrm{~min}$ at $37^{\circ} \mathrm{C}$ in a dark and moist chamber using enzyme and labelling solution provided by the fluorescein in-situ cell death detection kit. Cells treated with DNAse served as positive control. The cells were then washed with PBS and were imaged using the Axio Observer fluorescence microscope. 


\subsubsection{Annexin V Staining}

Phospholipids of the cell membrane are asymmetrically distributed between the inner and outer leaflets of the membrane. Phosphatidylcholine and sphingomyelin are exposed on the external leaflet of the lipid bilayer, while phosphatidylserine is located on the inner surface. During apoptosis, this asymmetry is disrupted and phosphatidylserine becomes exposed on the outside surface of the plasma membrane. Because the anticoagulant protein Annexin $\mathrm{V}$ binds with high affinity to phosphatidylserine, the fluorochrome-conjugated Annexin V can been used to detect apoptotic cells by flow cytometry.

BMDM were seeded in $35 \mathrm{~mm}$ dishes in culture medium with and without serum. After $48 \mathrm{hrs}$ the cells were detached using accutase for $15 \mathrm{~min}$ and cells were counted. $1.5 \times 10^{6}$ cells per sample were subsequently analyzed. After washing with PBS cells were stained with Annexin V and propidium iodide for 20 min at $4 \stackrel{\circ}{ } \mathrm{C}$. Then the cells were resuspended in Annexin $\mathrm{V}$ binding buffer and were anlysed using the BD FACS Canto flow cytometer. In some experiments, cells were treated with $100 \mu \mathrm{M}$ S-Nitroso-NAcetyl-D,L-Penicillamine (SNAP) or $500 \mathrm{nM}$ staurosporine or 5-10 $\mu \mathrm{g} / \mathrm{ml}$ LPS for $12 \mathrm{hrs}$.

\subsubsection{Flow cytometry}

Flow cytometry is a laser-based method for cell counting, cell sorting, biomarker detection and protein engineering, by suspending cells in a stream of fluid and passing them by an electronic detection apparatus. It allows simultaneous multiparametric analysis of the physical and chemical characteristics of up to thousands of particles per second. Fluorescence-activated cell sorting (FACS) is a specialized type of flow cytometry. It provides a method for sorting a heterogeneous mixture of biological cells into two or more containers, one cell at a time, based upon the specific light scattering and fluorescent characteristics of each cell. FACS provides fast, objective and quantitative recording of fluorescent signals from individual cells as well as physical separation of cells of particular interest. A wide range of fluorophores can be used as labels in flow cytometry.

$0.5 \times 10^{6}$ cells were cultured in $35 \mathrm{~mm}$ petridishes for 24 and $48 \mathrm{hrs}$ at $37^{\circ} \mathrm{C}$ and $5 \% \mathrm{CO}_{2}$ in normoxia $(20 \%$ $\mathrm{O}_{2}$ ) or hypoxia $\left(1 \% \mathrm{O}_{2}\right) \cdot 0.2 \times 10^{6}$ cells were taken in a FACS tube for further analysis. Then the cells were washed with PBS and were incubated with anti-Pir-A/B, anti-F4/80, anti-integrin $\alpha 5$, anti-integrin $\beta 1$, anti- 
CD11b and the respective control antibodies rat $\lg G \mathrm{k} 1$, rat $\lg G 2 \mathrm{a}, \lg G$ for $20 \mathrm{~min}$ at $4^{\circ} \mathrm{C}$. After washing with PBS cells were resuspended in $100 \mu \mathrm{l}$ of binding buffer and analyzed using the flow cytometer.

\subsubsection{Calcein-AM cell viability assay}

Calcein-AM is a non-fluorescent, hydrophobic compound that easily permeates intact, living cells. The hydrolysis of Calcein-AM by intracellular esterase produces calcein, a hydrophilic, strongly fluorescent compound that is well-retained in the cell cytoplasm. Cells, preferably grown in black-walled plates, can be stained and quantified in less than two hrs. $0.2 \times 10^{5}$ cells were grown in $200 \mu$ l of culture medium in black walled 96 well plates for $4,12,24$ and $48 \mathrm{hrs}$ at $37^{\circ} \mathrm{C}$ at $20 \% \mathrm{O}_{2}$ or $1 \% \mathrm{O}_{2}$. The cell viability was determined using the Calcein-AM cell viability assay kit. Before measurement, the plate was taken out from $37^{\circ} \mathrm{C}$ and was centrifuged at $250 \mathrm{~g}$ for $5 \mathrm{~min}$. Supernatant was discarded and $100 \mu \mathrm{l}$ of $1 \mathrm{X}$ calcein AM DW buffer was added to each well. Then again the plate was centrifuged at $250 \mathrm{~g}$ for $5 \mathrm{~min}$. The calcein AM DW buffer was removed and $50 \mu \mathrm{l}$ of fresh calcein AM DW buffer was added. To each well, 50 $\mu \mathrm{l}$ of freshly diluted $2 \mathrm{X}$ AM working solution was added. The plate was then incubated for $30 \mathrm{~min}$ at $37^{\circ} \mathrm{C}$. The fluorescence was measured using a $490 \mathrm{~nm}$ excitation filter and a $520 \mathrm{~nm}$ emission filter. The fluorescence intensity is proportional to the number of viable cells.

\subsubsection{Angptl2 ELISA}

The enzyme-linked immunosorbent assay (ELISA) is a method which uses antibodies to identify a specific substance. Antigens from the sample are attached to a surface coated with a specific antibody. A second antibody is linked to an enzyme, and, in the final step, a substance containing the enzyme's substrate is added. The subsequent reaction produces a detectable signal, most commonly a color change in the substrate. The microtiter plate had been pre-coated with an antibody specific to Angpt|2. Standards and samples were then added to the appropriate microtiter plate wells with a biotin-conjugated antibody specific to Angptl2. Then Avidin conjugated to horseradish peroxidase (HRP) was added to each micro plate well. After 3,3',5,5'-Tetramethylbenzidine(TMB) substrate solution is added, only those wells that contain Angptl2, biotin-conjugated antibody and enzyme-conjugated Avidin exhibited a change in color. The enzyme-substrate reaction is terminated by the addition of sulphuric acid solution and the color 
change is measured spectrophotometrically at a wavelength of $450 \mathrm{~nm} \pm 10 \mathrm{~nm}$. The concentration of Angptl2 in the samples is then determined by comparing the O.D. of the samples to the standard curve. $0.75 \times 10^{6}$ cells were grown in $200 \mu$ l of culture medium in black walled 6 well plates for 4,12 , 24, and 48 hrs at $37^{\circ} \mathrm{C}$ at $20 \% \mathrm{O}_{2}$ or $1 \% \mathrm{O}_{2}$. The supernatant was harvested for the ELISA. $100 \mu \mathrm{l}$ of prepared standards or samples were added to a 96 well coated plate. The wells were then incubated for 2 hrs at $37^{\circ} \mathrm{C}$. The supernatant was then discarded and $100 \mu \mathrm{l}$ of detection reagent $\mathrm{A}$ was added. The wells were then incubated for 1 hour at $37^{\circ} \mathrm{C}$. The supernatant was again discarded and the wells were washed three times with washing buffer. Then $100 \mu$ of detection reagent B was added. The wells were then incubated for $30 \mathrm{~min}$ at $37^{\circ} \mathrm{C}$. The supernatant was discarded and the wells were washed five times with washing buffer. $90 \mu \mathrm{l}$ of substrate solution were added and incubated for $15-25 \mathrm{~min}$ at $37^{\circ} \mathrm{C}$. $50 \mu \mathrm{l}$ of stop solution were added and the absorbance of the samples was measured at $450 \mathrm{~nm}$ using a micro plate reader.

\subsubsection{Transcriptome screen}

A microarray chip consists of DNA spots on a solid chip. It is used to measure the expression of a large number of genes simultaneously. Each spot on a microarray contains multiple identical strands of DNA. The DNA sequence on each spot is unique and represents one gene. Thousands of spots are arrayed in orderly rows and columns on a solid surface. The precise location and sequence of each spot is recorded in a computer database. Microarrays can be the size of a microscope slide, or even smaller. Probe-target hybridization is usually detected and quantified by detection of fluorophore-, or chemiluminescencelabeled targets to determine relative abundance of nucleic acid sequences in the target.

$0.7 \times 10^{6} \mathrm{BMDM}$ were seeded in $2 \mathrm{ml}$ culture medium in 6 -well plates and incubated for $48 \mathrm{hrs}$ at $37^{\circ} \mathrm{C}$ and $5 \% \mathrm{CO}_{2}$ in $20 \% \mathrm{O}_{2}$ or $1 \% \mathrm{O}_{2}$. Cells were washed once with PBS and harvested in Trizol. RNA was isolated (section 2.2.5) and $1 \mu \mathrm{g}$ RNA was transcribed using the First Strand cDNA Synthesis Kit (section 2.2.7). RNA integrity was determined (section 2.2.6). RNA was then added to the Spike mix provided with the Agilent Technologies, One-Color Microarray-Based Gene Expression analysis kit. Samples were then labeled according to the Agilent - Low Input Quick Amp Labeling, one color protocol. cDNA was synthesized from the labeled mRNA. Amplified RNA (aRNA) was then synthesized using T7 RNA polymerase enzyme. Quantification of the labeled aRNA was done before hybridization onto the 
microarray slides. The hybridization was then carried out on the Agilent Microarray Hybridization slide at $65^{\circ} \mathrm{C}$ for $17 \mathrm{hrs}$. All subsequent steps were followed as instructed by Low Input Quick Amp Labeling protocol. The whole transcriptome screen and analysis of the raw data was performed in collaboration with the Transkriptions Analyse Labor (TAL, University Medical Center Göttingen).

\subsubsection{Statistics}

All the statistical evaluations were performed using graph pad prism 4 software. Statistical analyses were performed using Student's two-tailed t-test. Data are shown as means \pm SD. Values of $p<0.05$ were considered statistically significant. Alpha level was set to 0.05 , $p$ values are: ${ }^{*} p<0.05,{ }^{* *} p<0.01,{ }^{* * *} p<$ 0.001 . 


\section{Results}

\subsection{Generation of myeloid-specific PHD3 knockout mice}

The results of the study are in part published (Swain et al., 2014). Figures of the publication are also used in part for the thesis. The goal of my study was to characterize and investigate the role of PHD3 in BMDM. In my experiments I used a conditional PHD3-deficient mouse model. The PHD3 knockout (referred to as $\mathrm{PHD}^{-/}$) mouse model was established by using PHD3 ${ }^{\text {floxflox }}$ mice, in which exon 2 of the PHD3 gene was flanked by loxP sites (Fig. 9). PHD3 ${ }^{\text {flox/llox }}$ mice were crossed with M lysozyme Cre (LysMCre) mice which express the Cre recombinase under the control of the mouse lysozyme $\mathrm{M}$ gene regulatory region. This cross generates littermates that had either no copies $\left(\mathrm{PHD}^{\text {floxfllox }} \times\right.$ LysMCre $^{-/}$) or one copy of the Cre rebombinase $\left(\mathrm{PHD}^{\text {floxfllox }} \times\right.$ LysMCre $\left.^{+-}\right)$. $\mathrm{PHD}^{\text {floxflox }} \times$ LysMCre $^{+/-}$mice have a reduced PHD3 expression in the myeloid cell lineage (monocytes, mature macrophages and granulocytes).

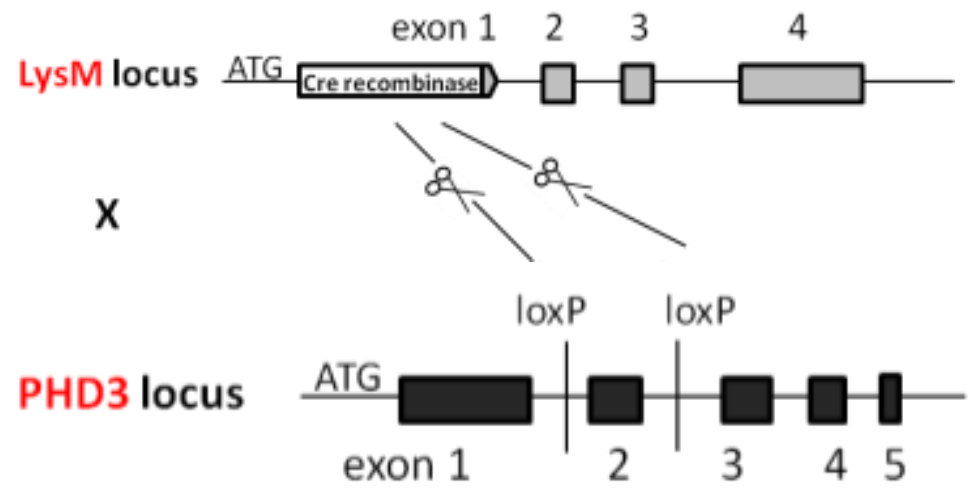

Figure 9: Myeloid-specific PHD3-deficient mouse line generation scheme

Myeloid-specific PHD3-deficient mice were generated by crossing PHD3 ${ }^{\text {floxflox }}$ mice, in which exon 2 is flanked by loxP (flox) sites, with mice expressing the Cre recombinase under control of the lysozyme (LysM) gene regulatory region.

Littermates were genotyped by performing PCRs with gDNA (Fig. 10) to confirm the presence of the loxP sites within the PHD3 gene (product size $840 \mathrm{bp}$ and $400 \mathrm{bp}$ in floxed and wt mice, respectively) and to determine the presence or absence of the Cre recombinase (product size $700 \mathrm{bp}$ and $350 \mathrm{bp}$ in cre positive and wt mice, respectively). 

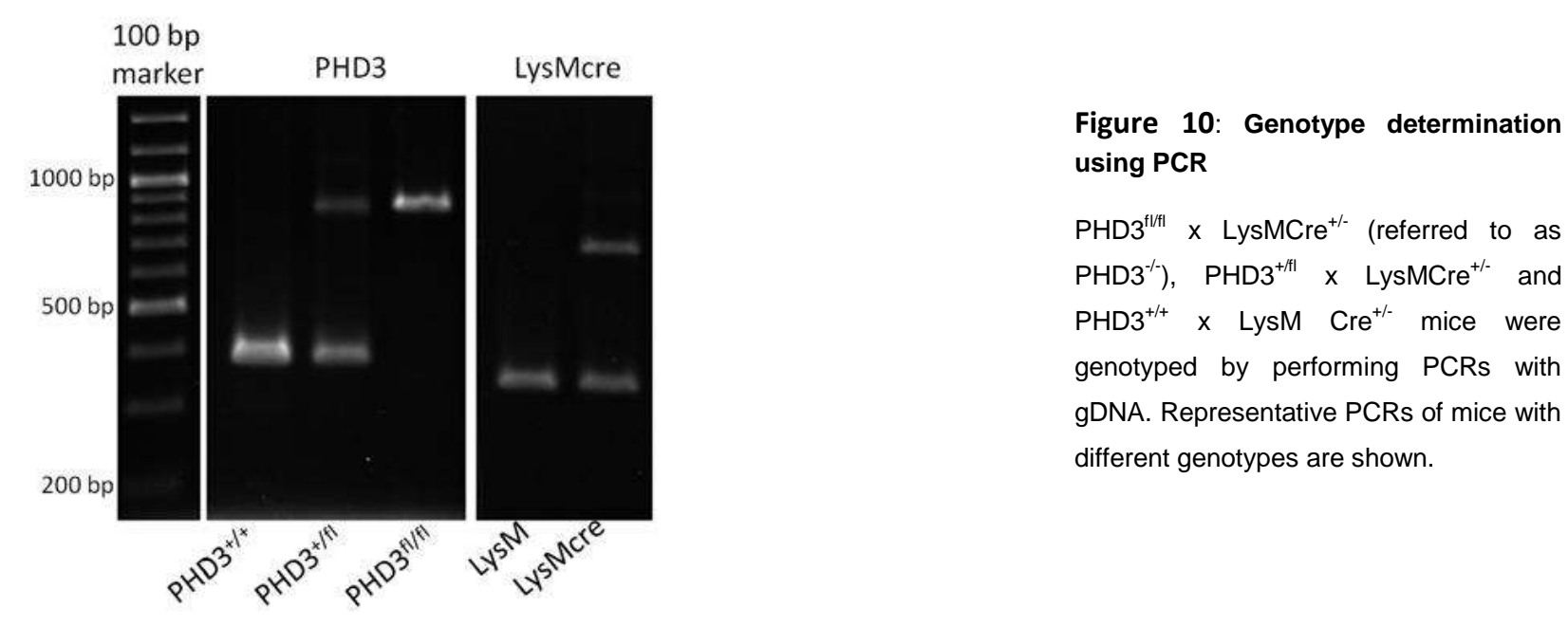
gDNA. Representative PCRs of mice with different genotypes are shown.

\subsection{Consequences of a PHD3 deficiency in macrophages for their differentiation and morphology}

It has been shown earlier by Kiss et al that the macrophage differentiation process of bone marrow cells was altered in BMDM isolated from constitutive PHD3 knockout mice over time (Kiss et al., 2012). To investigate if the conditional knockout of PHD3 also influences the differentiation of macrophages over time, bone marrow cells of both genotypes, i.e. wt and $\mathrm{PHD}^{-/}$were differentiated to mature macrophages with M-CSF conditioned medium. To quantify the differentiation efficacy of the macrophages over time, the cells were stained with anti-F4/80 and anti-CD11b antibodies and analyzed using flow cytometry. F4/80 is a marker for mature macrophages. CD11b marks cells that originated from the monocyte population and neutrophils. The macrophage differentiation process of bone marrow cells was indeed altered in wt and $\mathrm{PHD}^{-/-}$cells over time. $\mathrm{PHD}^{-/-}$bone marrow cells differentiated at earlier time points, i.e. day 3,4 and 5, demonstrated by elevated numbers of F4/80 and CD11b positive cells (Fig. 11). 8 days after starting the differentiation the difference was no longer detectable and cells of both genotypes were fully differentiated. 

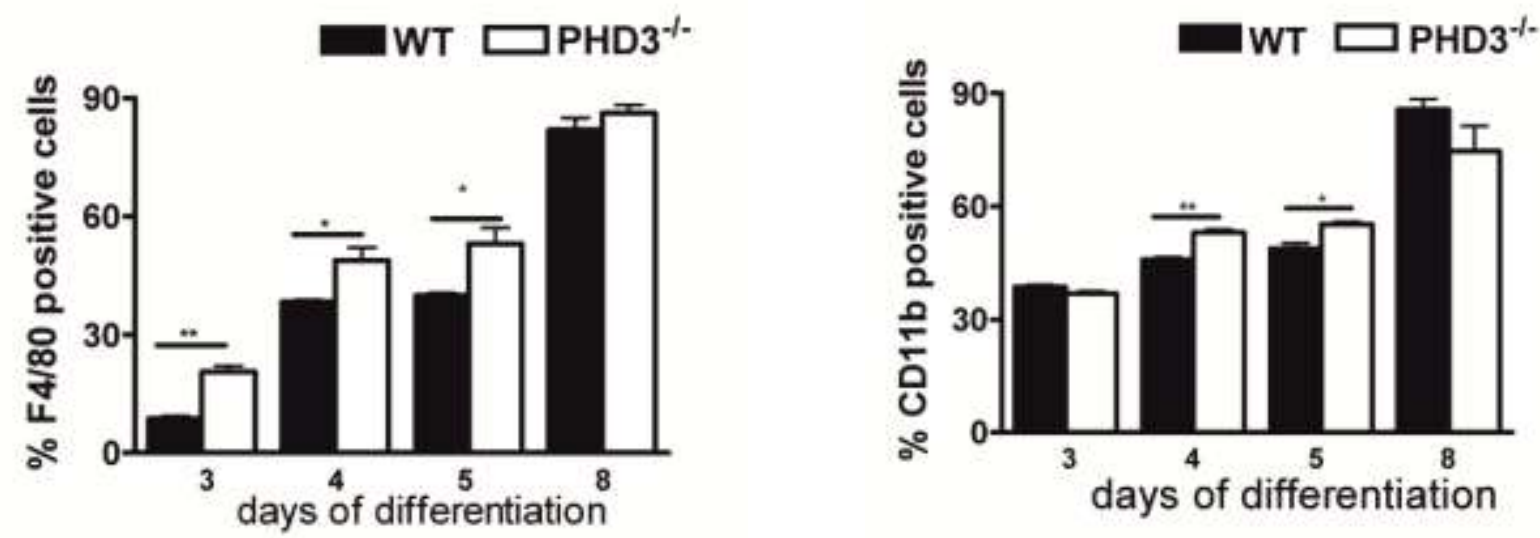

Figure 11: Differentiation of wt and $\mathrm{PHD3}^{-/}{ }^{-1 M D M}$ over time

Macrophages were differentiated from bone marrow cells of $8-12$ weeks old wt and PHD3 ${ }^{-/}$mice using M-CSF containing medium over 3-8 days. PHD3-deficiency in myeloid cells promoted the differentiation of BMDM as shown by F4/80 and CD11b-stainings using FACS analysis. Shown are mean values $\pm S D, n=3,{ }^{*} p<0.05,{ }^{* *} p<0.01$.

To study if the knockout of PHD3 in macrophages affects the morphology of the macrophages, cell staining was performed. Cells isolated from both wt and $\mathrm{PHD}^{-/-}$mice were differentiated over 3 or 8 days with M-CSF conditioned medium. After 3 or 8 days of differentiation the cells were stained with phalloidin (F-actin marker) and DAPI (nucleus marker) (Fig. 12). The cells were then imaged using a fluorescence microscope for morphological differences. Bone marrow cells of both genotypes differentiated to mature macrophages and showed no obvious difference in cell morphology after 3 or 8 days of differentiation. In all subsequent experiments, if not stated otherwise, BMDM, which were differentiated for 8 days, were used. 

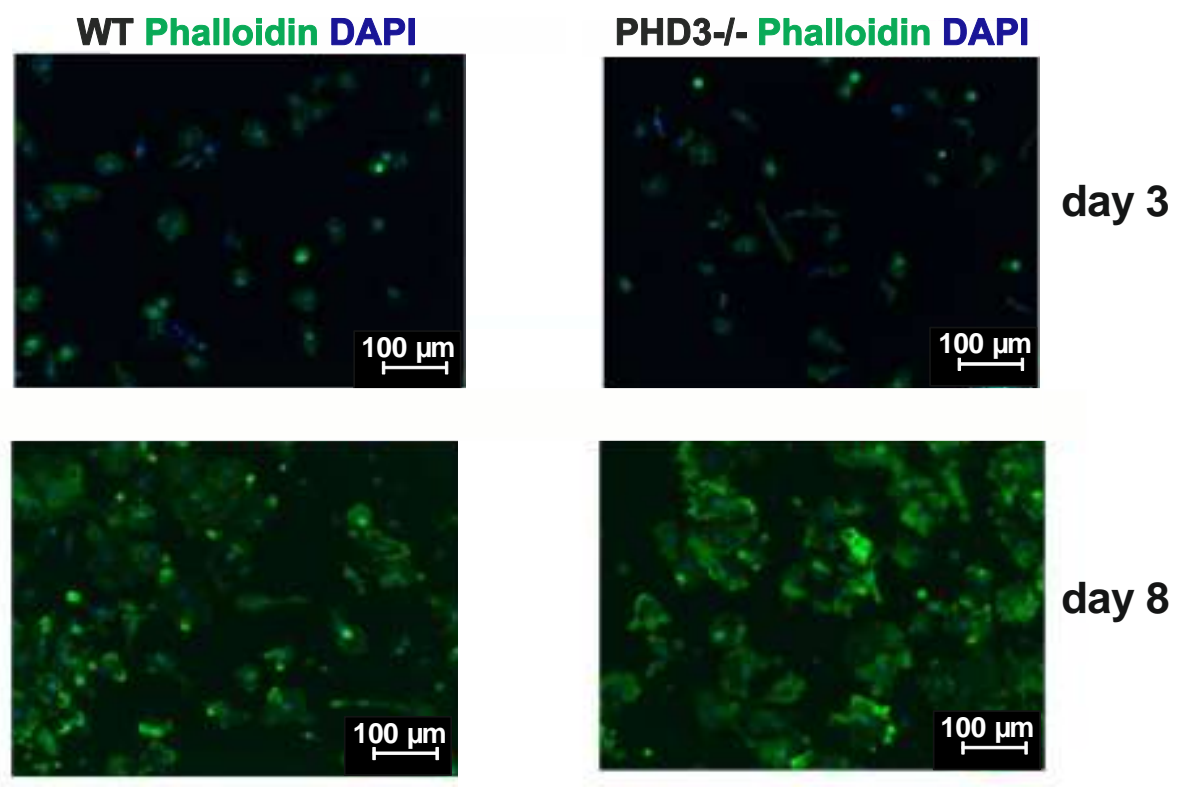

day 8

Figure 12: Morphology of wt and $\mathrm{PHD}^{-/}$BMDM during differentiation

Wt and $\mathrm{PHD}^{-/}$BMDM were differentiated for 3 or 8 days with M-CSF conditioned medium. Subsequently, cells were stained with phalloidin and DAPI. PHD3-deficiency in myeloid cells did not affect the morphology of the cells.

\subsection{Consequences of PHD3-deficiency for macrophage gene expression}

To confirm the knockout of PHD3 and gain insight into the knockout efficiency, qRT-PCRs were performed. Wt and $\mathrm{PHD}^{-/}$BMDM were incubated in normoxia $\left(20 \% \mathrm{O}_{2}\right)$ or hypoxia $\left(1 \% \mathrm{O}_{2}\right)$ for 24 hrs. Subsequently, the mRNA expression level of PHD3 was analyzed (Fig. 13). The hypoxic induction of PHD3 is in line with the literature and is part of a negative feedback mechanism to limit the acute hypoxic response (Stiehl et al., 2006). PHD3 ${ }^{-/-}$BMDM showed a 75\% and 60\% reduction of PHD3 RNA levels in normoxia and hypoxia respectively. Thus, in hypoxia the knockout efficiency was still maintained even after the induction of PHD3

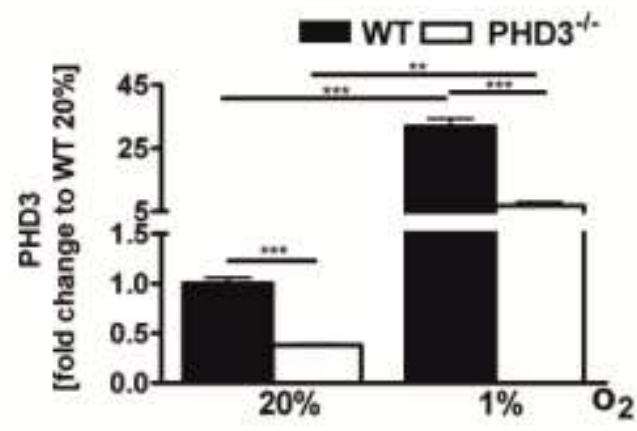

Figure 13: PHD3 mRNA expression of wt and $\mathrm{PHD}^{-/-}$macrophages

PHD3 RNA levels were quantified in BMDM isolated from wt and PHD3 ${ }^{-1-}$ mice and exposed to $20 \%$ or $1 \% \mathrm{O}_{2}$ for $24 \mathrm{hrs}$. Shown are mean values \pm $\mathrm{SD}, \mathrm{n}=3,{ }^{* *} \mathrm{p}<0.01,{ }^{* * *} \mathrm{p}<0.001$. 
The mRNA expression of the other two isoforms of PHDs, i.e. PHD1 and PHD2 was investigated to analyze if the knockout of PHD3 affects their expression. qRT-PCR was performed with samples obtained from wt and $\mathrm{PHD}^{-/-}$BMDM, which were incubated in normoxia $\left(20 \% \mathrm{O}_{2}\right)$ or hypoxia $\left(1 \% \mathrm{O}_{2}\right)$ for 24 hrs (Fig. 14). Comparable to PHD3, PHD2 is inducible in hypoxia. This effect was observed in wt and PHD3 ${ }^{-/}$ BMDM. In none of the conditions analyzed there was a difference when comparing PHD1 and PHD2 RNA levels in wt versus $\mathrm{PHD}^{-/-}$BMDM.
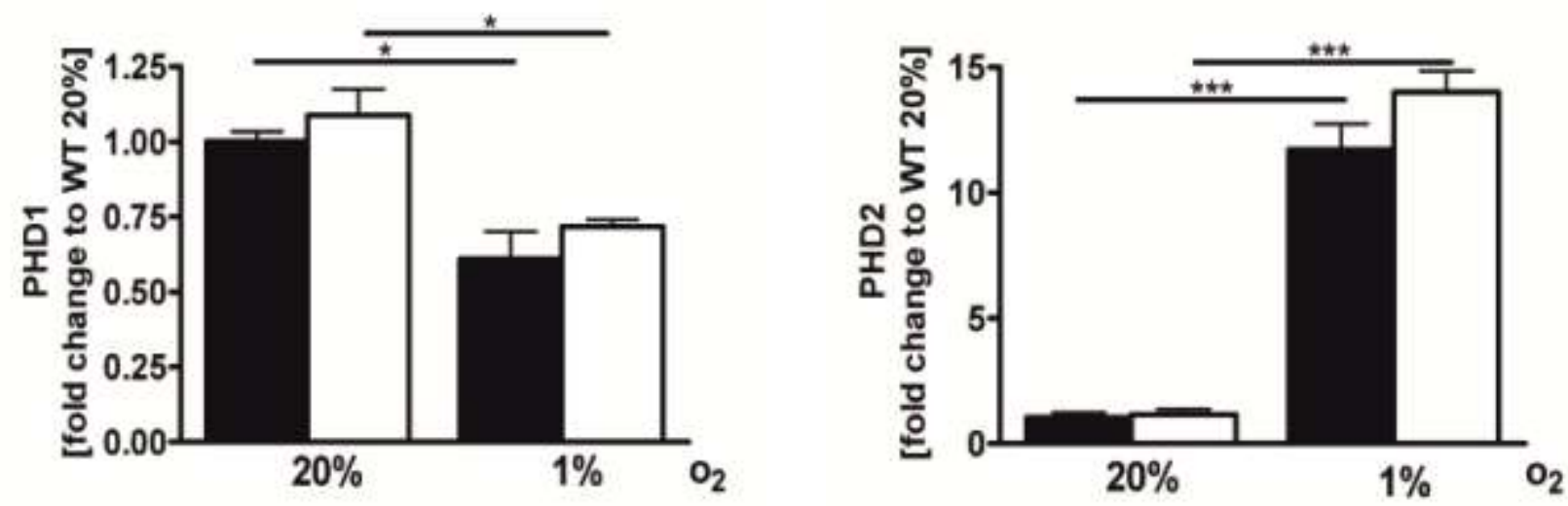

Figure 14: mRNA expression of PHD1 and PHD2 of wt and PHD3 ${ }^{-/}$macrophages

PHD1 and PHD2 RNA levels were quantified by qRT-PCR in wt (black bars) and PHD3 ${ }^{-/}$(white bars) BMDM, which were incubated for $24 \mathrm{hrs}$ in normoxia $\left(20 \% \mathrm{O}_{2}\right)$ or hypoxia $\left(1 \% \mathrm{O}_{2}\right)$. Shown are mean values $\pm \mathrm{SD}, \mathrm{n}=3,{ }^{*} \mathrm{p}<0.05,{ }^{* * *} \mathrm{p}<0.001$.

Western blots were performed to confirm the data obtained by analyzing mRNA expression of PHD2 and PHD3 at the protein level. Wt and PHD3 ${ }^{-/}$BMDM were cultured under $20 \%$ and $1 \% \mathrm{O}_{2}$ conditions for 24 hrs. Expression of PHD3, PHD2 and HIF-1 $\alpha$ was analyzed at protein level both in normoxic and hypoxic conditions (Fig. 15). PHD1 was not analyzed based on the lack of a suitable antibody. In line with the RNA data, at protein level a significant decrease of PHD3 was seen in the PHD3 ${ }^{-/}$BMDM. This difference was more obvious after incubating the cells for $24 \mathrm{hrs}$ at hypoxia compared to normoxia based on the hypoxic induction of PHD3. PHDs regulate the stability of HIF-1 $\alpha$ and HIF-2 $\alpha$. A knockout of PHD2 alone is indeed sufficient to stabilize HIF $\alpha$ in normoxia. Knockout of PHD3 in the BMDM did however not result in a significant change in PHD2, HIF-1 $\alpha$ and HIF-2 $\alpha$ protein levels in normoxia. The hypoxic induction of all 
three proteins was not altered in the $\mathrm{PHD}^{-/}$BMDMs likewise indicating that the reduction of PHD3 expression alone is not sufficient to induce HIF $\alpha$ stabilization.

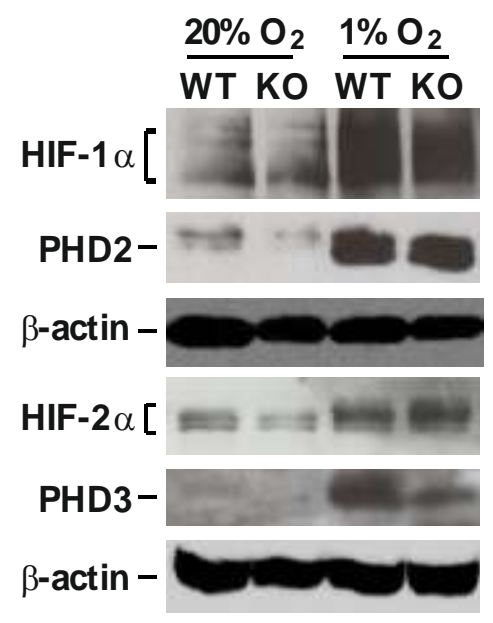

Figure 15: Protein expression of PHD3, PHD2, HIF-1 $\alpha$ and HIF-2 $\alpha$ of wt and PHD3 ${ }^{-1-}$ BMDM

BMDM were isolated from wt or $\mathrm{PHD}^{-1-}(\mathrm{KO})$ mice. Cells were incubated for $24 \mathrm{hrs}$ in normoxia $\left(20 \% \mathrm{O}_{2}\right)$ or hypoxia $\left(1 \% \mathrm{O}_{2}\right)$. Subsequently, cells were lysed and HIF-1 $\alpha$, PHD2, HIF-2a, PHD3 and $\beta$-actin protein levels were analyzed by Western blots.

\subsection{HIF-dependent target gene expression is unchanged in PHD3 $^{-/}$BMDM}

To further confirm that HIF $\alpha$ stabilization and HIF activity were not affected by knocking out PHD3 the mRNA expression of HIF target genes were investigated. To this end, wt and $\mathrm{PHD}^{-{ }^{-}}$BMDM were incubated in normoxia $\left(20 \% \mathrm{O}_{2}\right)$ or hypoxia $\left(1 \% \mathrm{O}_{2}\right)$ for $24 \mathrm{hrs}$ and the mRNA expression levels of the HIF target genes pyruvate kinase M2 (PKM2), phosphofructokinase (Pfk) and pyruvate dehydrogenase kinase-1 (PDK-1) were quantified. The normoxic RNA expression as well as the hypoxic induction of these HIF target genes was unaltered in the PHD3 ${ }^{-/-}$BMDM (Fig. 16). These results indicate that knocking down PHD3 is not sufficient to affect HIF dependent pathways in BMDM. 

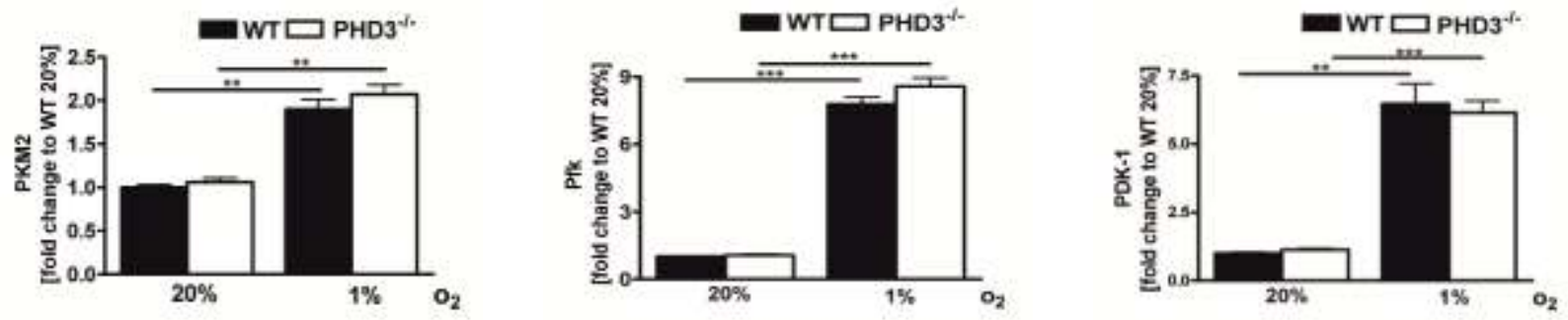

Figure 16: mRNA expression of HIF target genes of wt and $\mathrm{PHD}^{-{ }^{--}} \mathrm{BMDM}^{-}$

The expression of the HIF target genes PKM2, Pfk and PDK-1 on mRNA level was analyzed after cultivating BMDM for 24 hrs at $20 \% \mathrm{O}_{2}$ or $1 \% \mathrm{O}_{2}$ by qRT-PCR. Shown are mean values $\pm \mathrm{SD}, \mathrm{n}=3,{ }^{* *} \mathrm{p}<0.01,{ }^{* * *} \mathrm{p}<0.001$.

To gain insight if there are any other differentially expressed genes in $\mathrm{PHD}^{-/}$versus wt BMDM, an unbiased transcriptome screen was performed in collaboration with the Transkriptions Analyse Labor (TAL, University Medical Center Göttingen). BMDM were incubated in normoxia $\left(20 \% \mathrm{O}_{2}\right)$ or hypoxia (1\% $\mathrm{O}_{2}$ ). In the following unbiased transcriptome screen I could indeed not find any significantly differentially expressed gene comparing wt versus $\mathrm{PHD}^{-/-}$BMDM in normoxia and hypoxia (Fig. 17). There was as expected a whole set of RNAs, which were upregulated in hypoxia in wt and PHD3 ${ }^{-/-}$BMDM. This classical hypoxic response however was not altered by the knockout of PHD3.
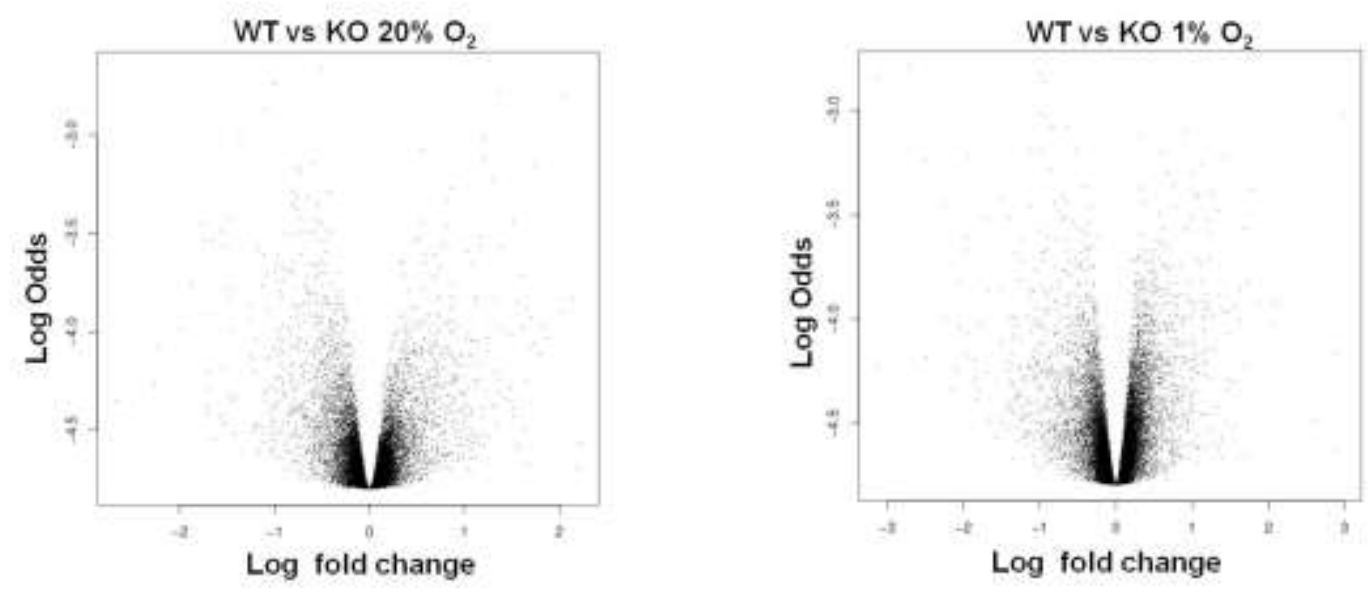

Figure 17: Volcano plot for differentially expressed genes under normoxia and hypoxia

$\mathrm{PHD}^{-/}$and wt BMDM, which were isolated from three independent mice for each genotype, were cultivated for $48 \mathrm{hrs}$ at $20 \% \mathrm{O}_{2}$ or $1 \% \mathrm{O}_{2}$. Subsequently, cells were lysed and RNA isolated. RNA samples were analyzed in a transcriptome microarray assay. The volcano blots were generated based on the microarray results. 
Among the RNAs which were identified to be upregulated in hypoxia there were classical HIF-target genes like Bnip3, Egln3, arginase etc. (Table 3.1). This analysis served as internal quality control for the screen.

\begin{tabular}{|c|c|c|}
\hline Table 3.1 & $\begin{array}{l}\text { List of genes, which were identified to be highly } \\
\text { induced in hypoxia in wt BMDM }\end{array}$ & Fold change \\
\hline Ppp1r3g & protein phosphatase 1, regulatory (inhibitor) subunit 3G & 7.82 \\
\hline Rcor2 & REST corepressor 2 & 5.30 \\
\hline Ankrd37 & ankyrin repeat domain 37 & 5.50 \\
\hline Fam162a & family with sequence similarity 162 , member $A$ & 4.17 \\
\hline Bnip3 & BCL2/adenovirus E1B interacting protein 3 & 4.57 \\
\hline Egln3 & EGL nine homolog 3 (C. elegans) & 6.28 \\
\hline Egln3 & EGL nine homolog 3 (C. elegans) & 6.33 \\
\hline Gipr & gastric inhibitory polypeptide receptor & 7.61 \\
\hline Mboat2 & membrane bound O-acyltransferase domain containing 2 & 5.54 \\
\hline Prelid2 & PRELI domain containing 2 & 4.86 \\
\hline Rgs11 & regulator of G-protein signaling 11 & 4.91 \\
\hline Triobp & TRIO and F-actin binding protein & 5.55 \\
\hline Mgarp & mitochondria localized glutamic acid rich protein & 8.33 \\
\hline Ak4 & adenylate kinase 4 & 6.15 \\
\hline Bnip3 & BCL2/adenovirus E1B interacting protein 3 & 4.31 \\
\hline Gm5486 & predicted gene 5486 & 4.36 \\
\hline Smtnl2 & smoothelin-like 2 & 7.31 \\
\hline Ero1l & ERO1-like (S. cerevisiae) & 4.55 \\
\hline Ppp1r3c & protein phosphatase 1 , regulatory (inhibitor) subunit $3 \mathrm{C}$ & 5.10 \\
\hline Prr15 & proline rich 15 & 5.54 \\
\hline Adm & adrenomedullin & 4.28 \\
\hline Skint3 & selection and upkeep of intraepithelial T cells 3 & 4.49 \\
\hline Slc16a3 & solute carrier family 16 (monocarboxylic acid transporters), member 3 & 4.17 \\
\hline Glt25d2 & glycosyltransferase 25 domain containing 2 & 4.48 \\
\hline Bnip3 & BCL2/adenovirus E1B interacting protein 3 & 4.68 \\
\hline Arg1 & arginase, liver & 8.29 \\
\hline Xpnpep2 & X-prolyl aminopeptidase (aminopeptidase P) 2, membrane-bound & 5.23 \\
\hline Gm3367 & predicted gene 3367 & 6.12 \\
\hline Muc2 & mucin 2 & 6.05 \\
\hline Dapk2 & death-associated protein kinase 2 & 4.55 \\
\hline Plod2 & procollagen lysine, 2-oxoglutarate 5-dioxygenase 2 & 5.25 \\
\hline F13a1 & coagulation factor XIII, A1 subunit & 5.63 \\
\hline Ak4 & adenylate kinase 4 & 4.67 \\
\hline Nos2 & nitric oxide synthase 2 , inducible & 4.02 \\
\hline Nrbp2 & nuclear receptor binding protein 2 & 4.29 \\
\hline 5430405G05Rik & RIKEN cDNA 5430405G05 gene & 4.11 \\
\hline
\end{tabular}




\begin{tabular}{|llr|}
\hline Sh3gl3 & SH3-domain GRB2-like 3 & 4.22 \\
\hline Kbtbd11 & kelch repeat and BTB (POZ) domain containing 11 & 4.21 \\
\hline Apln & apelin & 4.11 \\
\hline Plekha6 & pleckstrin homology domain containing, family A member 6 & 4.34 \\
\hline
\end{tabular}

Additionally, I was able to identify a cluster of small G-protein related factors, which were altered in hypoxia in both genotypes (Table 3.2). The hypoxic regulation of these factors was not described so far. The Rho GTPase activating protein 29 (ArhGAP29) was found to be induced in hypoxia. It is markedly involved in controlling Rho activity and cytoskeletal dynamics in hypoxia. This finding was in the meantime verified in other cell lines by members of the Institute of Cardiovascular Physiology and initiated an independent project on the hypoxic regulation of ArhGAP29 and the implication of this for the regulation of the actin cytoskeleton.

\begin{tabular}{|ll|} 
Table 3.2 & $\begin{array}{c}\text { List of Rho-GTPase associated genes, which were identified to be } \\
\text { differentially expressed in hypoxia }\end{array}$ \\
\hline Arhgap19 & Rho GTPase activating protein 19 \\
\hline Arhgdig & Rho GDP dissociation inhibitor (GDI) gamma \\
\hline Arap2 & ArfGAP with RhoGAP domain, ankyrin repeat and PH domain 2 \\
\hline Srgap3 & SLIT-ROBO Rho GTPase activating protein 3 \\
\hline Arhgap29 & Rho GTPase activating protein 29 \\
\hline Kalrn & kalirin, RhoGEF kinase \\
\hline Arhgap28 & Rho GTPase activating protein 28 \\
\hline Arhgap15 & Rho GTPase activating protein 15 \\
\hline Fgd2 & FYVE, RhoGEF and PH domain containing 2 \\
\hline Arhgap21 & Rho GTPase activating protein 21 \\
\hline Arhgap27 & Rho GTPase activating protein 27 \\
\hline Plekhg6 & pleckstrin homology domain containing, family G (with RhoGef domain) member \\
\hline Arhgef19 & Rho guanine nucleotide exchange factor (GEF) 19 \\
\hline Syde1 & synapse defective 1, Rho GTPase, homolog 1 (C. elegans) \\
\hline
\end{tabular}

It has already been reported that apart from HIF $\alpha$ under specific circumstances PHDs can regulate

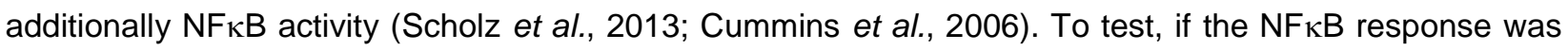
altered as a consequence of the PHD3 knockout, wt and $\mathrm{PHD}^{-/-} \mathrm{BMDMs}$ were cultured under control and starved conditions (no FCS in normoxia) for $24 \mathrm{hrs}$ or stimulated with $100 \mathrm{ng}$ LPS for $12 \mathrm{hrs}$. Subsequently 
cells were lysed and NFKB activity was analyzed. The assay revealed that in the $\mathrm{PHD}^{-/-} \mathrm{BMDM}^{-1}$ there was no obvious difference in NFkB activity compared to the wt cells under resting conditions or after serum starvation (Figure 18). After stimulation with LPS, however, the wt BMDM demonstrated higher NF-kB activity compared to the $\mathrm{PHD}^{-/}$BMDM, which is in line with the above referenced work that has uncovered mechanisms by which hypoxia modulates the activation of NFkB through decreased oxygendependent suppression of the key regulators of this pathway (Scholz et al., 2013; Cummins et al., 2006).

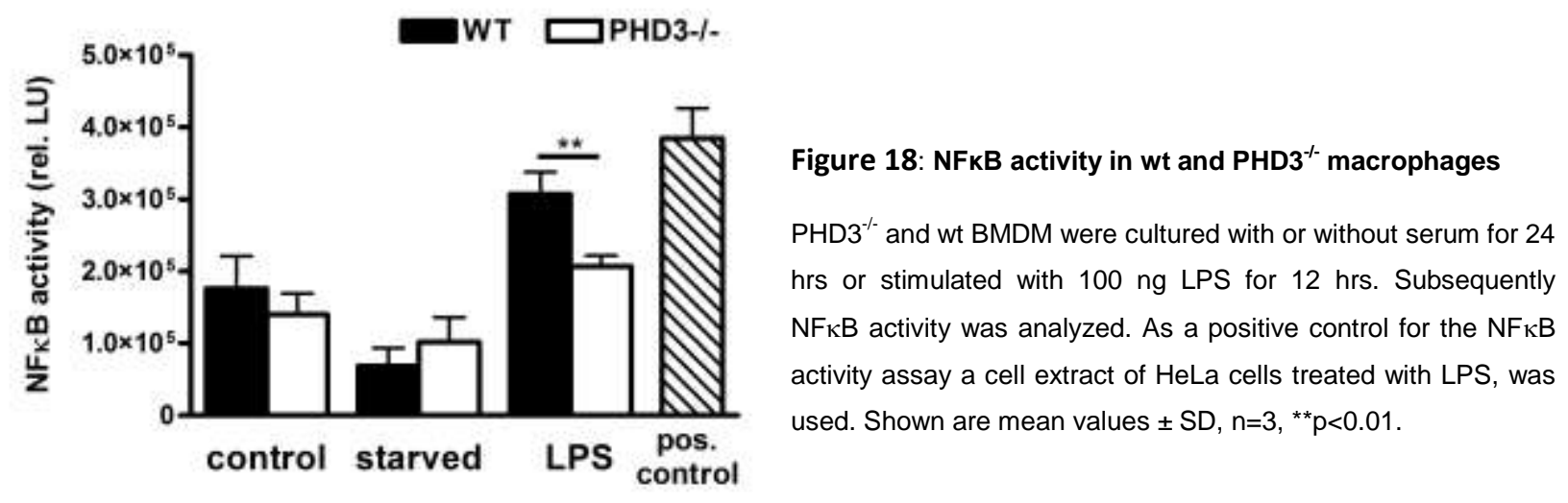

\subsection{Macrophage polarization is unaffected in PHD3 ${ }^{-/-}$BMDM}

Macrophages display remarkable plasticity and can change their phenotype upon stimulation (Mosser and Edwards, 2008). The most prominent macrophage populations are the so called M1 and M2-polarized macrophages. M1-polarized macrophages are pro-inflammatory and tissue destructive, whereas M2polarized macrophages are anti-inflammatory and involved in tissue remodelling as well as angiogenesis. Macrophage polarization can be affected by HIF-1 $\alpha$ and HIF-2 $\alpha$ (Takeda et al., 2010) (Takeda et al). To analyze if PHD3 affects macrophage polarization we treated wt and $\mathrm{PHD}^{-/}$BMDM, which were differentiated for 8 days, with LPS and the $T_{H} 1$ cytokine IFN $\gamma$ or the $T_{H} 2$ cytokine IL-4 to functionally characterize M1 and M2-polarization, respectively (Fig. 19 a and b). Successful M1 and M2-polarization after stimulation was verified by increased RNA levels of the M1 markers IL-6, iNOs and TNF $\alpha$ as well as the M2 markers arginase, Ym-1 and Fizz, respectively. Expression levels of the M1 and M2 marker RNAs were not different comparing wt and $\mathrm{PHD}^{-/-}$BMDM. 
a
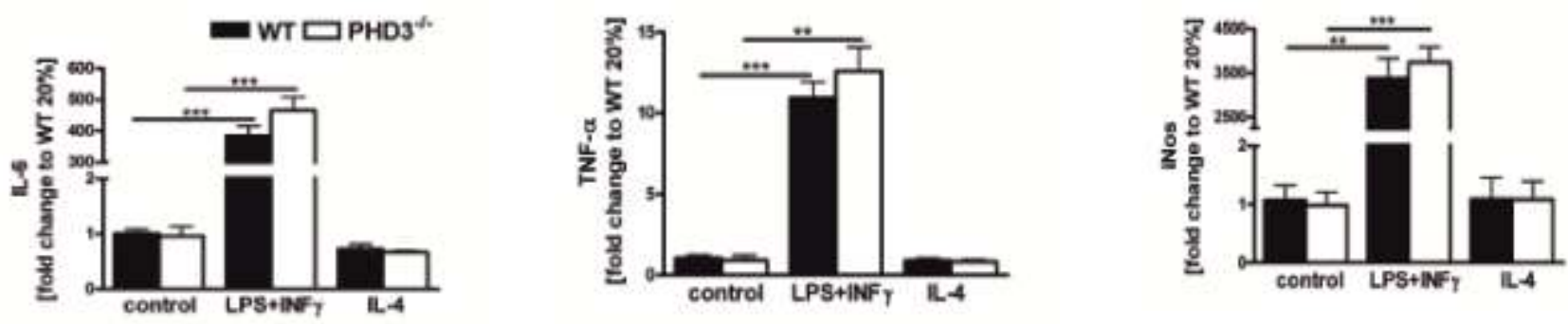

b
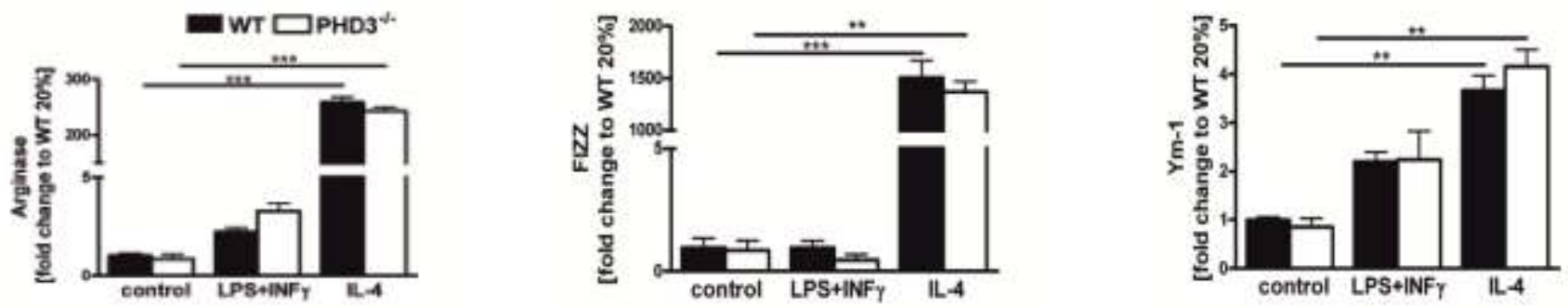

Figure 19: Macrophage polarization of $\mathrm{PHD3}^{-/-}$macrophages

$\mathrm{PHD}^{-/}$and wt BMDM, which were differentiated for 8 days, were stimulated with LPS+INFY (M1-polarization) or IL-4 (M2polarization) for $6 \mathrm{hrs}$, subsequently RNA levels for the (a) M1-polarization markers IL-6, iNos and TNFa (b) the M2-polarization markers Arginase, Ym-1 and FIZZ were quantified by qRT-PCR. Shown are mean values $\pm S D, n=3,{ }^{* *} p<0.01,{ }^{\star * *} p<0.001$.

The above findings were further confirmed at protein level, by investigating the concentrations of IL-6 and TNF $\alpha$ in the cell culture supernatants. Similar to the above described experiments wt and PHD3 ${ }^{-/}$BMDM, which were differentiated for 8 days, were treated with LPS and the $T_{H} 1$ cytokine IFN $\gamma$. Then the culture supernatant was harvested and FACS analyses were performed to investigate the cytokine concentrations. IL-6 and TNF $\alpha$ protein levels were significantly induced in the cell culture supernatants after stimulation with LPS+IFN $\gamma$ (Fig. 20). In line with the RNA data, the concentrations of IL-6 and TNF $\alpha$ were not different comparing wt and $\mathrm{PHD}^{-/-}$BMDM. 

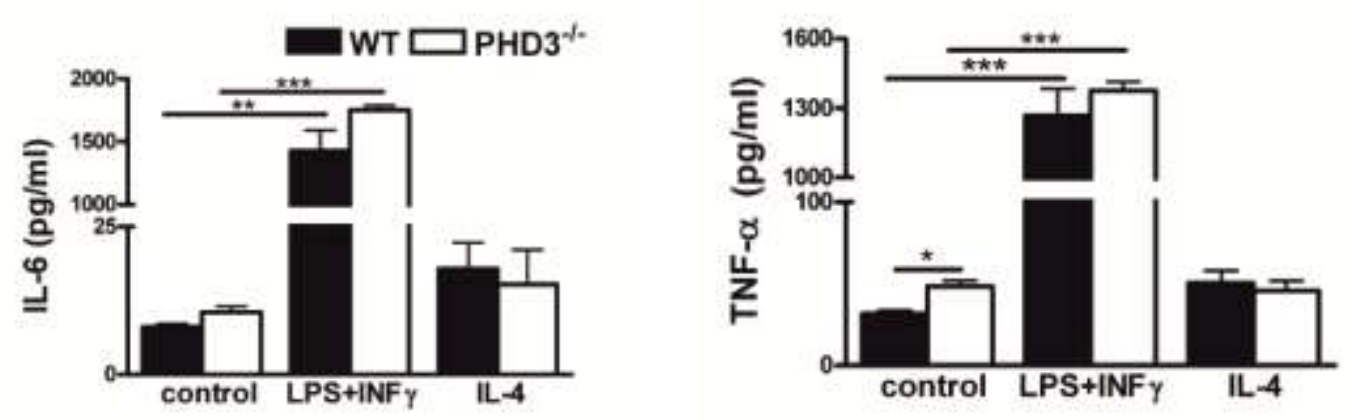

Figure 20: IL-6 and TNFa secretion of $\mathrm{PHD}^{-/-}$macrophages

$\mathrm{PHD3}^{-/}$and wt BMDM were stimulated with LPS+INFY (M1-polarization) or IL-4 (M2-polarization) for 6 hrs, subsequently protein levels for the M1-polarization markers IL-6 and TNF $\alpha$ were quantified by FACS analysis. Shown are mean values \pm SD, $n=3$, ${ }^{* *} \mathrm{p}<0.01,{ }^{* * *} \mathrm{p}<0.001$.

\subsection{PHD3 $^{-/-}$BMDM are protected from apoptotic cell death}

PHD3 has been associated with cell survival decisions in the context of apoptosis in various cell and animal models (Bishop et al., 2008) (Wottawa et al., 2010) (Jaakkola and Rantanen, 2013). Therefore, we next determined the role of PHD3 in macrophage cell-survival pathways. To analyze, if apoptosis is altered in the $\mathrm{PHD}^{-/}$BMDM I deprived cells for $48 \mathrm{hrs}$ from serum (Fig. 21). Starving the cells induced apoptosis in wt BMDM as determined by quantifying TUNEL positive cells which marks the fragmented DNA/damaged DNA in the cell. Most interestingly in $\mathrm{PHD}^{-/-}$BMDM, apoptosis was just slightly induced under starvation compared to wt cells. Thus, the $\mathrm{PHD}^{-/-}$macrophages were significantly protected under stress condition when compared to the respective wt macrophages. 


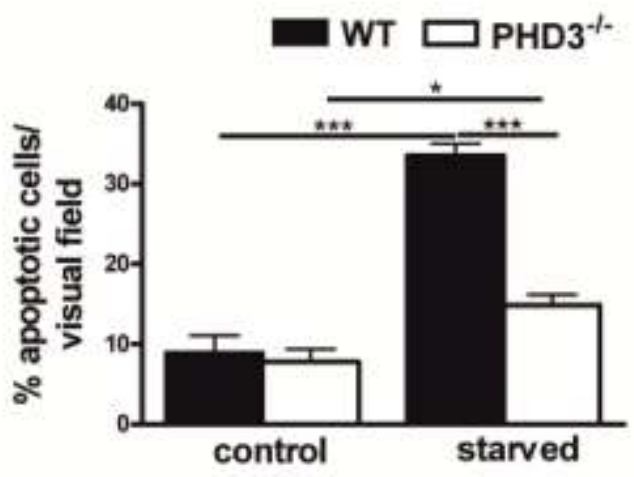

Figure 21: TUNEL assay comparing wt and $\mathrm{PHD}^{-/-} \mathrm{BMDM}^{-1}$ apoptosis

$\mathrm{PHD3}^{-/}$and wt BMDM were cultivated with or without serum (starved) for $48 \mathrm{hrs}$, subsequently the number of apoptotic cells was quantified by TUNEL assay. A knockout of PHD3 in macrophages significantly protects the cells from apoptosis when serum starved. Shown are mean values $\pm S D, n=3,{ }^{*} p<0.05,{ }^{* * *} p<0.001$.

The above obtained result was further confirmed by Annexin $V$ assays. With this assay the membrane integrity of the cells is analyzed to investigate the amount of apoptotic cells. Both wt and $\mathrm{PHD}^{-/-} \mathrm{BMDM}^{-}$ were cultured for $48 \mathrm{hrs}$ in control or starved conditions. Afterwards the cells were stained with an antiAnnexin $V$ antibody and were analyzed using FACS. In line with the TUNEL assay, the Annexin V assay showed that starving the cells induced apoptosis in wt BMDM whereas $\mathrm{PHD3}^{-/}$macrophages were significantly protected. (Fig. 22)

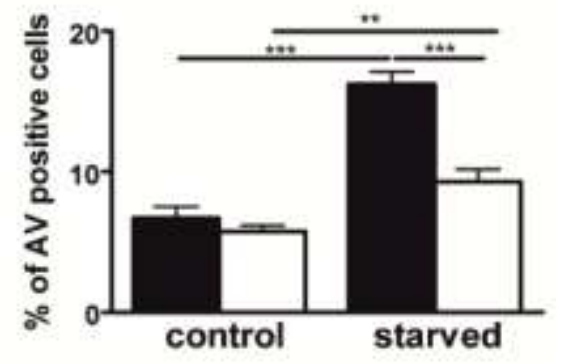

\section{Figure 22: Annexin V staining of wt and $\mathrm{PHD}^{-/-}$BMDM}

$\mathrm{PHD3}^{-/}$and wt BMDM were cultivated with or without serum (starved) for $48 \mathrm{hrs}$, subsequently the number of Annexin $\mathrm{V}$ positive cells were quantified. $\mathrm{PHD}^{-/}$in macrophages significantly protects the cells from apoptosis when serum starved. Shown are mean values $\pm S D, n=6,{ }^{* *} p<0.01,{ }^{* * *} p<0.001$.

The partial protection of $\mathrm{PHD}^{-/}$BMDM after serum starvation was further confirmed by performing Calcein-AM assays to see if the anti-apoptotic effect is reflected in altered viability of the cells. Indeed, $\mathrm{PHD3}^{-/-}$BMDM had a higher viability under control conditions and after 48 hrs of starvation compared to wt cells (Fig. 23). 


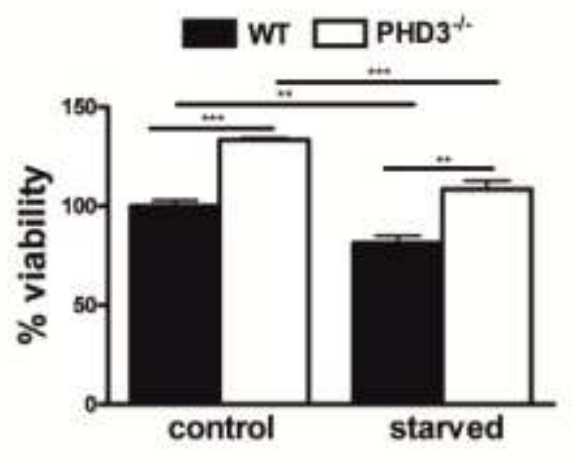

Figure 23: Viability assay wt and $\mathrm{PHD}^{-/-} \mathrm{BMDM}$

$\mathrm{PHD3}^{-/}$and wt BMDM were cultivated with or without serum (starved) for 48 hrs and then the cell viability was determined using the Calcein-AM viability assay. $\mathrm{PHD}^{-/} \mathrm{BMDM}^{-1}$ showed significantly increased viability both in control and starved conditions. $n=6$, mean $\pm S D,{ }^{* *} p<0.01,{ }^{* * *} p<0.001$.

To analyze if the PHD3 mediated anti-apoptotic effect is just limited to serum deprivation, macrophages were cultured in the presence of the known pro-apoptotic agents S-nitroso-N-acetylpenicillamine (SNAP, $100 \mu \mathrm{M}$ ), staurosporine (stauro, $500 \mathrm{nM}$ ) or LPS (5 or $10 \mu \mathrm{g} / \mathrm{mL}$ ) and rates of apoptosis were determined (Fig. 24). The result obtained showed that in the presence of the pro-apoptotic agents tested PHD3 ${ }^{-/}$ macrophages were significantly protected as compared to the respective wt BMDM.

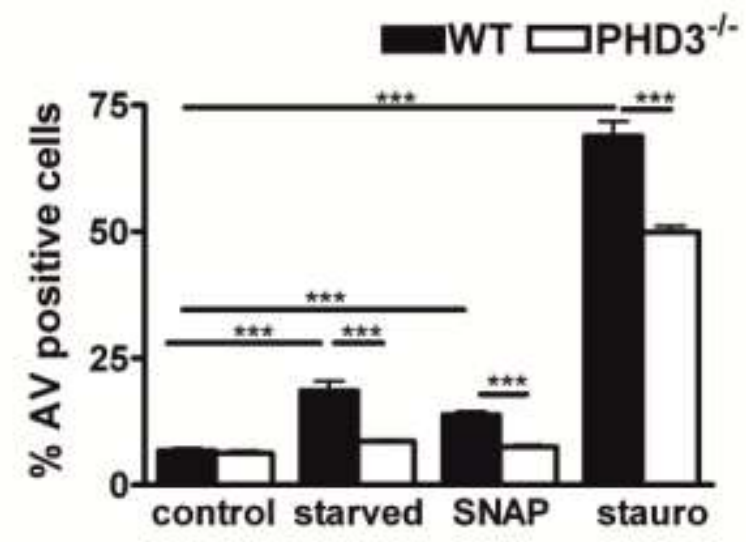

Figure 24: Annexin V assay staining of wt and $\mathrm{PHD3}^{-/}$BMDM with apoptotic inducers treatment

The number of Annexin V-positive cells were quantified after cultivating PHD3 ${ }^{-/}$and wt BMDM with or without (starved) serum for 48 hrs or treating the cells with $100 \mu \mathrm{M}$ SNAP, $500 \mathrm{nM}$ stauro or $5-10 \mu \mathrm{g} / \mathrm{mL}$ LPS for $12 \mathrm{hrs} . \mathrm{n}=5$, mean $\pm \mathrm{SD},{ }^{* * *} \mathrm{p}<0.001$.

In addition to the treatment with pro-apoptotic agents in normoxia the PHD3-mediated phenotype was also confirmed under hypoxic conditions. To analyze the impact of hypoxia on serum starvation induced apoptosis I exposed wt and $\mathrm{PHD3}^{-/}$BMDM to normoxia $\left(20 \% \mathrm{O}_{2}\right)$ or hypoxia $\left(1 \% \mathrm{O}_{2}\right)$ during serum 
starvation. Both wt and $\mathrm{PHD}^{-/}$BMDM were cultured for $48 \mathrm{hrs}$ in control or starved conditions at $20 \% \mathrm{O}_{2}$ and $1 \% \mathrm{O}_{2}$ (Fig. 25). Then TUNEL assays were performed and the cells were analyzed to determine the

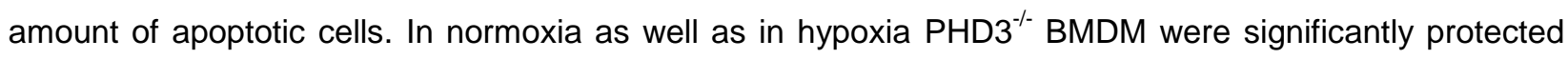
from apoptosis compared to wt macrophages. In hypoxia however, the protective effect was slightly but not significantly weakened in the $\mathrm{PHD}^{-/}$BMDM. This correlates to the hypoxic induction of PHD3 as demonstrated above, which was present albeit less significantly in the PHD3 ${ }^{-/-}$macrophages.

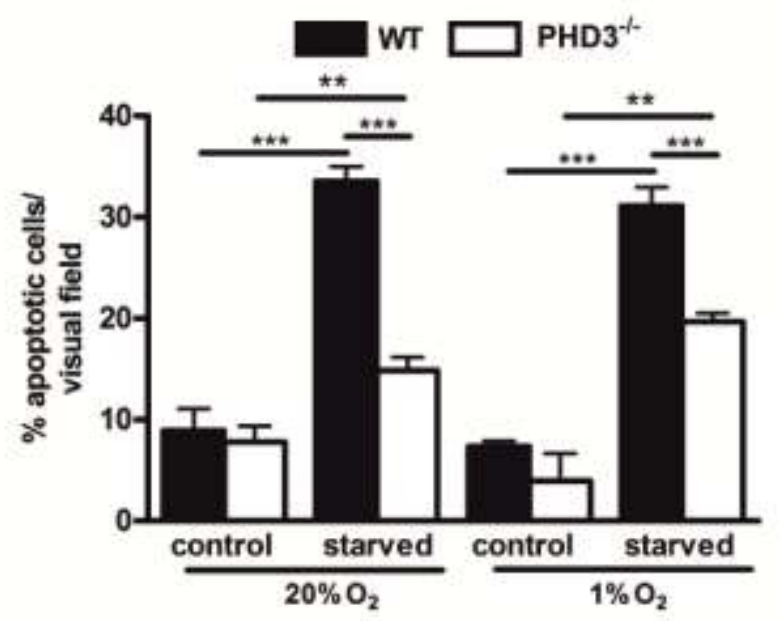

Figure 25: TUNEL assay of wt and PHD3 ${ }^{-/-}$BMDM comparing normoxic versus hypoxic effects

TUNEL-positive cells were quantified after cultivating $\mathrm{PHD}^{-/-}$and wt BMDM with or without serum (starved) for $48 \mathrm{hrs}$ at $20 \% \mathrm{O}_{2}$ or $1 \% \mathrm{O}_{2} . \mathrm{n}=3$, mean $\pm \mathrm{SD},{ }^{* *} \mathrm{p}<0.01,{ }^{* *} \mathrm{p}<0.001$.

To gain insight into the apoptotic phenotype an unbiased transcriptome analysis was performed. Using a mouse genome array we compared RNA transcript abundance in wt and PHD3 ${ }^{-/}$BMDM, which were deprived of serum for $48 \mathrm{hrs}$. Among the transcript changes, which differed in their extent in response to the serum deprivation between wt and $\mathrm{PHD}^{-/}$BMDM, I identified in total 26 transcripts that were upregulated (Table 3.3) and 19 transcripts that were down-regulated in response to serum starvation (Table 3.4). 
Table 3.3: Genes of the RNAs, which were identified to be induced and differentially expressed comparing wt and $\mathrm{PHD}^{-/-}$BMDM after serum starvation

\begin{tabular}{|rll|}
\hline Gene ID & Symbol & Description \\
\hline $\mathbf{5 6 4 7 3}$ & Fads2 & fatty acid desaturase 2 \\
\hline $\mathbf{1 7 3 9 2}$ & Mmp3 & matrix metallopeptidase 3 \\
\hline $\mathbf{1 4 9 9 0}$ & H2-M2 & histocompatibility 2, M region locus 2 \\
\hline $\mathbf{2 6 3 6 0}$ & Angpt12 & angiopoietin-like 2 \\
\hline $\mathbf{7 6 0 0 9}$ & $5830415 G 21$ Rik & RIKEN cDNA 5830415G21 gene \\
\hline $\mathbf{1 4 8 5 8}$ & Gsta2 & glutathione S-transferase, alpha 2 (Yc2) \\
\hline $\mathbf{2 4 6 0 4 9}$ & Slc36a2 & $\begin{array}{l}\text { solute carrier family 36 (proton/amino acid symporter) } \\
\text { member 2 }\end{array}$ \\
\hline $\mathbf{1 4 2 3 8}$ & Foxf2 & forkhead box F2 \\
\hline $\mathbf{6 8 0 2 7}$ & Tmem178 & transmembrane protein 178 \\
\hline $\mathbf{1 8 5 4 8}$ & Pcsk1 & proprotein convertase subtilisin/kexin type 1 \\
\hline $\mathbf{1 7 3 8 4}$ & Mmp10 & matrix metallopeptidase 10 \\
\hline $\mathbf{2 0 4 0 8}$ & Sh3gl3 & SH3-domain GRB2-like 3 \\
\hline $\mathbf{1 9 7 4 6}$ & Rhd & Rh blood group, D antigen \\
\hline $\mathbf{1 3 0 5 1}$ & Cx3cr1 & chemokine (C-X3-C) receptor 1 \\
\hline $\mathbf{1 9 1 2 4}$ & Procr & protein C receptor, endothelial \\
\hline $\mathbf{1 5 4 9 0}$ & Hsd17b7 & hydroxysteroid (17-beta) dehydrogenase 7 \\
\hline $\mathbf{2 0 7 6 8 3}$ & Igsf11 & immunoglobulin superfamily, member 11 \\
\hline $\mathbf{1 6 1 9 7}$ & Il7r & interleukin 7 receptor \\
\hline $\mathbf{7 9 2 0 1}$ & Tnfrsf23 & tumor necrosis factor receptor superfamily, member 23 \\
\hline $\mathbf{5 6 0 1 8}$ & Stard10 & START domain containing 10 \\
\hline $\mathbf{2 2 8 5 4 3}$ & Rhov & ras homolog gene family, member V \\
\hline $\mathbf{2 1 7 2 6 5}$ & Abca5 & ATP-binding cassette, sub-family A (ABC1), member 5 \\
\hline $\mathbf{1 2 6 1 4}$ & Celsr1 & $\begin{array}{l}\text { cadherin, EGF LAG seven-pass G-type receptor 1 (flamingo } \\
\text { homolog, Drosophila) }\end{array}$ \\
\hline $\mathbf{6 2 7 2 7 0}$ & Gm10055 & predicted gene 10055 \\
\hline $\mathbf{3 2 0 1 2 1}$ & 6720473M08Rik & RIKEN cDNA 6720473M08 gene \\
\hline $\mathbf{1 9 4 1 2 6}$ & Mtmr11 & myotubularin related protein 11 \\
\hline
\end{tabular}


Table 3.4: Genes of the RNAs, which were identified to be reduced and differentially expressed comparing wt and $\mathrm{PHD}^{-/-} \mathrm{BMDM}$ after serum starvation

\begin{tabular}{|c|c|c|}
\hline Gene ID & Symbol & Description \\
\hline 20511 & Slc1a2 & $\begin{array}{l}\text { solute carrier family } 1 \text { (glial high affinity glutamate transporter), } \\
\text { member } 2\end{array}$ \\
\hline 69590 & Gpx8 & glutathione peroxidase 8 (putative) \\
\hline 12035 & Bcat1 & branched chain aminotransferase 1 , cytosolic \\
\hline 17472 & Gbp4 & guanylate binding protein 4 \\
\hline 64074 & Smoc2 & SPARC related modular calcium binding 2 \\
\hline 20350 & Sema3f & $\begin{array}{l}\text { sema domain, immunoglobulin domain (lg), short basic domain, } \\
\text { secreted, (semaphorin) 3F }\end{array}$ \\
\hline 109264 & Me3 & malic enzyme 3, NADP(+)-dependent, mitochondrial \\
\hline 241230 & St8sia6 & ST8 alpha-N-acetyl-neuraminide alpha-2,8-sialyltransferase 6 \\
\hline 105785 & Kdelr3 & $\begin{array}{l}\text { KDEL (Lys-Asp-Glu-Leu) endoplasmic reticulum protein retention } \\
\text { receptor } 3\end{array}$ \\
\hline 16429 & Itln1 & intelectin 1 (galactofuranose binding) \\
\hline 12478 & Cd19 & CD19 antigen \\
\hline 12837 & Col8a1 & collagen, type VIII, alpha 1 \\
\hline 69675 & Pxdn & peroxidasin homolog (Drosophila) \\
\hline 20692 & Sparc & secreted acidic cysteine rich glycoprotein \\
\hline 20204 & Prrx2 & paired related homeobox 2 \\
\hline 12831 & Col5a1 & collagen, type V, alpha 1 \\
\hline 22402 & Wisp1 & WNT1 inducible signaling pathway protein 1 \\
\hline 98932 & Myl9 & myosin, light polypeptide 9 , regulatory \\
\hline 18054 & Ngp & neutrophilic granule protein \\
\hline
\end{tabular}

\subsection{Confirming the differential expression of genes by qRTPCR}

The transcriptome screen revealed 45 genes to be differentially expressed in starved $\mathrm{PHD}^{-{ }^{-}}$compared to wt BMDM. To further check the quality of the screen, qRT PCR analyses of some of the identified genes were done (Fig. 26). The RNA of the proprotein convertase subtilisin/kexin type 1 (Pcsk1) and the protein C receptor (Procr) were found to be induced by serum starvation. This was verified by the independent qRT-PCR analyses. Additionally, the differential induction of Pcsk1 and Procr comparing wt and PHD3 ${ }^{-/-}$ BMDMs was verified. Whereas the induction of Pcsk1 after serum starvation was significantly higher in the wt BMDMs compared to the PHD3 ${ }^{-/}$BMDMs, the opposite was found for Prcor. The differential expression 
of WNT1 inducible signaling pathway protein (WISP1) and paired related homeobox 2 (Prrx2), which were both reduced after serum starvation, was verified likewise.
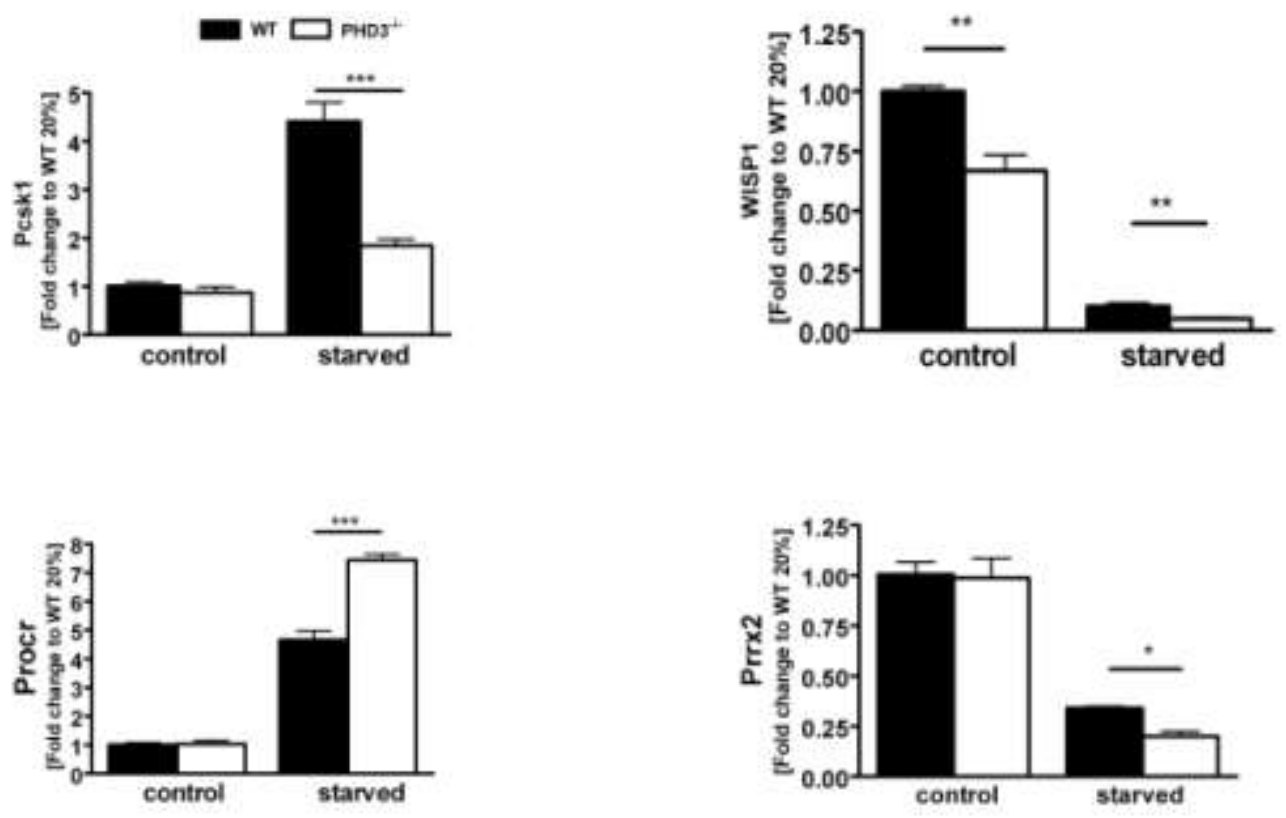

Figure 26: qRT-PCR analysis confirming the differential expression of candidate genes

$\mathrm{PHD}^{-/}$and wt BMDM were cultivated with or without serum for $48 \mathrm{hrs}$ (starved). Subsequently genes from the transcriptome screen Pcsk1, WISP1, Procr and Prrx2 mRNA were analyzed by qRT-PCR. $n=6$, mean $\pm S D,{ }^{*} p<0.05,{ }^{* * *} p<0.001$.

\subsection{Angptl2 is differentially expressed and involved in the differential apoptotic response}

Pro- and anti-apoptotic pathways can be induced by secreted factors. To test, if secreted factors are involved in the differential induction of apoptosis of wt and $\mathrm{PHD}^{-/-}$BMDMs, I performed experiments with wt or $\mathrm{PHD}^{-/}$conditioned medium. Treating wt and $\mathrm{PHD}^{-{ }^{-}}$BMDM during serum deprivation with conditioned medium of serum-deprived $\mathrm{PHD}^{-/}$and wt cells, respectively, revealed a loss of the antiapoptotic phenotype in the PHD3 ${ }^{-/}$BMDM (Fig. 27). This indicated that at least in part a secreted factor is involved in the PHD3-mediated response towards an apoptotic stimulus. 


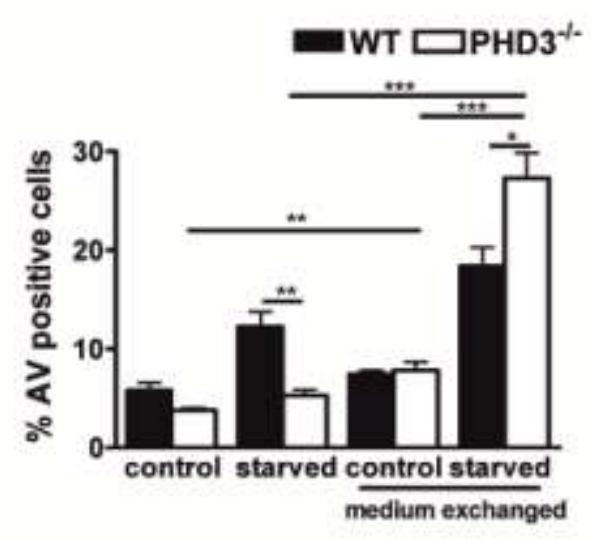

Figure 27: wt conditioned medium induces apoptosis of $\mathrm{PHD}^{-/}$macrophages

$\mathrm{PHD3}^{-/}$and wt BMDM were cultivated with or without serum in total for $48 \mathrm{hrs}$. After $24 \mathrm{hrs}$ the medium was exchanged across the genotypes and cultured for 24 additional hrs. Induction of apoptosis was compared using Annexin $\mathrm{V}$ staining and FACS analysis. $\mathrm{n}=$ 5 mean $\pm S D,{ }^{* *} p<0.01,{ }^{* *} p<0.001$.

The result shown in Fig. 27 made me to go back to the transcriptome screen and look specifically for soluble/secreted factors. Further gene cluster analysis of the 45 genes identified in the above described transcriptome array revealed a cluster of genes (i.e. Angptl2, Col8A1, Col5A1, KDELR3, MYL9 and PXDN), which are known to be co-regulated. Angiopoietin-like proteins (Angptls) are secreted proteins, which like angiopoietin itself have an $\mathrm{N}$-terminal coiled-coil domain and a $\mathrm{C}$-terminal fibrinogen-like domain. So far 7 Angptls have been identified. None of these bind to the angiopoietin receptor Tie2 or to the homologous Tie1 receptor. Angptl2 has been found to affect vascular cells and monocytes. In line Angptl2 functions as a chronic inflammatory mediator in obesity (Tabata et al., 2009), atherosclerotic disease (Tabata et al., 2009), rheumatoid arthritis (Tabata et al., 2009) (Okada et al., 2010), and cancer (Endo et al., 2012). Although the receptor signaling of Angptl2 is not fully understood, some of these biological effects seem to be at least in part mediated via binding to $\alpha 5 \beta 1$ integrin and the paired immunoglobin-like receptor B (PirB) or human orthologue immunoglobin-like receptor B2 (LILERB2) (Tabata et al., 2009). The differential expression of Angptl2 in wt and PHD3 ${ }^{-/}$BMDM after serum starvation was verified by independent qRT-PCR (Fig. 28). To analyze, if hypoxia affects the expression of Angptl2, I additionally exposed the wt and $\mathrm{PHD}^{-/-}$BMDM during serum starvation to $20 \% \mathrm{O}_{2}$ or $1 \% \mathrm{O}_{2}$. Exposure of the macrophages to hypoxia during starvation significantly increased the expression of Angptl2 in the wt but not in the $\mathrm{PHD3}^{-/}$BMDM. 


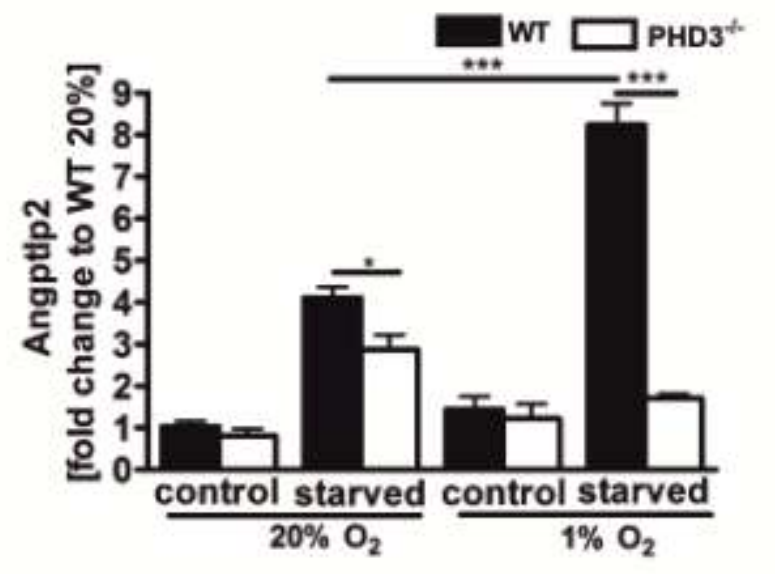

Figure 28: Angptl2 expression of wt and $\mathrm{PHD}^{-/-}$ macrophages

$\mathrm{PHD}^{-/}$and wt BMDM were cultivated with or without (starved) serum for 48 hrs in normoxia $\left(20 \% \mathrm{O}_{2}\right)$ or hypoxia $\left(\begin{array}{lll}1 \% & \mathrm{O}_{2}\end{array}\right)$. Subsequently Angiopoietin-like protein 2 (Angptl2) mRNA was analyzed by $q R T-P C R . n=6$, mean $\pm S D,{ }^{*} p<0.05,{ }^{* * *} p<0.001$.

In the above described experiments I was able to show that the protection from apoptosis in the PHD3 ${ }^{-1-}$ BMDM is not just restricted to the induction of apoptosis after serum starvation. SNAP and stauro treatment resulted in an altered induction of apoptosis in the PHD3 ${ }^{-/}$BMDM likewise. Therefore, Angpt/2 RNA levels were quantified in wt and $\mathrm{PHD}^{-/}$BMDM after treatment with SNAP or stauro to proof that the altered Angpt12 response of the $\mathrm{PHD}^{-/-}$BMDM does occur after treatment with several different apoptotic stimuli. Serum starvation was included in this experiment as positive control. Like in starvation, the Angptl2 RNA levels were less in the PHD3 ${ }^{-/}$BMDM compared to wt cells after SNAP and stauro treatment (Fig. 29).

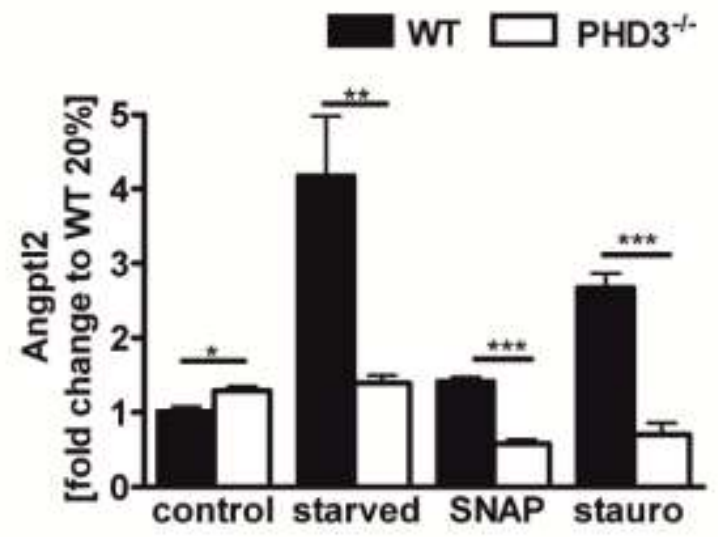

Figure 29: Angptl2 expression under the treatment of apoptotic inducers

$\mathrm{PHD3}^{-/}$and wt BMDM were cultivated with or without serum (starved) or treated with $100 \mu \mathrm{M}$ S-nitroso-N-acetylpenicillamine (SNAP) or $500 \mathrm{nM}$ staurosporine (stauro). Subsequently Angiopoietin-like protein 2 (Angptl2) mRNA was analyzed. $n=6$, mean $\pm S D,{ }^{*} p<0.05,{ }^{* *} p<0.01,{ }^{* *} p<0.001$. Serum starvation was included in the experiment as positive control. 
The differential expression of Angptl2 in wt and $\mathrm{PHD}^{-/}$BMDM was verified at protein level using an ELISA. For this wt and $\mathrm{PHD}^{-/}$BMDM were cultured for $48 \mathrm{hrs}$ both in control and starved conditions. The supernatants were harvested to estimate the Angptl2 concentration in these samples. In line with the mRNA data the Angptl2 protein concentration was less in $\mathrm{PHD}^{-/-}$BMDM cell culture supernatants compared to wt (Fig. 30).

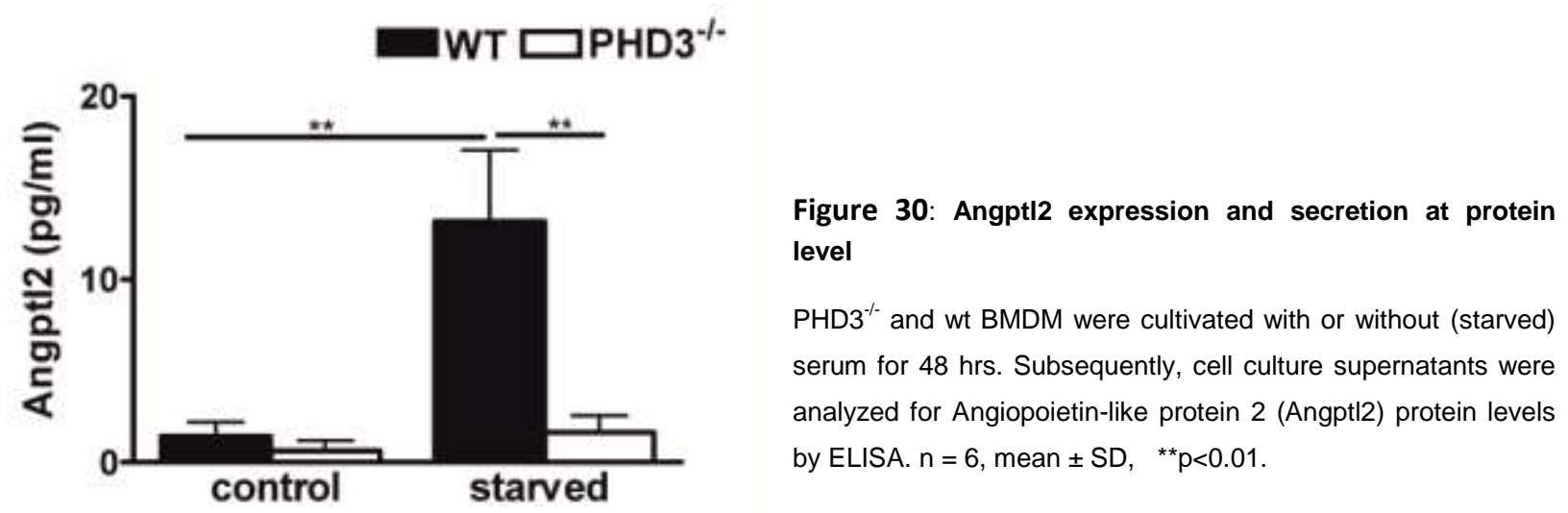

The function of Angptl2 in macrophages is not fully described so far. Moreover, there were at the time no data available, if Angptl2 can affect apoptosis of macrophages. Therefore I analyzed in cooperation with Prof. Y. Oike (Department of Molecular Genetics, Kumamoto University, Japan) the induction of serum starvation-induced apoptosis in wt and Angptl2 knockout (Angpt12 ${ }^{-1}$ ) BMDM. The group of Prof. Y. Oike was able to produce Angptl2 ${ }^{-/}$mice in the past (Tabata, Kadomatsu et al. 2009). These animals were used for the analyses. In line with the anti-apoptotic effect and diminished expression of Angptl2 in the $\mathrm{PHD}^{-/}$cells, BMDM, which were isolated and differentiated from previously described Angptl2 ${ }^{-/}$mice, exhibited less AV-positive cells after serum starvation or stauro treatment (Fig. 31).

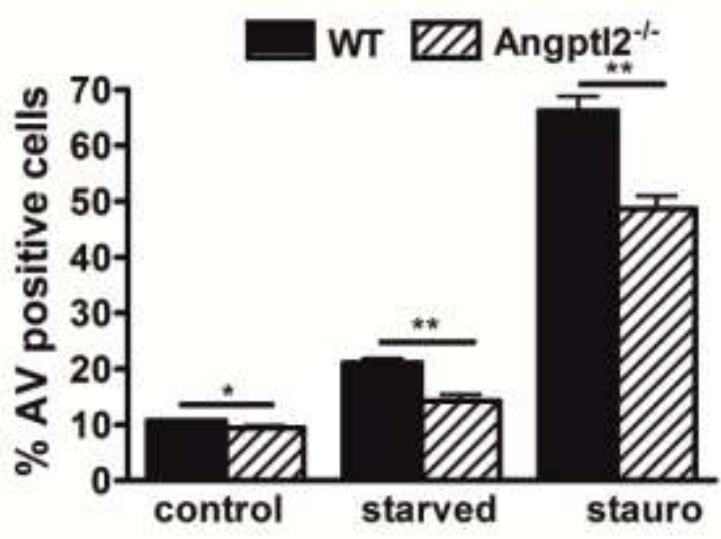

Figure 31: Effect of recombinant Angptl2 on wt BMDM

Angptl2 $2^{-/}$and wt BMDM were cultivated with or without serum (starved) for $48 \mathrm{hrs}$ or exposed to $500 \mathrm{nM}$ staurosporine (stauro) for 12 hrs. Subsequently, induction of apoptosis was compared by Annexin $V$ staining and FACS analysis. $n=4-5$, mean $\pm S D$, ${ }^{*} p<0.05,{ }^{* *} p<0.01$. 


\subsection{Treatment of BMDM with recombinant Angpt12}

In the final experiments I tested, if reconstitution of the diminished Angptl2 response in the PHD3 deficient macrophages would rescue the apoptosis phenotype (Fig. 32). Therefore 2 or $4 \mu \mathrm{g}$ recombinant Angptl2 was added to wt or $\mathrm{PHD}^{-/-}$BMDM during serum starvation. 48 hrs later, the number of Annexin V-positive cells was analyzed. Adding the recombinant Angptl2 to the $\mathrm{PHD3}^{-/-}$BMDM indeed reversed the antiapoptotic effect demonstrating that Angptl2 is at least partially involved in the PHD3-mediated response towards an apoptotic stimulus. Most interestingly, wt BMDM did not respond with increased apoptosis after adding $2 \mu \mathrm{g}$ recombinant Angptl2 under resting conditions or after starvation. After adding $4 \mu \mathrm{g}$ recombinant Angpt12 there was even an anti-apoptotic effect after starvation These data indicate that not only the production of Angptl2 is altered in $\mathrm{PHD}^{-/-}$BMDM but also the cellular response to it.

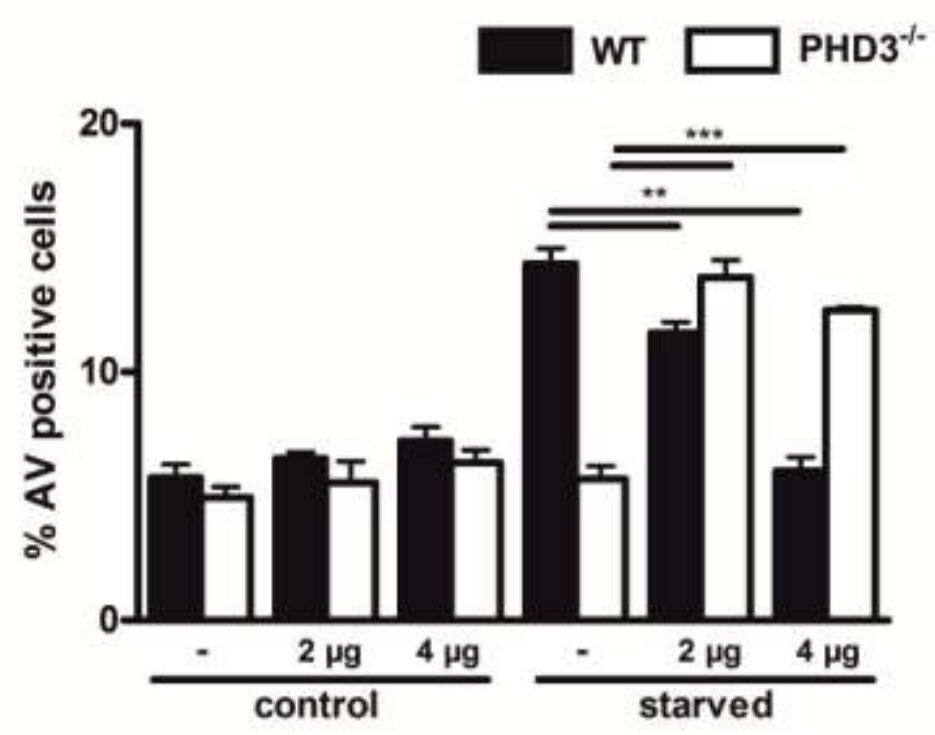

Figure 32: Treatment of wt and $\mathrm{PHD3}^{-/}$BMDM with recombinant Angptl2

$\mathrm{PHD3}^{-/}$and wt BMDM were cultivated with or without serum (starved) in total for $48 \mathrm{hrs}$. Recombinant Angiopoietin-like protein 2 (Angptl2) was added as indicated. Induction of apoptosis was analyzed by Annexin V staining and FACS analysis. $n=5$, mean \pm SD, ${ }^{* *} \mathrm{p}<0.01,{ }^{* * *} \mathrm{p}<0.001$.

As described above, $\alpha 5 \beta 1$ and PirB were previously identified to bind to Angpt|2. This does not include that this orphan ligand does not signal via other receptors. Since the results with the recombinant Angptl2 indicate that the response towards it might be altered in the PHD3 ${ }^{-/}$BMDM, I analyzed the cell surface 
expression of $\alpha 5 \beta 1$ and PirB in wt versus $\mathrm{PHD}^{-/-}$BMDM (Fig. 33). Both receptors could be identified by FACS analysis. The receptor expression levels, however, were not different comparing the BMDM of both genotypes.
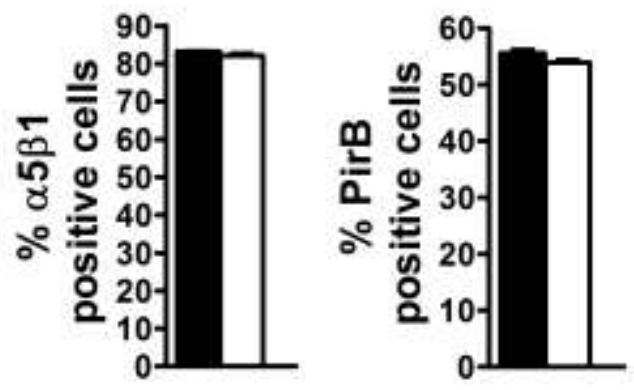

Figure 33: Expression of Angptl2 receptors in wt and PHD3 $^{-/}$ macrophages

$\alpha 5 \beta 1$ and PirB receptor expression was analyzed in $\mathrm{PHD}^{-/}$(white bars) and wt (black bars) BMDM by FACS analysis. $n=5$, mean \pm SD 


\section{Discussion}

Adequate supply of oxygen is an essential prerequisite for living organisms. Insufficient oxygen availability is known as hypoxia. The oxygen sensors PHD 1-3 sense hypoxia and respond to it by regulating the master transcription factor HIF by prolyl hydroxylation at specific prolyl residues, marking the HIFa subunit for proteasomal degradation. HIF-1 $\alpha$ is predominantly hydroxylated by PHD2 and HIF-2 $\alpha$ by PHD3. Although the PHD shares many similarities, they differ in enzymatic activity, expression pattern and specific function. Among the three PHD isoforms, the constitutively expressed PHD2 is the main regulator of HIFa stability in normoxia. In contrast PHD3, which is induced under hypoxia, creates a feedback loop to further regulate HIFa under hypoxia and upon reoxygenation. To gain further insight into the specific function of different PHD isoforms is important for the ongoing development of small molecule PHD inhibitors that are currently tested in preclinical and clinical trials for the treatment of anemia and for cytoprotection. Interfering with any of these PHD isoforms might alter the response of the immune system. It has been shown earlier that, tissue inflammation can lead to hypoxia, resulting in stabilization of HIF-1a or HIF-2 $\alpha$ in the inflamed tissues. Therefore, the interplay and the close connection between PHDs and immunomodulators have to be studied in more detail. Additionally, hypoxia and HIFs are known to be crucial modulators of systemic inflammation (Imtiyaz et al., 2010; Zinkernagel et al., 2007). PHDs are also known to be expressed in leukocytes and macrophages (Peyssonnaux et al., 2005). Myeloid-derived cells are rapidly mobilized to hypoxic areas of ischemic tissues and are acknowledged to contribute to postischemic regeneration. They adapt rapidly through the activation of the HIF signaling pathway. Targeting the PHD/HIF-pathway in the myeloid cell lineage would therefore be a promising strategy to investigate the isoform and cell specific function of PHDs. In the past few years the importance of myeloid cells for angiogenesis and neovascularization in hypoxia-associated disorders, like arterial occlusion or atherosclerotic plaques, became evident. Loss of PHD3 is known to enhance the innate immune response (Kiss et al., 2012) and regulate the life span of neutrophils under hypoxia (Walmsley et al., 2011). The specific role of PHD3 in macrophages however was less explained so far. For this purpose a myeloidspecific PHD3 knockout mouse has been established. 


\subsection{HIF target gene expression is unchanged in $\mathrm{PHD}^{-/-} \mathrm{BMDM}^{-1}$}

To investigate the role of PHD3 in BMDMs myeloid-specific $\mathrm{PHD}^{-/-}$mice were used. The myeloid-specific mouse line was generated using the conditional Cre/loxP knockout strategy. The Cre recombinase was expressed under the control of LysM promoter. Through this conditional knockout strategy I generated BMDMs with a knockout efficiency of roughly $75 \%$ (Fig. 13). The motive of using a conditional knockout is that it more or less resembles the pharmacological inhibition of the PHD enzymes. PHD enzymes are currently tested for their potential to be used as drug targets to stimulate HIF-dependent gene expression (Myllyharju, 2008). This strategy is developed for applications in the context of ischemia tissue protection and severe anemia (Katschinski, 2009). The strong hypoxic induction of PHD3 is even conserved in BMDMs which has already been described in myeloid cells in several publications (Rohrbach et al., 2005; Appelhoff et al., 2004; Walmsley et al., 2011) .

Knocking out PHD3 in myeloid cells affects neither the morphology nor the differentiation of 8 days differentiated BMDMs (Fig. 11 and Fig. 12). However the process of differentiation was altered in PHD3 ${ }^{-/}$ BMDMs observed by F4/80 and CD11b staining (Fig. 11). The $\mathrm{PHD}^{-/}$BMDM showed a higher differentiation efficiency over time. This is in line with an earlier study (Kiss et al., 2012) analyzing constitutive $\mathrm{PHD}^{-/}$BMDMs. My results confirmed that PHD3 might be involved in the differentiation process of macrophages.

The $\mathrm{PHD}^{-/-}$BMDM do not alter the expression of the other HIF-regulating isoforms of PHDs, i.e. PHD1 and PHD2, suggesting that no compensatory effect occurs (Fig. 14). In addition the knockout does not show increased HIF-1 $\alpha$ and HIF-2 $\alpha$ protein levels in normoxia and hypoxia (Fig. 15). Further, HIF target gene expression in the knockout macrophages do not seem to be regulated both in normoxic and hypoxic conditions, but as expected hypoxic induction of HIF target genes was confirmed (Fig. 16). Even in the unbiased transcriptome screen, I could indeed not find any significantly differentially expressed HIF target gene in the $\mathrm{PHD}^{-/-}$BMDM (Fig. 17). My results show that knocking out PHD3 in myeloid cells is not sufficient to affect HIF dependent pathways. 


\subsection{Macrophage polarization is unaffected in $\mathrm{PHD}^{-/-}$BMDM}

Plasticity and diversity are the known hallmarks of the monocyte-macrophage differentiation pathway. Macrophages have huge versatility and can change their phenotype upon stimulation (Mosser and Edwards, 2008). It has been described in the literature that macrophages can differentiate into two subpopulations, which carry out distinct but time overlapping functions. These subpopulations can be broadly categorized as classically activated macrophages (M1) which consist of the pro-inflammatory macrophage subset, induced by interferon- $\gamma$ and/or LPS and alternatively activated macrophages (M2) which consist of an anti-inflammatory macrophage subset induced by exposure to IL-4. M1 polarized macrophages are tissue destructive and remove the damaged tissue whereas M2 polarized macrophages induce tissue remodeling and angiogenesis (Fernando et al., 2014; Mosser and Edwards, 2008). The ability of macrophages to reprogram their function blurs in a way the distinction between innate and adaptive immune response. Moreover, evidence shows that the orchestration of macrophage function and polarization has a key role in different pathological conditions (Mantovani et al., 2004).

Literature suggests that both HIF-1 $\alpha$ and HIF-2 $\alpha$ affect macrophage polarization. It is known that hypoxia can lead to macrophage inflammatory functions, e.g the production of cytokines by macrophages increases under hypoxia. LPS treatment induces stabilization of HIFa in macrophages (Frede et al., 2006; Takeda et al., 2010). It has been shown that 5 day differentiated constitutively knocked out PHD3 macrophages are M1 polarized (Kiss et al., 2012). In contrast to this, my quantitative real-time PCR analysis showed no significant difference in induction of either M1 or M2 markers in $\mathrm{PHD}^{-/-}$macrophages (Fig. 19), nor does my protein expression analysis showed any difference in induction of cytokines upon exposure LPS, IFN $\gamma$ and IL-4 in $\mathrm{PHD}^{-/}$macrophages (Fig. 20). This suggests, that 8 days differentiated myeloid specific $\mathrm{PHD}^{-/-}$BMDMs are not significantly affected in their proinflammatory function. 


\subsection{NFKB activity is unaffected in $\mathrm{PHD3}^{-/-} \mathrm{BMDM}$}

NFKB regulates the expression of pro-inflammatory molecules including cytokines and chemokines (Balkwill and Mantovani, 2001). PHDs have been shown to impact in the regulation of NFKB (Cummins et al., 2006a). It has been demonstrated that PHDs are repressors of NFKB activity, via their potential to hydroxylate the IKB kinase (Cummins et al., 2006). Further it has been described that PHD3 can associate with IKK $\beta$ independently of its hydroxylase function, thereby blocking the interaction between IKK $\beta$ and HSP90, which is required for IKK $\beta$ phosphorylation and release of NFKB (Xue et al., 2010). In addition, loss of function studies indicate that PHD3 serves as a co-activator of NFKB signaling activity (Fujita et al., 2012). It was therefore then worthwhile to speculate that loss of PHD3 in my BMDMs might regulate NFkB activity (Hatada et al., 2000).

In my study, I could show that $\mathrm{PHD}^{-/}$BMDM do not have any obvious difference in NFKB activity compared to the wt cells (Fig. 18). Activation of macrophages with LPS treatment, however, showed less NFKB activity in $\mathrm{PHD}^{-/-}$BMDM, which is in line with the above referenced work that has uncovered mechanisms by which hypoxia modulates the activation of NFKB through decreased oxygen-dependent suppression of the key regulators of this pathway (Cummins et al., 2006; Scholz et al., 2013).

\subsection{PHD3 plays a pro-apoptotic role in BMDM}

A huge number of recent studies support the role of PHD3 in cell differentiation, survival, apoptosis, and metabolism. A clear role for PHD3 in neuronal apoptosis suggests that PHD3 mutations may be involved in the progression of neuronal malignancies. On the other hand, inhibition of PHD3 activity leads to survival of cancer cells (Lee et al., 2005). Apart from the role of PHD3 in other cell types, a major role of PHD3 on cell survival in myeloid cells is well described (Walmsley et al., 2011; Kiss et al., 2012). Also my analysis of cell survival in the conditional $\mathrm{PHD}^{-/-}$BMDM cells showed a pronounced apoptotic phenotype (Fig. 21). A major impact of PHD3 on cell survival is in line with the findings, that deficient PHD3 neutrophils are not significantly altered regarding their pro-inflammatory function but regarding their apoptotic phenotype (Walmsley et al., 2011). At the molecular level this has been associated with a 
PHD3-dependent regulation of KIF1 $\beta$, HCLK2, SIVA and ATF-4 (Schlisio et al., 2008; Walmsley et al., 2011; Xie et al., 2012; Koditz et al., 2007).

My studies demonstrated that under stress condition such as starvation $\mathrm{PHD}^{-{ }^{--}} \mathrm{BMDMs}$ have significantly lower DNA damage (Fig. 21). These results indicate that knocking out PHD3 in BMDM protects the cells from apoptosis under stress condition. To further confirm the impact of PHD3 on BMDM, I analyzed the membrane integrity of the cells (Fig. 22) and could confirm that PHD3 plays a pro-apoptotic role in BMDMs. Further I did experiments to investigate the BMDM viability, which showed an increased viability of the $\mathrm{PHD}^{-/}$BMDMs (Fig. 23). Apart from the role of starvation for PHD3 mediated apoptosis my results also revealed that $\mathrm{PHD}^{-/-}$BMDM are significantly more protected to other apoptotic inducers such as staurosporine which causes ER stress or SNAP which causes oxidative stress (Fig. 24). Taken together, the above results demonstrate for the first time that PHD3 is involved in cell survival decisions in macrophages.

\subsection{Loss of PHD3 affects the expression of Angptl2}

To get an insight into the underlying molecular mechanism of the pro-apoptotic role of PHD3 in BMDMs, I performed a transcriptome screen in collaboration with the Transkriptions Analyse Labor (TAL, University Medical Center Göttingen). In the unbiased screen, none of the known target genes of PHD3-dependent regulation like KIF1ß, HCLK2, SIVA and ATF-4 (Köditz et al., 2007; Schlisio et al., 2008; Walmsley et al., 2011; Xie et al., 2012) were differentially regulated compared to wt BMDM. In the screen, 26 genes were found to be significantly induced under starvation (Table 3.3) and 19 genes were down regulated in a quantitatively different extent comparing wt versus $\mathrm{PHD}^{-/}$BMDM (Table 3.4). Among these 45 genes, further gene cluster analysis revealed a cluster (i.e. Angptl2, Col8A1, Col5A1, KDELR3, MYL9 and PXDN), which is known to be co-regulated and is associated with the regulation of the secretory pathway. To further gain insight into the PHD3 mediated mechanism an experiment was performed involving the supernatant culture medium which contains the secreted proteins from the cells. The result revealed a loss of the anti-apoptotic phenotype in the $\mathrm{PHD}^{-/}$BMDM when treated with wt conditioned medium (Fig. 
27). This indicated that at least in part a secreted factor is involved in the PHD3-mediated response towards an apoptotic stimulus.

One candidate of the transcriptome screen, Angptl2 seemed to be a promising factor involved in regulating the PHD3 mediated response. A significant difference in the level of the secretory glycoprotein Angptl2 both at RNA and protein level was found (Fig. 28-30). Angiopoietin-like proteins are structurally similar to the angiopoietin group of proteins which contain a coiled-coil domain in the $\mathrm{N}$-terminus and a fibrinogen-like domain in the C-terminus. Angiopoietin-like proteins represent a multi-functional family of secreted factors with structural similarity to angiopoietin, a molecule with pro-angiogenic function (Kadomatsu et al., 2011). Angptl2 is also known to induce chronic inflammation (Tazume et al., 2012). Angptls do not bind to the Tie2 receptor, but it has recently been reported that the LILRB2 and PIRB are receptors for several Angptl family members (Zheng et al., 2012; Oike et al., 2004). Angptl2 is expressed in a variety of cells including monocytes, macrophages and in tumors (Okada et al., 2010; Aoi et al., 2011; Tazume et al., 2012). Angptl2 has been reported to have a myriad of functions that are involved in inflammation, metabolism, angiogenesis and cancer (Kanda et al., 2012; Tazume et al., 2012; Tabata et al., 2009). The data obtained in this study demonstrate that PHD3 affects the expression of Angptl2 both at protein and RNA levels (Figure 3.19-3.21). The results showed enhanced Angptl2 levels upon starvation but decreased Angptl2 expression in the $\mathrm{PHD}^{-/-}$macrophages. Not only with starvation but also other stress inducers such as the NO donor SNAP and the ER stress inducer staurosporine induce the expression of Angpt12. In contrast to that, the treatment of BMDMs with SNAP and staurosporine results in decreased expression of Angpt12 in PHD3 deficient BMDMs which earlier proved to have decreased apoptosis (Fig. 28 and Fig. 29). Additionally, $\mathrm{PHD}^{-/}$BMDM also showed significantly less secretion of Angptl2 into the culture supernatant (Fig. 30). Above results suggest that differential expression and secretion of Angptl2 might play a role in influencing the apoptotic phenotype of the $\mathrm{PHD}^{-/-}$BMDMs.

\subsection{Loss of Angptl2 attenuates BMDM apoptosis}

To analyze the functional role of the decreased expression of Angptl2 in $\mathrm{PHD}^{-/-}$BMDM and the antiapoptotic phenotype, our collaborator partner Prof. Yuichi Oike at Keio University, Japan investigated apoptosis in Angpt12/- BMDM. Previously, it has been reported that in macrophages Angpt12 increases the 
expression of pro-inflammatory cytokines and MMP-9 by activating an NFKB dependent cascade in infiltrating macrophages, which accelerates chronic inflammation and promotes destructive remodeling in the vessel wall (Tazume et al., 2012). In this study the apoptosis of macrophage was not studied. In zebrafish however, Angptl2 knockdown showed minor vascular defects in embryos and also played a critical anti-apoptotic role in endothelial cells (Kubota et al., 2005)

The impact of Angptl2 on macrophages during serum starvation was proven using the Angpt12 ${ }^{-/}$BMDM. These data demonstrated that Angpt12 ${ }^{-/}$BMDM showed decreased apoptosis compared to wt BMDM under serum-induced starvation (Fig. 31). Even upon treatment with other apoptotic stimuli such as SNAP and stauro Angptl2/- BMDM were significantly protected against apoptosis. The above results support the conclusion that the altered Angptl2 expression in $\mathrm{PHD}^{-/}$BMDM is functionally involved in the apoptosis phenotype. Along this line, the decreased Angptl2 expression in $\mathrm{PHD}^{-/}$macrophages under serum starvation mirrors the shut-down of a death-supporting factor.

\subsection{Angptl2 affects macrophage apoptosis}

To confirm whether the loss of an autocrine effect of Angptl2 alters the apoptotic phenotype of BMDM, I evaluated the effect of adding exogenous Angptl2 to the culture medium. Addition of recombinant Angpt12 reverses the cell protection phenotype and results in increase apoptosis of PHD3 ${ }^{-/}$BMDM (Fig. 32). Taking into account the high induction of Angptl2 after serum starvation in wt BMDM, this can be interpreted as an activation of a protective feedback mechanism. Angptl2 treatment resulted in increased apoptosis of $\mathrm{PHD}^{-/-}$BMDM (Fig. 32), suggesting that Angptl2 regulates BMDM apoptosis in an autocrine manner. Angptl2 treatment under serum starvation resulted in an anti-apoptotic effect in the wt BMDM. The anti-apoptotic function of Angptl2 is in line with previous reports in endothelial cells (Kubota et al., 2005). Most interestingly, in $\mathrm{PHD}^{-/}$BMDM the response was reverted to a pro-apoptotic effect. Angptl2 treatment increased the serum-starvation induced cell death of $\mathrm{PHD}^{-/-}$macrophages but did not affect cell viability under normal cell-culture conditions. This implies that Angptl2 is not per se a pro-apoptotic factor but interferes with the apoptosis pathway after the application of a stress stimulus. 
It has been previously reported, that Angpt|2 signals through integrin $\alpha 5 \beta 1$ and PIRB receptors (Okada et al., 2010) and that the $\alpha 5 \beta 1$ and PIRB are receptors for several Angptl family members (Zheng et al., 2012; Oike et al., 2004). Analysis of receptors expression showed no difference in the expression level of these receptors excluding that the expression of these is involved in the altered Angpt12 response (Fig. 33). 


\section{Conclusion and Outlook}

In the present thesis, results showed for the first time a functional connection between PHD3 and Angptl2. In this study myeloid-specific PHD3-deficient macrophages were investigated. The PHD3 ${ }^{-/}$BMDM did not show an altered expression of the two other HIF-regulating PHDs, i.e. PHD1 and PHD2. Also the knockout BMDM showed no altered/increased HIF-1 $\alpha$ or HIF-2 $\alpha$ protein levels in normoxia and hypoxia. Further, the results were substantiated by the fact that the HIF target gene expression was unaltered in the PHD3 ${ }^{-1-}$ BMDM compared to wt cells. Macrophage M1 and M2-polarization remained unaltered as well. PHD3 has been associated with apoptotic cell death mechanisms in various cell types. In this study, macrophages were investigated regarding differences in apoptosis using TUNEL and Annexin $V$ staining. TUNEL staining revealed under starvation a decrease in number of apoptotic $\mathrm{PHD}^{-/-}$macrophages as compared to wt. The same results were confirmed using the early apoptotic marker Annexin V. Treatment with apoptotic inducers such as SNAP and staurosporine confirmed that $\mathrm{PHD}^{-/}$macrophages are less apoptotic. In line calcein uptake results revealed that $\mathrm{PHD}^{-/-}$cells are significantly more viable compared to wt BMDM. When the supernatant medium from the cultured macrophages was exchanged between the genotypes after $24 \mathrm{hrs}$ of culture, $\mathrm{PHD}^{-/-}$macrophages showed more Annexin $\mathrm{V}$ staining indicating that at least in part a secreted factor is involved in the $\mathrm{PHD}^{-/}$apoptosis mechanism. In an unbiased transcriptome screen comparing starved wt and $\mathrm{PHD}^{-{ }^{-}}$BMDM, I found a significant difference in the starvation-induced Angptl2 RNA. These data demonstrate that PHD3 affects the production of Angpt12 and additionally influences the response towards this apoptosis modulating factor. Further, treatment with recombinant Angptl2 rescued the anti-apoptotic phenotype demonstrating that it is involved in the PHD3mediated response towards apoptotic stimuli in macrophages. My data was further strengthened by investigating apoptosis in Angpt12 ${ }^{-/}$BMDM, which showed decreased apoptosis compared to wt BMDM supporting the lower expression of Angptl2 in $\mathrm{PHD}^{-/-}$BMDM followed by decreased apoptosis. Taken together, my data demonstrate for the first time that PHD3 plays a critical role for cell survival decisions in macrophages. This includes apoptotic cell death induced by serum starvation, which mimics in part ischemic conditions but also treatment with stauro or the endogenous inducers of apoptosis like the NO donor SNAP or LPS. The anti-apoptotic effect in the PHD3 ${ }^{-/-}$BMDM is at least partially mediated by an 
altered production and response to Angpt12. Findings such that inhibition of PHD3 can boost the innate immune defense might be exploited for clinical treatment strategies. Further research on loss of PHD3 and its effect on myeloid cell apoptosis is important to be investigated in more detail to determine the outcome on damaged tissue repair and tissue remodeling. Since macrophages are responsible for the early immune response, the data imply that PHD3 may shape this response by altering the life expectancies of macrophages in inflamed and ischemic tissues. Regardless of underlying molecular mechanisms, the present findings, that loss of PHD3 results in an increased lifespan of macrophages might have consequences for the clinical outcome of inflamed tissues. 


\section{References}

Acker, T. \&Plate, K. H. (2003). Role of hypoxia in tumor angiogenesis-molecular and cellular angiogenic crosstalk. Cell and tissue research 314(1): 145-155.

Allen, D. B., Maguire, J. J., Mahdavian, M., Wicke, C., Marcocci, L., Scheuenstuhl, H., Chang, M., Le, A. X., Hopf, H. W. \&Hunt, T. K. (1997). Wound hypoxia and acidosis limit neutrophil bacterial killing mechanisms. Archives of surgery 132(9): 991-996.

Almendros, I., Montserrat, J. M., Torres, M., Gonzalez, C., Navajas, D. \&Farre, R. (2010). Changes in oxygen partial pressure of brain tissue in an animal model of obstructive apnea. Respiratory research 11: 3 doi: 10.1186/1465-9921-11-3.

Anderson, K., Nordquist, K. A., Gao, X., Hicks, K. C., Zhai, B., Gygi, S. P. \&Patel, T. B. (2011). Regulation of cellular levels of Sprouty 2 protein by prolyl hydroxylase domain and von Hippel-Lindau proteins. The Journal of biological chemistry 286(49): 42027-42036.

Aoi, J., Endo, M., Kadomatsu, T., Miyata, K., Nakano, M., Horiguchi, H., Ogata, A., Odagiri, H., Yano, M., Araki, K., Jinnin, M., Ito, T., Hirakawa, S., Ihn, H. \&Oike, Y. (2011). Angiopoietin-like protein 2 is an important facilitator of inflammatory carcinogenesis and metastasis. Cancer research $71(24)$ : 7502-7512.

Appelhoff, R. J., Tian, Y. M., Raval, R. R., Turley, H., Harris, A. L., Pugh, C. W., Ratcliffe, P. J. \&Gleadle, J. M. (2004). Differential function of the prolyl hydroxylases PHD1, PHD2, and PHD3 in the regulation of hypoxia-inducible factor. The Journal of biological chemistry 279(37): 38458-38465.

Aragones, J., Schneider, M., Van Geyte, K., Fraisl, P., Dresselaers, T., Mazzone, M., Dirkx, R., Zacchigna, S., Lemieux, H., Jeoung, N. H., Lambrechts, D., Bishop, T., Lafuste, P., Diez-Juan, A., Harten, S. K., Van Noten, P., De Bock, K., Willam, C., Tjwa, M., Grosfeld, A., Navet, R., Moons, L., Vandendriessche, T., Deroose, C., Wijeyekoon, B., Nuyts, J., Jordan, B., Silasi-Mansat, R., Lupu, F., Dewerchin, M., Pugh, C., Salmon, P., Mortelmans, L., Gallez, B., Gorus, F., Buyse, J., Sluse, F., Harris, R. A., Gnaiger, E., Hespel, P., Van Hecke, P., Schuit, F., Van Veldhoven, P., Ratcliffe, P., Baes, M., Maxwell, P. \&Carmeliet, P. (2008). Deficiency or inhibition of oxygen sensor Phd1 induces hypoxia tolerance by reprogramming basal metabolism. Nature genetics 40(2): 170-180.

Azzawi, M., Kan, S. W., Hillier, V., Yonan, N., Hutchinson, I. V. \&Hasleton, P. S. (2005). The distribution of cardiac macrophages in myocardial ischaemia and cardiomyopathy. Histopathology 46(3): 314319.

Balamurugan, K., Luu, V. D., Kaufmann, M. R., Hofmann, V. S., Boysen, G., Barth, S., Bordoli, M. R., Stiehl, D. P., Moch, H., Schraml, P., Wenger, R. H. \&Camenisch, G. (2009). Onconeuronal cerebellar degeneration-related antigen, $\mathrm{Cdr} 2$, is strongly expressed in papillary renal cell carcinoma and leads to attenuated hypoxic response. Oncogene 28(37): 3274-3285.

Balkwill, F. \&Mantovani, A. (2001). Inflammation and cancer: back to Virchow Lancet 357(9255): 539545.

Barth, S., Edlich, F., Berchner-Pfannschmidt, U., Gneuss, S., Jahreis, G., Hasgall, P. A., Fandrey, J., Wenger, R. H. \&Camenisch, G. (2009). Hypoxia-inducible factor prolyl-4-hydroxylase PHD2 protein abundance depends on integral membrane anchoring of FKBP38. The Journal of biological chemistry 284(34): 23046-23058.

Bishop, T., Gallagher, D., Pascual, A., Lygate, C. A., de Bono, J. P., Nicholls, L. G., Ortega-Saenz, P., Oster, H., Wijeyekoon, B., Sutherland, A. I., Grosfeld, A., Aragones, J., Schneider, M., van Geyte, K., Teixeira, D., Diez-Juan, A., Lopez-Barneo, J., Channon, K. M., Maxwell, P. H., Pugh, C. W., Davies, A. M., Carmeliet, P. \&Ratcliffe, P. J. (2008). Abnormal sympathoadrenal development and systemic hypotension in $\mathrm{PHD}^{-/-}$mice. Molecular and cellular biology 28(10): 3386-3400.

Boehler, R. M., Graham, J. G. \&Shea, L. D. (2011). Tissue engineering tools for modulation of the immune response. BioTechniques 51(4): 239-240, 242, 244. 
Bruick, R. K. \&McKnight, S. L. (2001). A conserved family of prolyl-4-hydroxylases that modify HIF. Science 294(5545): 1337-1340.

Burgess, A. W., Metcalf, D., Kozka, I. J., Simpson, R. J., Vairo, G., Hamilton, J. A. \&Nice, E. C. (1985). Purification of two forms of colony-stimulating factor from mouse L-cell-conditioned medium. Journal of Biological Chemistry 260(29): 16004-16011.

Burke, B., Giannoudis, A., Corke, K. P., Gill, D., Wells, M., Ziegler-Heitbrock, L. \&Lewis, C. E. (2003). Hypoxia-induced gene expression in human macrophages: implications for ischemic tissues and hypoxia-regulated gene therapy. The American journal of pathology 163(4): 1233-1243.

Carreau, A., El Hafny-Rahbi, B., Matejuk, A., Grillon, C. \&Kieda, C. (2011). Why is the partial oxygen pressure of human tissues a crucial parameter? Small molecules and hypoxia. Journal of cellular and molecular medicine 15(6): 1239-1253.

Centanin, L., Ratcliffe, P. J. \&Wappner, P. (2005). Reversion of lethality and growth defects in Fatiga oxygen-sensor mutant flies by loss of hypoxia-inducible factor- $\alpha$ /Sima. EMBO reports $6(11)$ : 1070-1075.

Chen, J., Zhao, S., Nakada, K., Kuge, Y., Tamaki, N., Okada, F., Wang, J., Shindo, M., Higashino, F., Takeda, K., Asaka, M., Katoh, H., Sugiyama, T., Hosokawa, M. \&Kobayashi, M. (2003). Dominant-negative hypoxia-inducible factor-1 $\alpha$ reduces tumorigenicity of pancreatic cancer cells through the suppression of glucose metabolism. The American journal of pathology 162(4): 1283-1291.

Chen, N., Rinner, O., Czernik, D., Nytko, K. J., Zheng, D., Stiehl, D. P., Zamboni, N., Gstaiger, M. \&Frei, C. (2011a). The oxygen sensor PHD3 limits glycolysis under hypoxia via direct binding to pyruvate kinase. Cell research 21(6): 983-986.

Chen, S., Zhang, J., Li, X., Luo, X., Fang, J. \&Chen, H. (2011b). The expression of prolyl hydroxylase domain enzymes are up-regulated and negatively correlated with $\mathrm{Bcl}-2$ in non-small cell lung cancer. Molecular and cellular biochemistry 358(1-2): 257-263.

Clausen, B. E., Burkhardt, C., Reith, W., Renkawitz, R. \&Forster, I. (1999). Conditional gene targeting in macrophages and granulocytes using LysMcre mice. Transgenic Res 8(4): 265-277.

Cramer, T., Yamanishi, Y., Clausen, B. E., Forster, I., Pawlinski, R., Mackman, N., Haase, V. H., Jaenisch, R., Corr, M., Nizet, V., Firestein, G. S., Gerber, H. P., Ferrara, N. \&Johnson, R. S. (2003). HIF-1 $\alpha$ is essential for myeloid cell-mediated inflammation. Cell 112(5): 645-657.

Cummins, E. P., Berra, E., Comerford, K. M., Ginouves, A., Fitzgerald, K. T., Seeballuck, F., Godson, C., Nielsen, J. E., Moynagh, P., Pouyssegur, J. \&Taylor, C. T. (2006). Prolyl hydroxylase-1 negatively regulates IKB kinase- $\beta$, giving insight into hypoxia-induced NFKB activity. Proceedings of the National Academy of Sciences of the United States of America 103(48): 18154-18159.

Davis, S., Aldrich, T. H., Jones, P. F., Acheson, A., Compton, D. L., Jain, V., Ryan, T. E., Bruno, J., Radziejewski, C., Maisonpierre, P. C. \&Yancopoulos, G. D. (1996). Isolation of angiopoietin-1, a ligand for the TIE2 receptor, by secretion-trap expression cloning. Cell 87(7): 1161-1169.

Dunwoodie, S. L. (2009). The role of hypoxia in development of the Mammalian embryo. Developmental cell 17(6): 755-773.

Elkins, J. M., Hewitson, K. S., McNeill, L. A., Seibel, J. F., Schlemminger, I., Pugh, C. W., Ratcliffe, P. J. \&Schofield, C. J. (2003). Structure of factor-inhibiting hypoxia-inducible factor (HIF) reveals mechanism of oxidative modification of HIF-1 $\alpha$. The Journal of biological chemistry 278(3): 18021806.

Eltzschig, H. K. \&Carmeliet, P. (2011). Hypoxia and inflammation. The New England journal of medicine 364(7): 656-665.

Ema, M., Taya, S., Yokotani, N., Sogawa, K., Matsuda, Y. \&Fujii-Kuriyama, Y. (1997). A novel bHLH-PAS factor with close sequence similarity to hypoxia-inducible factor $1 \alpha$ regulates the VEGF expression and is potentially involved in lung and vascular development. Proceedings of the National Academy of Sciences of the United States of America 94(9): 4273-4278. 
Endo, M., Nakano, M., Kadomatsu, T., Fukuhara, S., Kuroda, H., Mikami, S., Hato, T., Aoi, J., Horiguchi, H., Miyata, K., Odagiri, H., Masuda, T., Harada, M., Horio, H., Hishima, T., Nomori, H., Ito, T., Yamamoto, Y., Minami, T., Okada, S., Takahashi, T., Mochizuki, N., Iwase, H. \&Oike, Y. (2012). Tumor cell-derived angiopoietin-like protein ANGPTL2 is a critical driver of metastasis. Cancer research 72(7): 1784-1794.

Epstein, A. C., Gleadle, J. M., McNeill, L. A., Hewitson, K. S., O'Rourke, J., Mole, D. R., Mukherji, M., Metzen, E., Wilson, M. I., Dhanda, A., Tian, Y. M., Masson, N., Hamilton, D. L., Jaakkola, P., Barstead, R., Hodgkin, J., Maxwell, P. H., Pugh, C. W., Schofield, C. J. \&Ratcliffe, P. J. (2001). C. elegans EGL-9 and mammalian homologs define a family of dioxygenases that regulate HIF by prolyl hydroxylation. Cell 107(1): 43-54.

Fernando, M. R., Reyes, J. L., lannuzzi, J., Leung, G. \&McKay, D. M. (2014). The pro-inflammatory cytokine, interleukin- 6 , enhances the polarization of alternatively activated macrophages. PloS one 9(4): e94188.

Flamant, L., Notte, A., Ninane, N., Raes, M. \&Michiels, C. (2010). Anti-apoptotic role of HIF-1 and AP-1 in paclitaxel exposed breast cancer cells under hypoxia. Molecular cancer 9: 191 . doi: 10.1186/1476-4598-9-191

Fong, G. H. (2009). Regulation of angiogenesis by oxygen sensing mechanisms. Journal of molecular medicine 87(6): 549-560.

Frede, S., Stockmann, C., Freitag, P. \&Fandrey, J. (2006). Bacterial lipopolysaccharide induces HIF-1 activation in human monocytes via p44/42 MAPK and NF-KB. The Biochemical journal 396(3): 517-527.

Fu, J., Menzies, K., Freeman, R. S. \&Taubman, M. B. (2007). EGLN3 prolyl hydroxylase regulates skeletal muscle differentiation and myogenin protein stability. The Journal of biological chemistry 282(17): 12410-12418.

Fu, J. \&Taubman, M. B. (2010). Prolyl hydroxylase EGLN3 regulates skeletal myoblast differentiation through an NF-KB-dependent pathway. The Journal of biological chemistry 285(12): 8927-8935.

Fu, J. \&Taubman, M. B. (2013). EGLN3 inhibition of NF-KB is mediated by prolyl hydroxylase-independent inhibition of IKB kinase $\gamma$ ubiquitination. Molecular and cellular biology 33(15): 3050-3061.

Fujita, N., Gogate, S. S., Chiba, K., Toyama, Y., Shapiro, I. M. \&Risbud, M. V. (2012). Prolyl hydroxylase 3 (PHD3) modulates catabolic effects of tumor necrosis factor- $\alpha$ (TNF- $\alpha$ ) on cells of the nucleus pulposus through co-activation of nuclear factor $\mathrm{kB}(\mathrm{NF}-\mathrm{kB}) / \mathrm{p} 65$ signaling. The Journal of biological chemistry 287(47): 39942-39953.

Garvey, C., Tiep, B., Carter, R., Barnett, M., Hart, M. \&Casaburi, R. (2012). Severe exercise-induced hypoxemia. Respiratory care 57(7): 1154-1160.

Gu, Y. Z., Moran, S. M., Hogenesch, J. B., Wartman, L. \&Bradfield, C. A. (1998). Molecular characterization and chromosomal localization of a third $\alpha$-class hypoxia inducible factor subunit, HIF3 $\alpha$. Gene expression 7(3): 205-213.

Hara, S., Hamada, J., Kobayashi, C., Kondo, Y. \&Imura, N. (2001). Expression and characterization of hypoxia-inducible factor (HIF)-3 $\alpha$ in human kidney: suppression of HIF-mediated gene expression by HIF-3 $\alpha$. Biochemical and biophysical research communications 287(4): 808-813.

Hatada, E. N., Krappmann, D. \&Scheidereit, C. (2000). NF-KB and the innate immune response. Current opinion in immunology 12(1): 52-58.

Hato, T., Tabata, M. \&Oike, Y. (2008). The role of angiopoietin-like proteins in angiogenesis and metabolism. Trends in cardiovascular medicine 18(1): 6-14.

Hirsila, M., Koivunen, P., Gunzler, V., Kivirikko, K. I. \&Myllyharju, J. (2003). Characterization of the human prolyl 4-hydroxylases that modify the hypoxia-inducible factor. The Journal of biological chemistry 278(33): 30772-30780. 
Hiwatashi, Y., Kanno, K., Takasaki, C., Goryo, K., Sato, T., Torii, S., Sogawa, K. \&Yasumoto, K. (2011). PHD1 interacts with ATF4 and negatively regulates its transcriptional activity without prolyl hydroxylation. Experimental cell research 317(20): 2789-2799.

Hogel, H., Rantanen, K., Jokilehto, T., Grenman, R. \&Jaakkola, P. M. (2011). Prolyl hydroxylase PHD3 enhances the hypoxic survival and G1 to $S$ transition of carcinoma cells. PloS one 6(11): e27112.

Hopfer, U., Hopfer, H., Jablonski, K., Stahl, R. A. \&Wolf, G. (2006). The novel WD-repeat protein Morg1 acts as a molecular scaffold for hypoxia-inducible factor prolyl hydroxylase 3 (PHD3). The Journal of biological chemistry 281(13): 8645-8655.

Huang, J., Song, D., Flores, A., Zhao, Q., Mooney, S. M., Shaw, L. M. \&Lee, F. S. (2007). IOP1, a novel hydrogenase-like protein that modulates hypoxia-inducible factor-1 $\alpha$ activity. The Biochemical journal 401(1): 341-352.

Huang, J., Zhao, Q., Mooney, S. M. \&Lee, F. S. (2002). Sequence determinants in hypoxia-inducible factor$1 \alpha$ for hydroxylation by the prolyl hydroxylases PHD1, PHD2, and PHD3. The Journal of biological chemistry 277(42): 39792-39800.

Huang, L. E., Gu, J., Schau, M. \&Bunn, H. F. (1998). Regulation of hypoxia-inducible factor $1 \alpha$ is mediated by an $\mathrm{O}_{2}$-dependent degradation domain via the ubiquitin-proteasome pathway. Proceedings of the National Academy of Sciences of the United States of America 95(14): 7987-7992.

Huo, Z., Ye, J. C., Chen, J., Lin, X., Zhou, Z. N., Xu, X. R., Li, C. M., Qi, M., Liang, D., Liu, Y. \&Li, J. (2012). Prolyl hydroxylase domain protein 2 regulates the intracellular cyclic AMP level in cardiomyocytes through its interaction with phosphodiesterase 4D. Biochemical and biophysical research communications 427(1): 73-79.

Imtiyaz, H. Z., Williams, E. P., Hickey, M. M., Patel, S. A., Durham, A. C., Yuan, L. J., Hammond, R., Gimotty, P. A., Keith, B. \&Simon, M. C. (2010). Hypoxia-inducible factor $2 \alpha$ regulates macrophage function in mouse models of acute and tumor inflammation. The Journal of clinical investigation 120(8): 2699-2714.

Jaakkola, P., Mole, D. R., Tian, Y. M., Wilson, M. I., Gielbert, J., Gaskell, S. J., von Kriegsheim, A., Hebestreit, H. F., Mukherji, M., Schofield, C. J., Maxwell, P. H., Pugh, C. W. \&Ratcliffe, P. J. (2001). Targeting of HIF- $\alpha$ to the von Hippel-Lindau ubiquitylation complex by $\mathrm{O}_{2}$-regulated prolyl hydroxylation. Science 292(5516): 468-472.

Jaakkola, P. M. \&Rantanen, K. (2013). The regulation, localization, and functions of oxygen-sensing prolyl hydroxylase PHD3. Biological chemistry 394(4): 449-457.

Josko, J., Gwozdz, B., Jedrzejowska-Szypulka, H. \&Hendryk, S. (2000). Vascular endothelial growth factor (VEGF) and its effect on angiogenesis. Medical science monitor: international medical journal of experimental and clinical research 6(5): 1047-1052.

Jurgensen, J. S., Rosenberger, C., Wiesener, M. S., Warnecke, C., Horstrup, J. H., Grafe, M., Philipp, S., Griethe, W., Maxwell, P. H., Frei, U., Bachmann, S., Willenbrock, R. \&Eckardt, K. U. (2004). Persistent induction of HIF- $1 \alpha$ and $-2 \alpha$ in cardiomyocytes and stromal cells of ischemic myocardium. FASEB journal 18(12): 1415-1417.

Kadomatsu, T., Tabata, M. \&Oike, Y. (2011). Angiopoietin-like proteins: emerging targets for treatment of obesity and related metabolic diseases. The FEBS journal 278(4): 559-564.

Kallio, P. J., Pongratz, I., Gradin, K., McGuire, J. \&Poellinger, L. (1997). Activation of hypoxia-inducible factor $1 \alpha$ : posttranscriptional regulation and conformational change by recruitment of the Arnt transcription factor. Proceedings of the National Academy of Sciences of the United States of America 94(11): 5667-5672.

Kallio, P. J., Wilson, W. J., O'Brien, S., Makino, Y. \&Poellinger, L. (1999). Regulation of the hypoxiainducible transcription factor $1 \alpha$ by the ubiquitin-proteasome pathway. The Journal of biological chemistry 274(10): 6519-6525. 
Kanda, A., Noda, K., Oike, Y. \&lshida, S. (2012). Angiopoietin-like protein 2 mediates endotoxin-induced acute inflammation in the eye. Laboratory investigation; a journal of technical methods and pathology 92(11): 1553-1563.

Katschinski, D. M. (2009). In vivo functions of the prolyl-4-hydroxylase domain oxygen sensors: direct route to the treatment of anaemia and the protection of ischaemic tissues. Acta physiologica 195(4): 407-414.

Ke, Q. \&Costa, M. (2006). Hypoxia-inducible factor-1 (HIF-1). Molecular pharmacology 70(5): 1469-1480.

Kent, B. D., Mitchell, P. D. \&McNicholas, W. T. (2011). Hypoxemia in patients with COPD: cause, effects, and disease progression. International journal of chronic obstructive pulmonary disease 6: 199208.

Kiss, J., Mollenhauer, M., Walmsley, S. R., Kirchberg, J., Radhakrishnan, P., Niemietz, T., Dudda, J., Steinert, G., Whyte, M. K., Carmeliet, P., Mazzone, M., Weitz, J. \&Schneider, M. (2012). Loss of the oxygen sensor PHD3 enhances the innate immune response to abdominal sepsis. Journal of immunology 189(4): 1955-1965.

Köditz, J., Nesper, J., Wottawa, M., Stiehl, D. P., Camenisch, G., Franke, C., Myllyharju, J., Wenger, R. H. \&Katschinski, D. M. (2007). Oxygen-dependent ATF-4 stability is mediated by the PHD3 oxygen sensor. Blood 110(10): 3610-3617.

Koh, M. Y., Lemos, R., Jr., Liu, X. \&Powis, G. (2011). The hypoxia-associated factor switches cells from HIF$1 \alpha$ - to HIF-2 $\alpha$-dependent signaling promoting stem cell characteristics, aggressive tumor growth and invasion. Cancer research 71(11): 4015-4027.

Koh, M. Y. \&Powis, G. (2012). Passing the baton: the HIF switch. Trends in biochemical sciences 37(9): 364-372.

Koivunen, P., Hirsila, M., Gunzler, V., Kivirikko, K. I. \&Myllyharju, J. (2004). Catalytic properties of the asparaginyl hydroxylase (FIH) in the oxygen sensing pathway are distinct from those of its prolyl 4-hydroxylases. The Journal of biological chemistry 279(11): 9899-9904.

Kubota, Y., Oike, Y., Satoh, S., Tabata, Y., Niikura, Y., Morisada, T., Akao, M., Urano, T., Ito, Y., Miyamoto, T., Nagai, N., Koh, G. Y., Watanabe, S. \&Suda, T. (2005). Cooperative interaction of Angiopoietinlike proteins 1 and 2 in zebrafish vascular development. Proceedings of the National Academy of Sciences of the United States of America 102(38): 13502-13507.

Lando, D., Peet, D. J., Gorman, J. J., Whelan, D. A., Whitelaw, M. L. \&Bruick, R. K. (2002). FIH-1 is an asparaginyl hydroxylase enzyme that regulates the transcriptional activity of hypoxia-inducible factor. Genes \& development 16(12): 1466-1471.

Lee, S., Nakamura, E., Yang, H., Wei, W., Linggi, M. S., Sajan, M. P., Farese, R. V., Freeman, R. S., Carter, B. D., Kaelin, W. G., Jr. \&Schlisio, S. (2005). Neuronal apoptosis linked to EgIN3 prolyl hydroxylase and familial pheochromocytoma genes: developmental culling and cancer. Cancer cell 8(2): 155167.

Lee, Y. M., Jeong, C. H., Koo, S. Y., Son, M. J., Song, H. S., Bae, S. K., Raleigh, J. A., Chung, H. Y., Yoo, M. A. \&Kim, K. W. (2001). Determination of hypoxic region by hypoxia marker in developing mouse embryos in vivo: a possible signal for vessel development. Dev Dyn 220(2): 175-186.

Lewis, J. S., Landers, R. J., Underwood, J. C., Harris, A. L. \&Lewis, C. E. (2000). Expression of vascular endothelial growth factor by macrophages is up-regulated in poorly vascularized areas of breast carcinomas. The Journal of pathology 192(2): 150-158.

Lieb, M. E., Menzies, K., Moschella, M. C., Ni, R. \&Taubman, M. B. (2002). Mammalian EGLN genes have distinct patterns of mRNA expression and regulation. Biochemistry and cell biology 80(4): 421426.

Lipscomb, E. A., Sarmiere, P. D., Crowder, R. J. \&Freeman, R. S. (1999). Expression of the SM-20 gene promotes death in nerve growth factor-dependent sympathetic neurons. Journal of neurochemistry 73(1): 429-432. 
Lipscomb, E. A., Sarmiere, P. D. \&Freeman, R. S. (2001). SM-20 is a novel mitochondrial protein that causes caspase-dependent cell death in nerve growth factor-dependent neurons. The Journal of biological chemistry 276(7): 5085-5092.

Liu, Y., Huo, Z., Yan, B., Lin, X., Zhou, Z. N., Liang, X., Zhu, W., Liang, D., Li, L., Zhao, H., Sun, Y. \&Chen, Y. H. (2010). Prolyl hydroxylase 3 interacts with Bcl-2 to regulate doxorubicin-induced apoptosis in H9c2 cells. Biochemical and biophysical research communications 401(2): 231-237.

Luo, W., Hu, H., Chang, R., Zhong, J., Knabel, M., O'Meally, R., Cole, R. N., Pandey, A. \&Semenza, G. L. (2011). Pyruvate kinase M2 is a PHD3-stimulated coactivator for hypoxia-inducible factor 1. Cell 145(5): 732-744.

Madden, S. L., Galella, E. A., Riley, D., Bertelsen, A. H. \&Beaudry, G. A. (1996). Induction of cell growth regulatory genes by p53. Cancer research 56(23): 5384-5390.

Mahon, P. C., Hirota, K. \&Semenza, G. L. (2001). FIH-1: a novel protein that interacts with HIF-1 $\alpha$ and VHL to mediate repression of HIF-1 transcriptional activity. Genes \& development 15(20): 2675-2686.

Makino, Y., Kanopka, A., Wilson, W. J., Tanaka, H. \&Poellinger, L. (2002). Inhibitory PAS domain protein (IPAS) is a hypoxia-inducible splicing variant of the hypoxia-inducible factor-3 $\alpha$ locus. The Journal of biological chemistry 277(36): 32405-32408.

Mantovani, A., Sica, A., Sozzani, S., Allavena, P., Vecchi, A. \&Locati, M. (2004). The chemokine system in diverse forms of macrophage activation and polarization. Trends in immunology 25(12): 677-686.

Masson, N., Appelhoff, R. J., Tuckerman, J. R., Tian, Y. M., Demol, H., Puype, M., Vandekerckhove, J., Ratcliffe, P. J. \&Pugh, C. W. (2004). The HIF prolyl hydroxylase PHD3 is a potential substrate of the TRiC chaperonin. FEBS letters 570(1-3): 166-170.

Masson, N. \&Ratcliffe, P. J. (2003). HIF prolyl and asparaginyl hydroxylases in the biological response to intracellular O(2) levels. Journal of Cell Science 116(Pt 15): 3041-3049.

Mazzone, M., Dettori, D., Leite de Oliveira, R., Loges, S., Schmidt, T., Jonckx, B., Tian, Y. M., Lanahan, A. A., Pollard, P., Ruiz de Almodovar, C., De Smet, F., Vinckier, S., Aragones, J., Debackere, K., Luttun, A., Wyns, S., Jordan, B., Pisacane, A., Gallez, B., Lampugnani, M. G., Dejana, E., Simons, M., Ratcliffe, P., Maxwell, P. \&Carmeliet, P. (2009). Heterozygous deficiency of PHD2 restores tumor oxygenation and inhibits metastasis via endothelial normalization. Cell 136(5): 839-851.

McDonough, M. A., Li, V., Flashman, E., Chowdhury, R., Mohr, C., Lienard, B. M., Zondlo, J., Oldham, N. J., Clifton, I. J., Lewis, J., McNeill, L. A., Kurzeja, R. J., Hewitson, K. S., Yang, E., Jordan, S., Syed, R. S. \&Schofield, C. J. (2006). Cellular oxygen sensing: Crystal structure of hypoxia-inducible factor prolyl hydroxylase (PHD2). Proceedings of the National Academy of Sciences of the United States of America 103(26): 9814-9819.

Metzen, E., Berchner-Pfannschmidt, U., Stengel, P., Marxsen, J. H., Stolze, I., Klinger, M., Huang, W. Q., Wotzlaw, C., Hellwig-Burgel, T., Jelkmann, W., Acker, H. \&Fandrey, J. (2003). Intracellular localisation of human HIF-1 a $\alpha$ hydroxylases: implications for oxygen sensing. Journal of Cell Science 116(Pt 7): 1319-1326.

Mikhaylova, O., Ignacak, M. L., Barankiewicz, T. J., Harbaugh, S. V., Yi, Y., Maxwell, P. H., Schneider, M., Van Geyte, K., Carmeliet, P., Revelo, M. P., Wyder, M., Greis, K. D., Meller, J. \&Czyzyk-Krzeska, M. F. (2008). The von Hippel-Lindau tumor suppressor protein and Egl-9-Type proline hydroxylases regulate the large subunit of RNA polymerase II in response to oxidative stress. Molecular and cellular biology 28(8): 2701-2717.

Mora, A., Sakamoto, K., McManus, E. J. \&Alessi, D. R. (2005). Role of the PDK1-PKB-GSK3 pathway in regulating glycogen synthase and glucose uptake in the heart. FEBS letters 579(17): 3632-3638.

Mosser, D. M. \&Edwards, J. P. (2008). Exploring the full spectrum of macrophage activation. Nature reviews. Immunology 8(12): 958-969.

Myllyharju, J. (2008). Prolyl 4-hydroxylases, key enzymes in the synthesis of collagens and regulation of the response to hypoxia, and their roles as treatment targets. Annals of medicine 40(6): 402-417. 
Nakayama, K., Gazdoiu, S., Abraham, R., Pan, Z. Q. \&Ronai, Z. (2007). Hypoxia-induced assembly of prolyl hydroxylase PHD3 into complexes: implications for its activity and susceptibility for degradation by the E3 ligase Siah2. The Biochemical journal 401(1): 217-226.

Nakayama, K., Qi, J. \&Ronai, Z. (2009). The ubiquitin ligase Siah2 and the hypoxia response. Molecular cancer research : $M C R$ 7(4): 443-451.

Ohh, M., Park, C. W., Ivan, M., Hoffman, M. A., Kim, T. Y., Huang, L. E., Pavletich, N., Chau, V. \&Kaelin, W. G. (2000). Ubiquitination of hypoxia-inducible factor requires direct binding to the $\beta$-domain of the von Hippel-Lindau protein. Nature cell biology 2(7): 423-427.

Oike, Y., Yasunaga, K. \&Suda, T. (2004). Angiopoietin-related/angiopoietin-like proteins regulate angiogenesis. International Journal of Hematology 80(1): 21-28.

Okada, T., Tsukano, H., Endo, M., Tabata, M., Miyata, K., Kadomatsu, T., Miyashita, K., Semba, K., Nakamura, E., Tsukano, M., Mizuta, H. \&Oike, Y. (2010). Synoviocyte-derived angiopoietin-like protein 2 contributes to synovial chronic inflammation in rheumatoid arthritis. The American journal of pathology 176(5): 2309-2319.

Ozer, A., Wu, L. C. \&Bruick, R. K. (2005). The candidate tumor suppressor ING4 represses activation of the hypoxia inducible factor (HIF). Proceedings of the National Academy of Sciences of the United States of America 102(21): 7481-7486.

Park, E. C., Ghose, P., Shao, Z., Ye, Q., Kang, L., Xu, X. Z., Powell-Coffman, J. A. \&Rongo, C. (2012). Hypoxia regulates glutamate receptor trafficking through an HIF-independent mechanism. The EMBO journal 31(6): 1379-1393.

Percy, M. J., Zhao, Q., Flores, A., Harrison, C., Lappin, T. R., Maxwell, P. H., McMullin, M. F. \&Lee, F. S. (2006). A family with erythrocytosis establishes a role for prolyl hydroxylase domain protein 2 in oxygen homeostasis. Proceedings of the National Academy of Sciences of the United States of America 103(3): 654-659.

Pescador, N., Cuevas, Y., Naranjo, S., Alcaide, M., Villar, D., Landazuri, M. O. \&Del Peso, L. (2005). Identification of a functional hypoxia-responsive element that regulates the expression of the egl nine homologue 3 (egln3/phd3) gene. The Biochemical journal 390(Pt 1): 189-197.

Peyssonnaux, C., Datta, V., Cramer, T., Doedens, A., Theodorakis, E. A., Gallo, R. L., Hurtado-Ziola, N., Nizet, V. \&Johnson, R. S. (2005). HIF-1 $\alpha$ expression regulates the bactericidal capacity of phagocytes. The Journal of clinical investigation 115(7): 1806-1815.

Place, T. L. \&Domann, F. E. (2013). Prolyl-hydroxylase 3: Evolving Roles for an Ancient Signaling Protein. Hypoxia 2013(1): 13-17.

Pugh, C. W. \&Ratcliffe, P. J. (2003). Regulation of angiogenesis by hypoxia: role of the HIF system. Nature medicine 9(6): 677-684.

Qiao, M., Rushforth, D., Wang, R., Shaw, R. A., Tomanek, B., Dunn, J. F. \&Tuor, U. I. (2007). Blood-oxygenlevel-dependent magnetic resonance signal and cerebral oxygenation responses to brain activation are enhanced by concurrent transient hypertension in rats. Journal of cerebral blood flow and metabolism 27(6): 1280-1289.

Rantanen, K., Pursiheimo, J., Hogel, H., Himanen, V., Metzen, E. \&Jaakkola, P. M. (2008). Prolyl hydroxylase PHD3 activates oxygen-dependent protein aggregation. Molecular biology of the cell 19(5): 2231-2240.

Regula, K. M. (2002). Inducible Expression of BNIP3 Provokes Mitochondrial Defects and HypoxiaMediated Cell Death of Ventricular Myocytes. Circulation research 91(3): 226-231.

Rohrbach, S., Simm, A., Pregla, R., Franke, C. \&Katschinski, D. M. (2005). Age-dependent increase of prolyl-4-hydroxylase domain (PHD) 3 expression in human and mouse heart. Biogerontology 6(3): 165-171.

Ross, J. A. \&Rosen, G. D. (2002). The molecular biology of lung cancer. Current opinion in pulmonary medicine 8(4): 265-269. 
Roy, A., Volgin, D. V., Baby, S. M., Mokashi, A., Kubin, L. \&Lahiri, S. (2004). Activation of HIF-1 $\alpha$ mRNA by hypoxia and iron chelator in isolated rat carotid body. Neuroscience letters 363(3): 229-232.

Salceda, S. \&Caro, J. (1997). Hypoxia-inducible factor $1 \alpha$ (HIF-1 $\alpha$ ) protein is rapidly degraded by the ubiquitin-proteasome system under normoxic conditions. Its stabilization by hypoxia depends on redox-induced changes. The Journal of biological chemistry 272(36): 22642-22647.

Sato, M., Sakota, M. \&Nakayama, K. (2010). Human PRP19 interacts with prolyl-hydroxylase PHD3 and inhibits cell death in hypoxia. Experimental cell research 316(17): 2871-2882.

Schlisio, S., Kenchappa, R. S., Vredeveld, L. C., George, R. E., Stewart, R., Greulich, H., Shahriari, K., Nguyen, N. V., Pigny, P., Dahia, P. L., Pomeroy, S. L., Maris, J. M., Look, A. T., Meyerson, M., Peeper, D. S., Carter, B. D. \&Kaelin, W. G., Jr. (2008). The kinesin KIF1B $\beta$ acts downstream from EgIN3 to induce apoptosis and is a potential 1 p36 tumor suppressor. Genes \& development 22(7): 884-893.

Schneider, M., Van Geyte, K., Fraisl, P., Kiss, J., Aragones, J., Mazzone, M., Mairbaurl, H., De Bock, K., Jeoung, N. H., Mollenhauer, M., Georgiadou, M., Bishop, T., Roncal, C., Sutherland, A., Jordan, B., Gallez, B., Weitz, J., Harris, R. A., Maxwell, P., Baes, M., Ratcliffe, P. \&Carmeliet, P. (2010). Loss or silencing of the PHD1 prolyl hydroxylase protects livers of mice against ischemia/reperfusion injury. Gastroenterology 138(3): 1143-1154 e1141-1142.

Scholz, C. C., Cavadas, M. A., Tambuwala, M. M., Hams, E., Rodriguez, J., Kriegsheim, A., Cotter, P., Bruning, U., Fallon, P. G., Cheong, A., Cummins, E. P. \&Taylor, C. T. (2013). Regulation of IL-1ßinduced NF-KB by hydroxylases links key hypoxic and inflammatory signaling pathways. Proceedings of the National Academy of Sciences of the United States of America 110(46): 1849018495.

Semenza, G. L. (2004). Hydroxylation of HIF-1: oxygen sensing at the molecular level. Physiology 19: 176182.

Semenza, G. L. (2012). Hypoxia-inducible factors: mediators of cancer progression and targets for cancer therapy. Trends in pharmacological sciences 33(4): 207-214.

Stiehl, D. P., Wirthner, R., Köditz, J., Spielmann, P., Camenisch, G. \&Wenger, R. H. (2006). Increased prolyl 4-hydroxylase domain proteins compensate for decreased oxygen levels. Evidence for an autoregulatory oxygen-sensing system. The Journal of biological chemistry 281(33): 2348223491.

Straub, J. A., Lipscomb, E. A., Yoshida, E. S. \&Freeman, R. S. (2003). Induction of SM-20 in PC12 cells leads to increased cytochrome $c$ levels, accumulation of cytochrome $c$ in the cytosol, and caspasedependent cell death. Journal of neurochemistry 85(2): 318-328.

Suda, T., Arai, F. \&Shimmura, S. (2005). Regulation of stem cells in the niche. Cornea 24(8 Suppl): S12S17.

Suri, C., Jones, P. F., Patan, S., Bartunkova, S., Maisonpierre, P. C., Davis, S., Sato, T. N. \&Yancopoulos, G. D. (1996). Requisite role of angiopoietin-1, a ligand for the TIE2 receptor, during embryonic angiogenesis. Cell 87(7): 1171-1180.

Swain, L., Wottawa, M., Hillemann, A., Beneke, A., Odagiri, H., Terada, K., Endo, M., Oike, Y., Farhat, K. \&Katschinski, D. M. (2014). Prolyl-4-hydroxylase domain 3 (PHD3) is a critical terminator for cell survival of macrophages under stress conditions. Journal of leukocyte biology. doi 10.1189/jlb.2HI1013-533R

Tabata, M., Kadomatsu, T., Fukuhara, S., Miyata, K., Ito, Y., Endo, M., Urano, T., Zhu, H. J., Tsukano, H., Tazume, H., Kaikita, K., Miyashita, K., Iwawaki, T., Shimabukuro, M., Sakaguchi, K., Ito, T., Nakagata, N., Yamada, T., Katagiri, H., Kasuga, M., Ando, Y., Ogawa, H., Mochizuki, N., Itoh, H., Suda, T. \&Oike, Y. (2009). Angiopoietin-like protein 2 promotes chronic adipose tissue inflammation and obesity-related systemic insulin resistance. Cell metabolism 10(3): 178-188. 
Takahashi, N., Kuwaki, T., Kiyonaka, S., Numata, T., Kozai, D., Mizuno, Y., Yamamoto, S., Naito, S., Knevels, E., Carmeliet, P., Oga, T., Kaneko, S., Suga, S., Nokami, T., Yoshida, J. \&Mori, Y. (2011). TRPA1 underlies a sensing mechanism for $\mathrm{O}_{2}$. Nature chemical biology 7(10): 701-711.

Takeda, K. \&Fong, G. H. (2007). Prolyl hydroxylase domain 2 protein suppresses hypoxia-induced endothelial cell proliferation. Hypertension 49(1): 178-184.

Takeda, K., Ho, V. C., Takeda, H., Duan, L. J., Nagy, A. \&Fong, G. H. (2006). Placental but not heart defects are associated with elevated hypoxia-inducible factor $\alpha$ levels in mice lacking prolyl hydroxylase domain protein 2. Molecular and cellular biology 26(22): 8336-8346.

Takeda, N., O'Dea, E. L., Doedens, A., Kim, J. W., Weidemann, A., Stockmann, C., Asagiri, M., Simon, M. C., Hoffmann, A. \&Johnson, R. S. (2010). Differential activation and antagonistic function of HIF$\{\alpha\}$ isoforms in macrophages are essential for NO homeostasis. Genes \& development 24(5): $491-$ 501.

Talks, K. L., Turley, H., Gatter, K. C., Maxwell, P. H., Pugh, C. W., Ratcliffe, P. J. \&Harris, A. L. (2000). The expression and distribution of the hypoxia-inducible factors HIF-1 $\alpha$ and HIF-2 $\alpha$ in normal human tissues, cancers, and tumor-associated macrophages. The American journal of pathology 157(2): 411-421.

Tambuwala, M. M., Cummins, E. P., Lenihan, C. R., Kiss, J., Stauch, M., Scholz, C. C., Fraisl, P., Lasitschka, F., Mollenhauer, M., Saunders, S. P., Maxwell, P. H., Carmeliet, P., Fallon, P. G., Schneider, M. \&Taylor, C. T. (2010). Loss of prolyl hydroxylase-1 protects against colitis through reduced epithelial cell apoptosis and increased barrier function. Gastroenterology 139(6): 2093-2101.

Tazume, H., Miyata, K., Tian, Z., Endo, M., Horiguchi, H., Takahashi, O., Horio, E., Tsukano, H., Kadomatsu, T., Nakashima, Y., Kunitomo, R., Kaneko, Y., Moriyama, S., Sakaguchi, H., Okamoto, K., Hara, M., Yoshinaga, T., Yoshimura, K., Aoki, H., Araki, K., Hao, H., Kawasuji, M. \&Oike, Y. (2012). Macrophage-derived angiopoietin-like protein 2 accelerates development of abdominal aortic aneurysm. Arteriosclerosis, thrombosis, and vascular biology 32(6): 1400-1409.

Walmsley, S. R., Chilvers, E. R., Thompson, A. A., Vaughan, K., Marriott, H. M., Parker, L. C., Shaw, G., Parmar, S., Schneider, M., Sabroe, I., Dockrell, D. H., Milo, M., Taylor, C. T., Johnson, R. S., Pugh, C. W., Ratcliffe, P. J., Maxwell, P. H., Carmeliet, P. \&Whyte, M. K. (2011). Prolyl hydroxylase 3 (PHD3) is essential for hypoxic regulation of neutrophilic inflammation in humans and mice. The Journal of clinical investigation 121(3): 1053-1063.

Walmsley, S. R., McGovern, N. N., Whyte, M. K. \&Chilvers, E. R. (2008). The HIF/VHL pathway: from oxygen sensing to innate immunity. American journal of respiratory cell and molecular biology 38(3): 251-255.

Walmsley, S. R., Print, C., Farahi, N., Peyssonnaux, C., Johnson, R. S., Cramer, T., Sobolewski, A., Condliffe, A. M., Cowburn, A. S., Johnson, N. \&Chilvers, E. R. (2005). Hypoxia-induced neutrophil survival is mediated by HIF-1 $\alpha$-dependent NF-KB activity. The Journal of experimental medicine 201(1): 105115.

Wang, F., Shi, S., Zhang, R. \&Hankinson, O. (2006). Identifying target genes of the aryl hydrocarbon receptor nuclear translocator (Arnt) using DNA microarray analysis. Biological chemistry 387(9): 1215-1218.

Wang, G. L., Jiang, B. H., Rue, E. A. \&Semenza, G. L. (1995). Hypoxia-inducible factor 1 is a basic-helixloop-helix-PAS heterodimer regulated by cellular $\mathrm{O}_{2}$ tension. Proceedings of the National Academy of Sciences of the United States of America 92(12): 5510-5514.

Wang, G. L. \&Semenza, G. L. (1993). Characterization of hypoxia-inducible factor 1 and regulation of DNA binding activity by hypoxia. The Journal of biological chemistry 268(29): 21513-21518.

Webster, K. A., Graham, R. M. \&Bishopric, N. H. (2005). BNip3 and signal-specific programmed death in the heart. Journal of molecular and cellular cardiology 38(1): 35-45.

Weischenfeldt, J. \&Porse, B. (2008). Bone Marrow-Derived Macrophages (BMM): Isolation and Applications. CSH protocols 2008: pdb prot5080. 
Wenger, R. H. (2002). Cellular adaptation to hypoxia: $\mathrm{O}_{2}$-sensing protein hydroxylases, hypoxia-inducible transcription factors, and $\mathrm{O}_{2}$-regulated gene expression. FASEB journal 16(10): 1151-1162.

Wong, B. W., Kuchnio, A., Bruning, U. \&Carmeliet, P. (2013). Emerging novel functions of the oxygensensing prolyl hydroxylase domain enzymes. Trends in biochemical sciences 38(1): 3-11.

Wottawa, M., Koditz, J. \&Katschinski, D. M. (2010). Normoxic destabilization of ATF-4 depends on proteasomal degradation. Acta physiologica 198(4): 457-463.

Xie, L., Pi, X., Mishra, A., Fong, G., Peng, J. \&Patterson, C. (2012). PHD3-dependent hydroxylation of HCLK2 promotes the DNA damage response. The Journal of clinical investigation 122(8): $2827-$ 2836.

Xue, J., Li, X., Jiao, S., Wei, Y., Wu, G. \&Fang, J. (2010). Prolyl hydroxylase-3 is down-regulated in colorectal cancer cells and inhibits IKK $\beta$ independent of hydroxylase activity. Gastroenterology 138(2): 606-615.

Yamashita, T., Ohneda, O., Nagano, M., lemitsu, M., Makino, Y., Tanaka, H., Miyauchi, T., Goto, K., Ohneda, K., Fujii-Kuriyama, Y., Poellinger, L. \&Yamamoto, M. (2008). Abnormal heart development and lung remodeling in mice lacking the hypoxia-inducible factor-related basic helix-loop-helix PAS protein NEPAS. Molecular and cellular biology 28(4): 1285-1297.

Yan, B., Jiao, S., Zhang, H. S., Lv, D. D., Xue, J., Fan, L., Wu, G. H. \&Fang, J. (2011). Prolyl hydroxylase domain protein 3 targets Pax2 for destruction. Biochemical and biophysical research communications 409(2): 315-320.

Yancopoulos, G. D., Davis, S., Gale, N. W., Rudge, J. S., Wiegand, S. J. \&Holash, J. (2000). Vascular-specific growth factors and blood vessel formation. Nature 407(6801): 242-248.

Zhang, P., Yao, Q., Lu, L., Li, Y., Chen, P. J. \&Duan, C. (2014). Hypoxia-inducible factor 3 is an oxygendependent transcription activator and regulates a distinct transcriptional response to hypoxia. Cell reports 6(6): 1110-1121.

Zheng, J., Umikawa, M., Cui, C., Li, J., Chen, X., Zhang, C., Huynh, H., Kang, X., Silvany, R., Wan, X., Ye, J., Canto, A. P., Chen, S. H., Wang, H. Y., Ward, E. S. \&Zhang, C. C. (2012). Inhibitory receptors bind ANGPTLs and support blood stem cells and leukaemia development. Nature 485(7400): 656-660.

Zinkernagel, A. S., Johnson, R. S. \&Nizet, V. (2007). Hypoxia inducible factor (HIF) function in innate immunity and infection. Journal of molecular medicine 85(12): 1339-1346. 


\section{Curriculum vitae}

\section{PERSONAL DETAILS}

Name:

LIJA SWAIN

Date of Birth:

16.10.1984

Place of Birth:

Bhubaneswar

Citizenship:

Indian

Contact:

017650965952

EDUCATION AND RESEARCH EXPERIENCE

\begin{tabular}{|l|l|}
\hline Since 07/2011 & $\begin{array}{l}\text { Pursuing PhD under the supervision of Prof. Dr. Dörthe Katschinski at the Georg- } \\
\text { August University Göttingen, thesis on "Prolyl-4-hydroxylase domain 3 (PHD3) is a } \\
\text { critical terminator for cell survival of macrophages under stress conditions". }\end{array}$ \\
\hline $\mathbf{0 9 / 2 0 1 0 - 0 3 / 2 0 1 1}$ & $\begin{array}{l}\text { Master thesis under supervision Prof. Dr. Jens Rettig, at University of Saarland, } \\
\text { Physiology, for my Master thesis on "Functional Characterization of molecular } \\
\text { components involved in exocytotic machinery of cytotoxic T lymphocytes". }\end{array}$ \\
\hline $\mathbf{0 9 / 2 0 0 9 - 0 3 / 2 0 1 1}$ & $\begin{array}{l}\text { Masters in Biomedical Engineering, Furtwangen University, Schwenningen, } \\
\text { Germany }\end{array}$ \\
\hline $\mathbf{1 2 / 2 0 0 8 - 3 1 / 2 0 0 9}$ & $\begin{array}{l}\text { Training under the supervision of Dr Swati Subodh at “The Center for Genomic } \\
\text { Applications" project on "Unique Signature prediction of HIV and HBV genome" }\end{array}$ \\
\hline $\mathbf{0 3 / 2 0 0 8 - 0 8 / 2 0 0 8}$ & $\begin{array}{l}\text { Bachelor's thesis, Institute of Genomics and Integrative Biology, Delhi under the } \\
\text { supervision of Dr. Beena Pillai on MicroRNA and synthetic biology topic "Clonning } \\
\text { and Functional Assay of Drosha in Saccharomyces Cerevisiae". }\end{array}$ \\
\hline $\mathbf{0 8 / 2 0 0 1 - 0 8 / 2 0 0 3}$ & $\begin{array}{l}\text { Bachelors in Technology in Biotechnology, Maharishi Dayanada University } \\
\text { Rohtak, India } \\
\text { College of natural laws, Orissa, India }\end{array}$ \\
\hline
\end{tabular}




\section{POSTER PRESENTATION}

Keystone Symposia conference Cancer and Metabolism/ Advances in Hypoxic Signaling: From Bench to Bedside

Location: Fairmont Banff Springs, Banff, Alberta, Canada

Dates: February 12-17, 2012

HypoxiaNet meeting, Sensing Hypoxia in the Cell and the Organism

Location: Essen, Germany

Date: 20 - 23 September 2012

$92^{\text {nd }}$ Annual Meeting of the German Physiological Society DPG 2013, Location: Heidelberg, Germany

Date: March 2- 5, 2013

Dealing with hypoxia: Regulatory aspects in cells, tissues and organisms

Location: Oulu, Finland

Date: 8 - 12 June 2013

Sensing and Signaling of Hypoxia: Interfaces with Biology and Medicine

Location: Breckenridge, USA

Date: 7-12 January 2014

\section{PUBLICATION}

Swain, L., Wottawa, M., Hillemann, A., Beneke, A., Odagiri, H., Terada, K., Endo, M., Oike, Y., Farhat, K. \&Katschinski, D. M. (2014). Prolyl-4-hydroxylase domain 3 (PHD3) is a critical terminator for cell survival of macrophages under stress conditions. Journal of leukocyte biology doi:10.1189/jlb.2HI1013-533Rjlb.2HI1013-533R 